\title{
Measure Guideline: Hybrid Foundation Insulation Retrofits
}

K. Ueno and J. Lstiburek, Ph.D., P.Eng. Building Science Corporation (BSC) 


\title{
NOTICE
}

This report was prepared as an account of work sponsored by an agency of the United States government. Neither the United States government nor any agency thereof, nor any of their employees, subcontractors, or affiliated partners makes any warranty, express or implied, or assumes any legal liability or responsibility for the accuracy, completeness, or usefulness of any information, apparatus, product, or process disclosed, or represents that its use would not infringe privately owned rights. Reference herein to any specific commercial product, process, or service by trade name, trademark, manufacturer, or otherwise does not necessarily constitute or imply its endorsement, recommendation, or favoring by the United States government or any agency thereof. The views and opinions of authors expressed herein do not necessarily state or reflect those of the United States government or any agency thereof.

Available electronically at http://www.osti.gov/bridge

\author{
Available for a processing fee to U.S. Department of Energy \\ and its contractors, in paper, from: \\ U.S. Department of Energy \\ Office of Scientific and Technical Information \\ P.O. Box 62 \\ Oak Ridge, TN 37831-0062 \\ phone: 865.576 .8401 \\ fax: 865.576.5728 \\ email: mailto:reports@adonis.osti.gov \\ Available for sale to the public, in paper, from: \\ U.S. Department of Commerce \\ National Technical Information Service \\ 5285 Port Royal Road \\ Springfield, VA 22161 \\ phone: 800.553 .6847 \\ fax: 703.605.6900 \\ email: orders@ntis.fedworld.gov \\ online ordering: http://www.ntis.gov/ordering.htm
}




\title{
Measure Guideline: Hybrid Foundation Insulation Retrofits
}

\author{
Prepared for: \\ Building America \\ Building Technologies Program \\ Office of Energy Efficiency and Renewable Energy \\ U.S. Department of Energy
}

Prepared by:

K. Ueno and J. Lstiburek,

Building Science Corporation

30 Forest Street

Somerville, MA 02143

NREL Technical Monitor: Cheryn Engebrecht

Prepared Under Subcontract No.: KNDJ-0-40337-00

May 2012 
[This page left blank] 


\section{Contents}

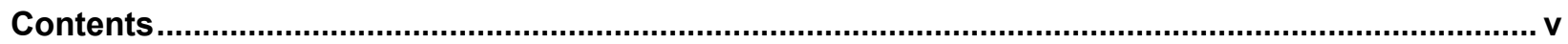

Figures

Tables

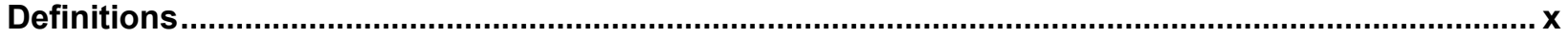

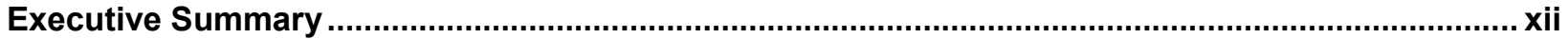

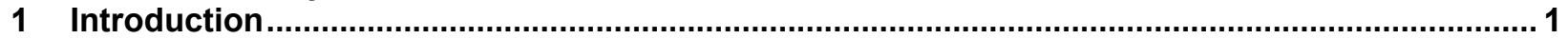

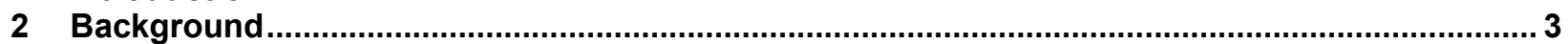

2.1 Basement Insulation Energy Impacts and Insulation Location...................................................... 3

2.2 Foundation Wall Insulation Moisture Accumulation and Damage Risks..................................... 6

2.3 Foundation Freezing Issues due to Insulation Retrofit ............................................................ 9

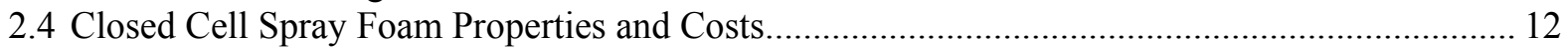

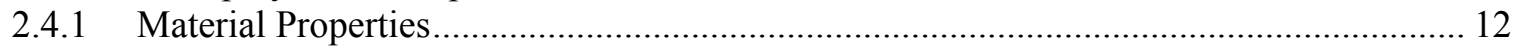

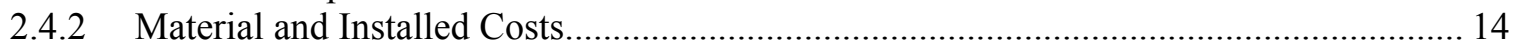

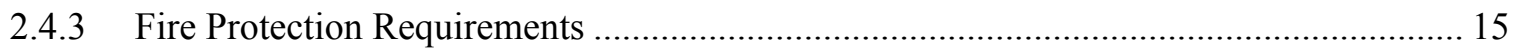

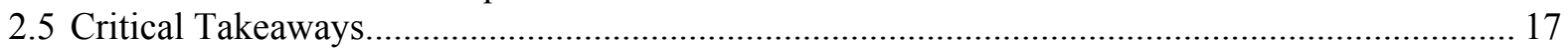

3 Previous Work

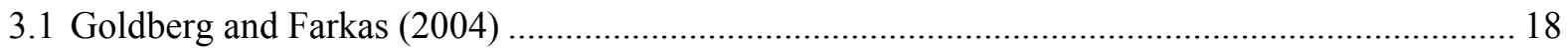

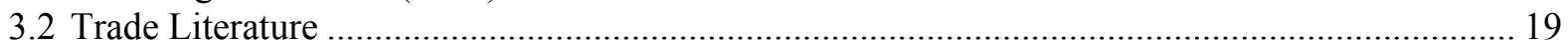

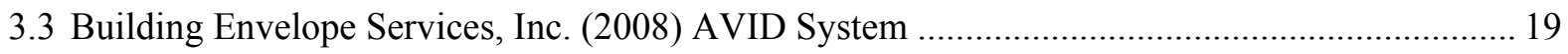

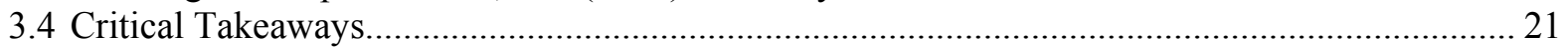

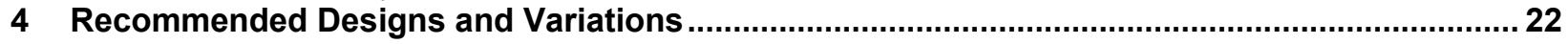

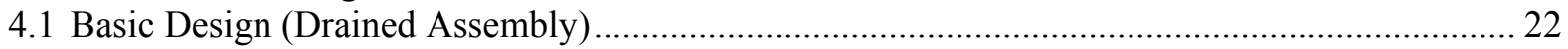

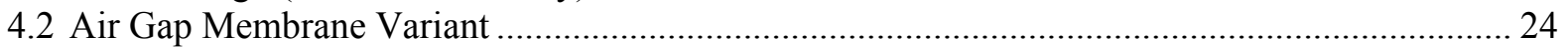

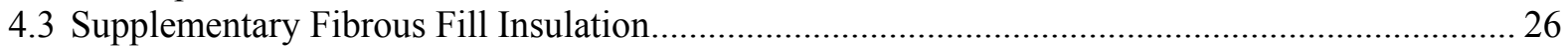

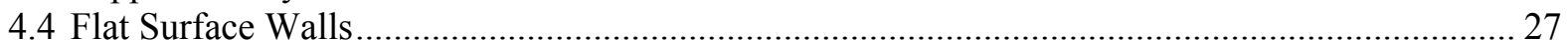

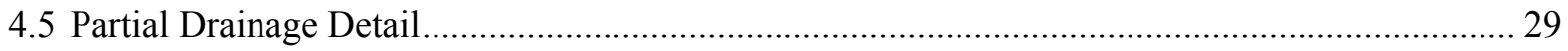

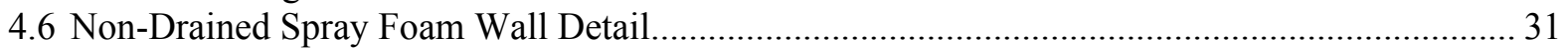

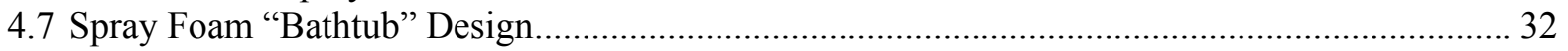

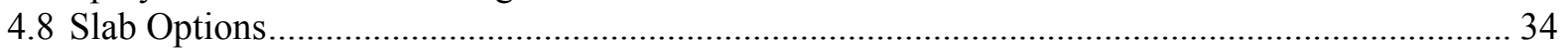

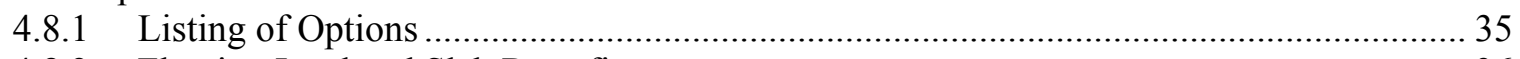

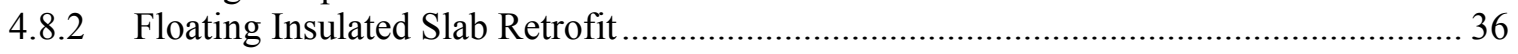

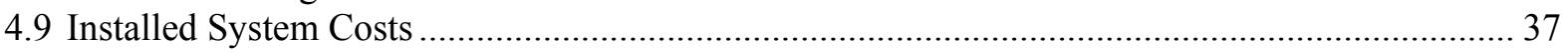

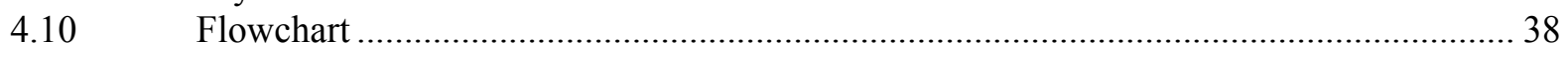

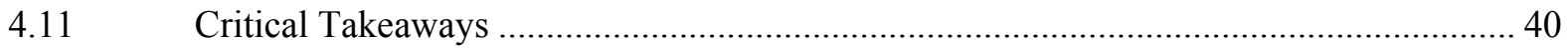

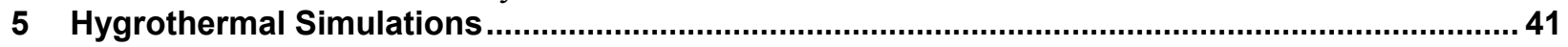

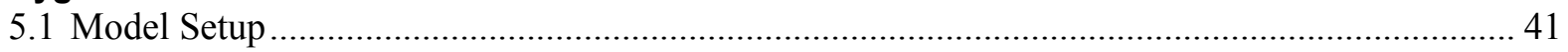

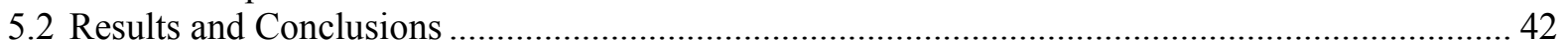

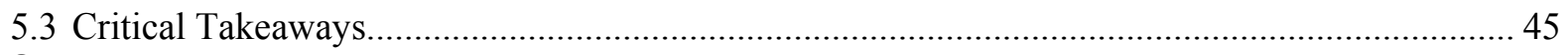

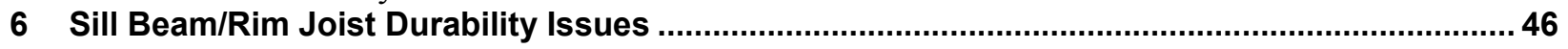

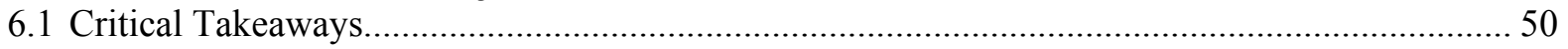

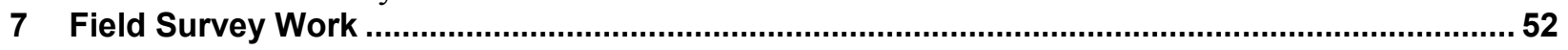

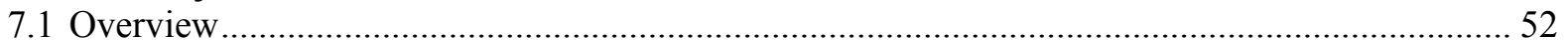

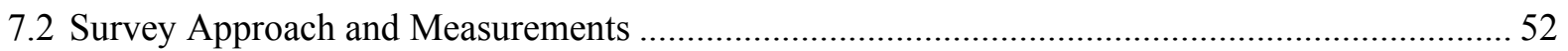

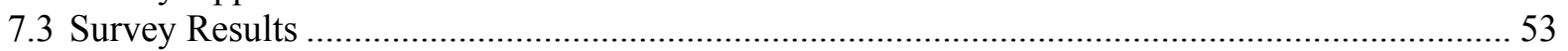

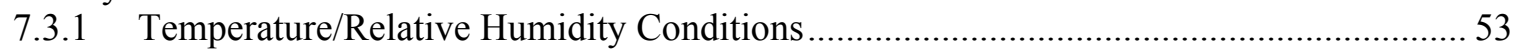

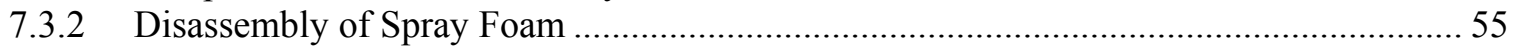

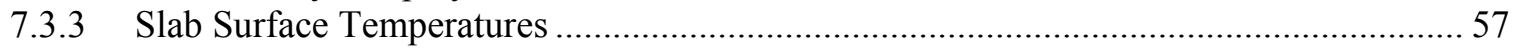

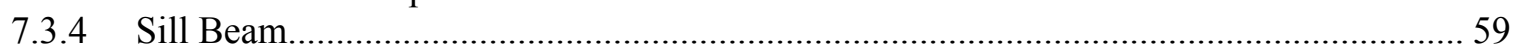

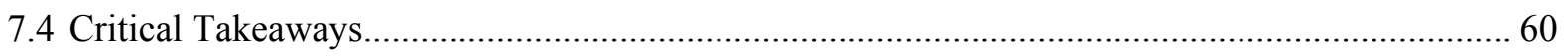

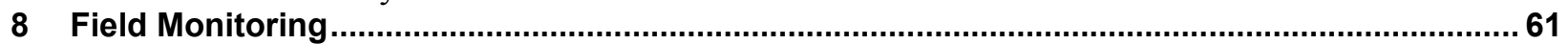




\section{u.s. DEPARTMENT OF | Energy Efficiency \& \\ -NERC Renewable Energy}

8.1 Field Monitoring Site

8.2 Comparison Data ........

62

9 Conclusions and Further Work

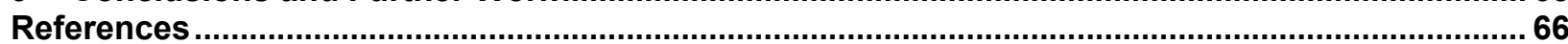




\section{Figures}

Figure 1. Active seepage through cast concrete (L); water damage concealed behind finishes (R). 1 Figure 2. Choices for insulation location in retrofits (adapted from Lstiburek 2006)........................ 2 Figure 3. Arlington, MA Duplex basement ceiling spray foam, and nulled air leakage testing .......... 4 Figure 4. Basement ceiling insulation and air sealing plan and completed image..........................5 Figure 5. Ground water accumulation behind impermeable basement insulation systems (Lstiburek 2006)

Figure 6. Air transported moisture issues (Lstiburek 2006), and interstitial condensation potentials7 Figure 7. Construction moisture accumulation behind impermeable basement insulation systems

(polyethylene-faced fiberglass) (Lstiburek 2006).

Figure 8. Capillary uptake of water through footing-to-foundation-wall connection........................... 8

Figure 9. Basement slab heaving in unheated basement (Lstiburek 2010b) .................................... 9

Figure 10. Frost Expansion. Freezing of frost-susceptible soil behind walls causing thrust

perpendicular to the freezing front (Lstiburek 2010b) ............................................................... 9

Figure 11. Extreme frost depth penetration map (Lstiburek 2010b) ............................................ 10

Figure 12. Uninsulated (L) and insulated (R) rubble basement comparison (Lstiburek 2010b) ........ 11

Figure 13. Exterior "wing" insulation (L), exterior water control measures (M), and drainage

through the foundation wall (R) (Lstiburek 2010b) ............................................................... 12

Figure 14. Insulation material costs (no installation), in $\$ / s f \cdot R$ value ............................................ 15

Figure 15. AVID installation (๑ 2011 by Building Envelope Services; reprinted with permission) .. 20

Figure 16. AVID diagram (๑ 2011 by Building Envelope Services; reprinted with permission) ........ 20

Figure 17. Interior drainage-renovation, showing various foundation wall materials.................... 22

Figure 18. Overview of Westford House/Barn, existing foundation conditions (Lstiburek 2010a) .. 23

Figure 19. Sill beam lift and slab insulation and drainage (Lstiburek 2010a)................................ 23

Figure 20. Self-adhered membrane and spray foam installation (Lstiburek 2010a) ......................... 24

Figure 21. Air gap membrane under spray foam installation; 4' basement slab edge insulation .... 24

Figure 22. Spray foam slab edge insulation detail; completed installation of spray foam ...............25

Figure 23. Air gap membrane venting to underside of beam (L); retrofitted detail (R).....................25

Figure 24. Spray foam and fibrous fill (netted cellulose) foundation insulation assembly .............. 26

Figure 25. Basement with spray foam (L); and added cellulose in framed wall (R).........................26

Figure 26. Interior drainage; new or retrofit construction (non-rubble walls); foil-faced foam ........ 27

Figure 27. Interior drainage; new or retrofit construction (non-rubble walls); foam covered with

gypsum board.

Figure 28. Drainage mat sub-slab detail; terminates at slab perimeter to collect bulk water...........29

Figure 29. Basement slab insulation, and edge drainage mat detail continuing under slab............. 30

Figure 30. Drainage mat penetration at chimney; retrofit sealing of drainage mat .......................... 30

Figure 31. ccSPF wall insulation with no drainage layer (dry basement); no slab insulation .......... 31

Figure 32. Modification of existing partitions (๑ 2011 by Byggmeister; reprinted with permission)32

Figure 33. Spray foam applied to walls and slab (๑ 2011 by Byggmeister; reprinted with

permission)

Figure 34. Casting of slab; wall framing (๑ 2011 by Byggmeister; reprinted with permission) ........ 33

Figure 35. Storage use basement slab insulation/moisture control retrofit; cement board surface 36

Figure 36. Use of air gap membrane and insulation as a "wet slab" retrofit..................................37

Figure 37. Flowchart for interior foundation insulation options and water control........................... 39

Figure 38. WUFI insulated model setup, showing layers and monitor positions............................. 42

Figure 39. Moisture flux through concrete (and insulation), $\mathrm{kg} / \mathrm{m}^{2} \cdot$ year........................................ 43

Figure 40. Concrete layer moisture content, $\mathrm{kg} / \mathrm{m}^{3}$, pre- and post-insulation ................................ 43

Figure 41. Parging and mortar erosion due to capillarity (Lstiburek 2007) .................................... 44

Figure 42. Sill lift and pre-retrofit sill beam condition at Bedford Farmhouse .................................. 46

Figure 43. Damaged sill beams from Bedford Farmhouse ................................................................. 47

Figure 44. Sill beam detail at Bedford Farmhouse deep energy retrofit project ...............................47

Figure 45. Pre- and post-retrofit basement wall and sill beam temperatures...................................... 48

Figure 46. Sill beam insulated with vapor-permeable mineral fiber insulation overclad ..................50

Figure 47. Westford House/Barn recladding and sill beam inspection ..............................................5 50 
Figure 48. Measurement of T/RH conditions behind ccSPF insulation, Somerville Office

Figure 49. Psychrometric comparison of survey site conditions (basement and exterior to foam) 54

Figure 50. Boston area monthly temperature, dewpoint, and precipitation, $2010-2011 \ldots \ldots . . . . . . . . . . .55$

Figure 51. Test port cut into wall ccSPF, Bedford Farmhouse Renovation..................................... 56

Figure 52. Test port cut into wall ccSPF, Somerville Office ................................................................56

Figure 53. Air gap behind membrane; demonstration of airflow behind foam, Westford Barn/House56

Figure 54. Slab temperature at perimeter, Westford Barn/House

Figure 55. Slab temperature at footing penetrations, Westford Barn/House .................................. 58

Figure 56. Sump pit temperatures, Concord House ...................................................................... 58

Figure 57. Slab temperature underneath carpet, Concord House ................................................... 59

Figure 58. Slab temperatures under filled cardboard box, Somerville Office .................................... 59

Figure 59. Sill beam moisture content measurement, Somerville Office ...........................................6 60

Figure 60. Exterior view of St. Agatha site; completed basement ccSPF retrofit ............................61

Figure 61. ( $L$ to R) Pre-retrofit basement; interior framing; spray foam application ........................61

Figure 62. Overview and close-up of instrumentation in ccSPF retrofit basement .........................62

Figure 63. Infrared images of basement wall in wintertime (February) conditions..........................62

Figure 64. Sensor locations and types in basement wall monitoring (Ueno 2007)..........................63

Figure 65. Concrete-insulation interface temperature, monitored vs. simulation (Ueno 2007)........ 64

Unless otherwise noted, all figures were created by Building Science Corporation. 


\section{Tables}

Table 2. Available Installed Cost Information on Foundation Retrofit Options................................. 37

Table 3. List of Boundary Conditions for WUFI Foundation Simulations ........................................... 41

Table 4. Boundary Conditions for Foundation THERM Simulations ….......................................... 48

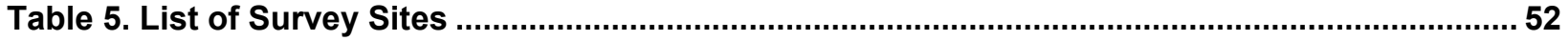

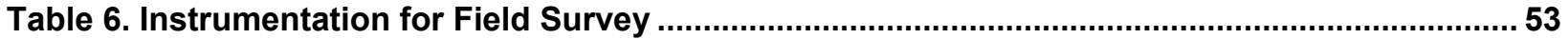

Table 7. Air Temperature/Relative Humidity, Slab, and Sump Pit Conditions................................. 57

Unless otherwise noted, all tables were created by Building Science Corporation. 


\section{Definitions}

$\mathrm{ACH}$

ACH 50

ASHRAE

ASTM

BA

BSC

ccSPF

CFM

CFM 50

CMU

DER

DOE

DWV

EPS

FT

HVAC

IAQ

ICC

IRC

NFPA

NREL

ocSPF
Air changes per hour

Air changes per hour at 50 Pascal test pressure

American Society of Heating, Refrigeration, and Air Conditioning Engineers

American Society for Testing and Materials

Building America Program. More information about BA can be found at www.buildingamerica.gov

Building Science Corporation.

Closed cell Spray Polyurethane Foam

Cubic feet per minute

Cubic feet per minute at 50 Pascal test pressure

Concrete masonry unit

Deep Energy Retrofit

U.S. Department of Energy

Drain, waste, vent

Expanded polystyrene

Freeze-thaw

Heating, ventilation, and air conditioning

Indoor air quality

International Code Council

International Residential Code

National Fire Protection Association

National Renewable Energy Laboratory.

Open cell Spray Polyurethane Foam 
$\mathrm{Pa}$

PCF

RH

SPF

WUFI

XPS
Pascal (unit of pressure)

Pounds per cubic foot

Relative humidity

Spray Polyurethane Foam

Wärme- Und Feuchtetransport Instationär

(http://www.wufi.de/)

Extruded polystyrene 


\section{Executive Summary}

Basements can account for up to one quarter of the typical energy consumption in a house. Therefore, insulating foundations is a critical measure for achieving high performance buildings. This is important in both new construction and retrofits of existing buildings.

The fundamental problems and "best practice solutions" for moisture-safe basement insulation have been well established. However, many foundations are damp (either due to bulk water or capillary "wicking" of moisture) or of a type of construction that is not easy or straightforward to insulate (such as rubble foundations). Damp foundation repair methods can be "leveraged" to provide energy efficiency benefits. An example of this "hybrid" approach is spray foam insulation, which can be an effective means of liquid phase water control (leaking basement), vapor phase water control (diffusion and air leakage transported condensation) as well as an effective insulation.

One common question is whether or not to include the basement in the conditioned space, which determines the insulation location (at the basement ceiling or walls). Field experience shows that insulating and air sealing at the floor/ceiling plane is likely to result in poor overall airtightness: this is not acceptable for high performance housing. Therefore, including the basement within the conditioned space is the recommended approach, providing insulation at the foundation walls and possibly the floor slab.

The hygrothermal behavior of foundation wall insulation has been covered in the literature. Moisture damage risks when insulating below-grade walls include bulk water, flooding, ground moisture, wintertime and summertime interstitial condensation, soil gas, construction moisture, and capillary rise at footings.

One reported objection to insulation of foundations is the perceived risk of freezing-based damage to the foundation, caused by reduced heat loss to the ground: specifically, frost heaving of the foundation wall, or adfreezing damage. Overall, the research literature indicates that soilfreezing behavior results in minimal likelihood of damage in heated (even insulated) basements.

A variety of recommended designs and variations for retrofit hybrid assemblies are shown in this report. Variations include closed cell spray foam (ccSPF) with membrane waterproofing or air gap membrane drainage layers, rigid board foam insulation at flat walls (cast concrete or CMU block), a "partial drainage" detail making use of the bulk water drainage that occurs through the field of a rubble stone wall, and non-drained spray foam assemblies (including slab insulation). Note that in all of these designs, the basement will become more airtight. Therefore, combustion safety measures must be addressed for any fuel-burning appliance located in the basement/crawl space.

Hygrothermal simulations were run to quantify the reduction of moisture entry into the basement due to this interior retrofit. A simplified, one-dimensional model showed a substantial reduction in moisture movement through the retrofitted foundation, which means that the moisture/humidity contribution of the foundation drops to negligible levels. 
There are durability concerns associated with the use of spray foam at the sill beam/rim joist: the beam is colder (and therefore potentially wetter) than its pre-retrofit condition. Energy and airflow are not available to assist in drying. In addition, the use of low-permeability ccSPF on the interior greatly reduces drying to the interior. Given that damage is often seen in sill beams in pre-retrofit conditions, further study is recommended to better understand the relative contributions of various risk factors, and the effectiveness of mitigation techniques.

Several basements with these interior insulation and drainage systems were available to the researchers: a field survey of these sites was conducted. The relative humidity behind the ccSPF was high in all cases, therefore, an effective air barrier between the hidden airspace and the interior is critical. The ccSPF layer functions as the air barrier; a rubble wall is not an acceptable air barrier without additional detailing (e.g., parging). There was no sign of any damage due to exterior masonry freeze-thaw issues, frost heaving, or adfreezing. There was no indication of moisture erosion damage or high moisture contents in the sill beam, albeit with a limited survey.

One further component of this project is the field monitoring of a basement insulated with interior closed cell spray foam. Current analysis shows the phenomenon of vertical wicking of heat from the earth around the foundation up into the foundation wall. This is consistent with findings by Ueno (2007).

Overall, the use of closed cell spray foam as a method of damp foundation rehabilitation and insulation should be considered an effective and mature technology, with an extensive track record in a variety of applications. There are thousands of implementations of various types of these systems, without reports of endemic failures. It is reasonable to consider this system ready for mass implementation in retrofit projects. 


\section{Introduction}

Basements account for up to one quarter of the typical energy consumption in a house (Crocker 1974). Therefore, insulating foundations is a critical measure for achieving high performance buildings. This is important in both new construction and retrofits of existing buildings. In retrofits, the weatherization industry has often concentrated their efforts on the above-grade portions of the enclosure (such as sidewall cavity fill insulation, attic insulation, and airtightness measures), without addressing the foundation.

The fundamental problems and "best practice solutions" for moisture-safe basement wall insulation have been well established: they are described by (among others) Lstiburek (2006) and Swinton \& Kesik (2005). Some key requirements include an insulation material that is not moisture sensitive and an assembly that prevents interior air from contacting the insulation-tofoundation wall interface. Building America-funded research on the performance of various interior basement insulation systems has been conducted by Zuluaga et al. (2004) and Ueno (2007). In addition to reinforcing best practice solutions listed above, they showed the risks of using vapor-impermeable interior side layers in below-grade wall assemblies. This last issue was also corroborated by Hales et al. (2010).

However, many foundations are damp (either due to bulk water or capillary "wicking" of moisture) or of a type of construction that is not easy or straightforward to insulate (such as rubble foundations). Bulk water leakage can cause severe damage to improperly designed interior insulation assemblies (Figure 1). Assemblies that provide insulation (and interior finishes, if desired) and control bulk water leakage are a valuable potential retrofit component.
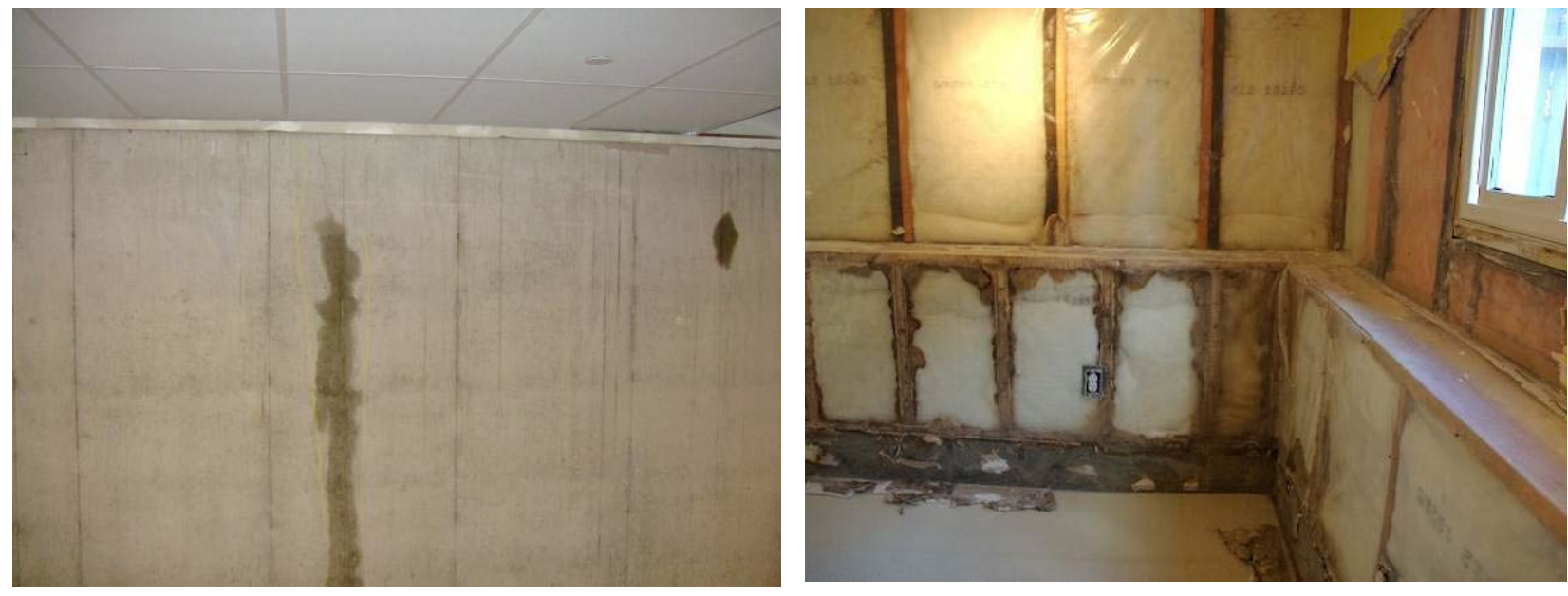

Figure 1. Active seepage through cast concrete (L); water damage concealed behind finishes (R)

Foundation insulation can be accomplished by several methods, as discussed in generic terms by Lstiburek (2006), and shown in Figure 2. These methods of insulation include:

- Interior: most common, least expensive, most moisture problems

- Exterior: best location from physics perspective, practical problems with protection, thermal bridging and insects 
- Middle: most expensive, fewest moisture and insect problems, but is the most difficult to construct

- Both sides: similar problems to the exterior insulation approach with the additional cost of the interior layer.

However, in a retrofit case, options are limited: insulating in the middle and both sides are not reasonable choices for an existing wall. Exterior insulation is possible; it is also an excellent solution in terms of building physics (Swinton et al. 2000), and the ability to retrofit exterior water control measures. However, it is often eliminated from consideration due to the cost and logistical difficulty of exterior excavation.

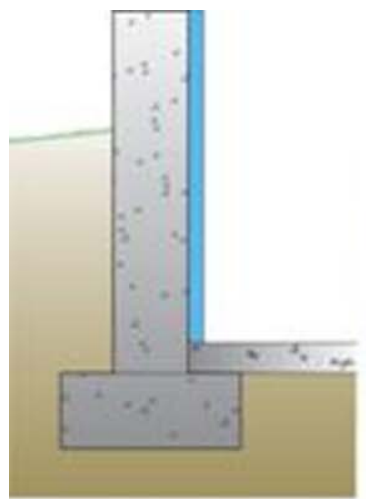

Internally Insulated Basement

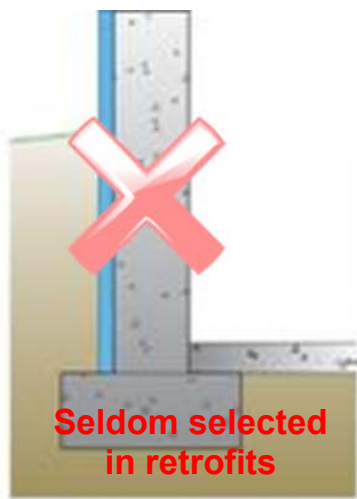

Externally Insulated Basement

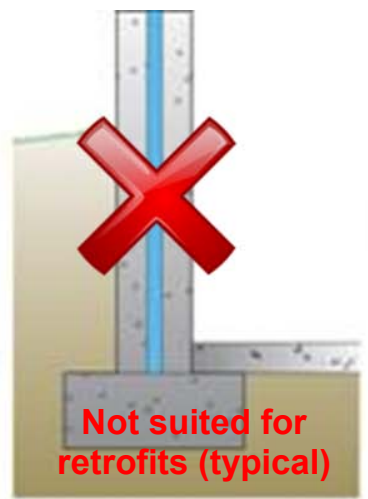

Basement Insulated in the Middle

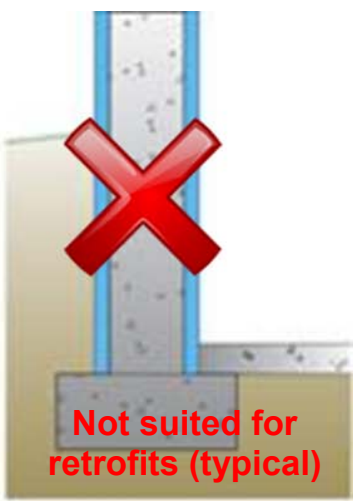

Basement Insulated Both Externally and Internally

Figure 2. Choices for insulation location in retrofits (adapted from Lstiburek 2006)

The research team believes that many methods of damp foundation repair can be "leveraged" to provide energy efficiency benefits. An example of this "hybrid" approach is spray foam insulation, which can be an effective means of liquid phase water control (leaking basement), vapor phase water control (diffusion and air leakage transported condensation) as well as an effective insulation. These methods are described by Lstiburek (2010a, 2010b). Numerous hybrid approaches can potentially deliver high levels of insulation economically, while solving many vexing moisture problems.

Of course, foundation bulk water should be controlled by exterior means if possible before resorting to interior drainage systems. This topic is covered in the BSC Research Report 1015 "Bulk Water Control Methods for Foundations" (Ueno \& Lstiburek 2010).

Note that the term "basement" is often applied generically in this report. All of the assemblies described here could be used in crawl space applications, assuming similar foundation construction and exterior characteristics. 


\section{Background}

\subsection{Basement Insulation Energy Impacts and Insulation Location}

Heat losses through the basement have been estimated in the range of $10 \%-30 \%$ of a house's total heat loss (BETT 1985a, Beausoleil-Morrison 1997, Swinton \& Kesik 2005), and controlling this heat loss can significantly reduce overall space conditioning energy use. This is especially true in modern energy efficient houses, which reduce the heat loss through the above-grade portion of the enclosure by measures such as better-insulated roofs, windows, walls, and increased airtightness. These measures would therefore increase the relative contribution of an uninsulated basement. This trend was already noted by the mid 1970's (Crocker 1974); some suggested that this weatherization of the above-grade enclosure increases the contribution of an uninsulated basement to 50\% of the total heating load (Carmody et al. 1991). Of course, the actual heat loss through the below-grade structure is a function of the local soil conductivity, climate, and interior conditions of the basement.

The R-value of an uninsulated concrete wall is very low. Assuming conductivity values of 10 to $18 \mathrm{Btu} \cdot \mathrm{in} / \mathrm{h} \cdot \mathrm{ft}^{2} \cdot{ }^{\circ} \mathrm{F}(1.4$ to $2.6 \mathrm{~W} / \mathrm{m} \cdot \mathrm{K})$, a typical 8 " $(0.2 \mathrm{~m})$ thick wall is in the range of $\mathrm{R}-0.44$ to R-0.82 (RSI $0.08-0.15$ ). The conductivity of concrete is higher than typical soil conductivities of 5.6-6.3 Btu $\cdot \mathrm{in} / \mathrm{h} \cdot \mathrm{ft}^{2} \cdot{ }^{\circ} \mathrm{F}(0.8-0.9 \mathrm{~W} / \mathrm{m} \cdot \mathrm{K})$, and is comparable to the higher conductivity/wetter soils. One implication of the high conductivity of concrete is that insulation can have a tremendous effect: a typical code minimum of R-10 (RSI 1.8) is a tenfold increase in insulating value.

One common question is whether or not to include the basement in the conditioned space, which determines the insulation location:

- At the basement ceiling (excludes basement from conditioned space)

- At the basement walls, and possibly also the floor slab (includes basement in conditioned space).

Insulating at the basement ceiling with fibrous cavity insulation is a common choice in the Northeast region of the United States. However, wall insulation (i.e., including the basement in the conditioned space) is a better choice overall for energy performance, for several reasons:

- The floor/ceiling assembly between the basement and the first floor is not an effective air barrier, due to mechanical penetrations (plumbing, electrical, HVAC, masonry chimney), and a general lack of air barrier detailing (e.g., weatherstripped doors to basement, etc.). Therefore, air-permeable insulation installed in the floor/ceiling assembly is bypassed and relatively ineffective.

- Mechanical equipment is commonly located in the basement, including space conditioning systems and domestic hot water equipment. In a heating-dominated climate, recovering the losses from this equipment (instead of leaving it in an unconditioned zone) improves energy performance. This is particularly true if ductwork and HVAC systems are located in this space, as ductwork (and air handler) leakage can be a significant source of thermal losses. 
- Including the basement within the conditioned space increases the amount of available conditioned space, even if it is only used for conditioned storage and auxiliary space.

Two recent deep energy retrofit projects chose to insulate at the floor/ceiling level. Reasons for this included unwillingness to retrofit combustion safety measures to existing heating equipment, unwillingness to address existing masonry walls, and perceived low value of basement space.

One such project was discussed in Ueno (2010) (the Arlington, MA "Duplex" project). The floor/ceiling retrofit involved the removal of basement ceiling finishes and application of 0.5 pounds/cubic foot polyurethane spray foam (ocSPF) in the joist cavities (see Figure 3) as insulation and an air barrier. The existing atmospheric boilers were retained in the basement, and the door from the first floor to the basement was weatherstripped.

Nulled or guarded blower door air leakage testing was conducted, using multiple blower doors to equalize pressures between the basement and above-grade zones. Afterwards, unguarded tests were run on individual zones (with the adjacent zones open to the exterior); the difference between tests can be used to calculate leakage to adjacent zones. These methods are commonly used in testing multifamily or multizone buildings, and in particular, airtightness of portions of an enclosure (Genge 2009).
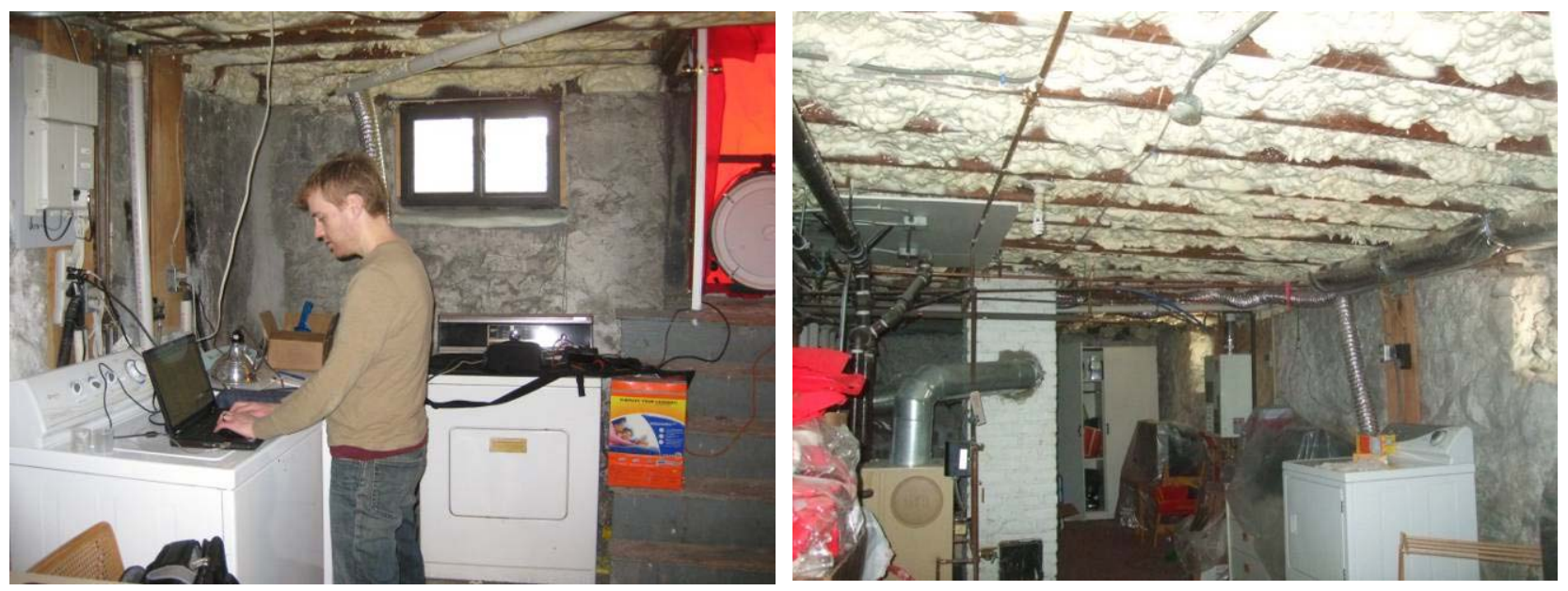

Figure 3. Arlington, MA, duplex basement ceiling spray foam, and nulled air leakage testing

The tests revealed that despite these air sealing efforts, the basement was still well-connected to the above grade space, and that the overall air leakage was higher than targeted, largely due to leakage through the basement ceiling plane. The normalized overall air leakage results were 4.6 ACH50, or 0.33 CFM 50 per square foot of building enclosure, despite extensive retrofitting of all components of the building. Of the total building leakage (2129 CFM 50), over half ( 1100 CFM 50) was due to leakage through the ceiling/floor plane. Localization of leakage did not reveal any dominant leakage points, but unsealed mechanical penetrations, the stairwell (both walls and doors), doubled framing members, and the properties of $0.5 \mathrm{PCF}\left(8 \mathrm{~kg} / \mathrm{m}^{3}\right)$ foam were suspected as weak points.

A similar deep energy retrofit project also attempted to exclude the basement from the conditioned space. The floor-ceiling retrofit assembly included high-density spray foam for air barrier detailing, blown-in cellulose in joist bays, and foil-faced polyisocyanurate attached to the 
underside of the framing (see Figure 4). Again, the results were worse than expected, with normalized leakage at $8.5 \mathrm{ACH} 50$ or $0.54 \mathrm{CFM} 50$ per square foot of building enclosure. Again, leakage through the floor/ceiling assembly comprised roughly half of the total leakage of the building (1740 CFM 50 out of 3590 CFM 50). This leakage was ascribed to the presence of ductwork systems in the basement, mechanical penetrations, and connections to the above-grade via two stairwells.
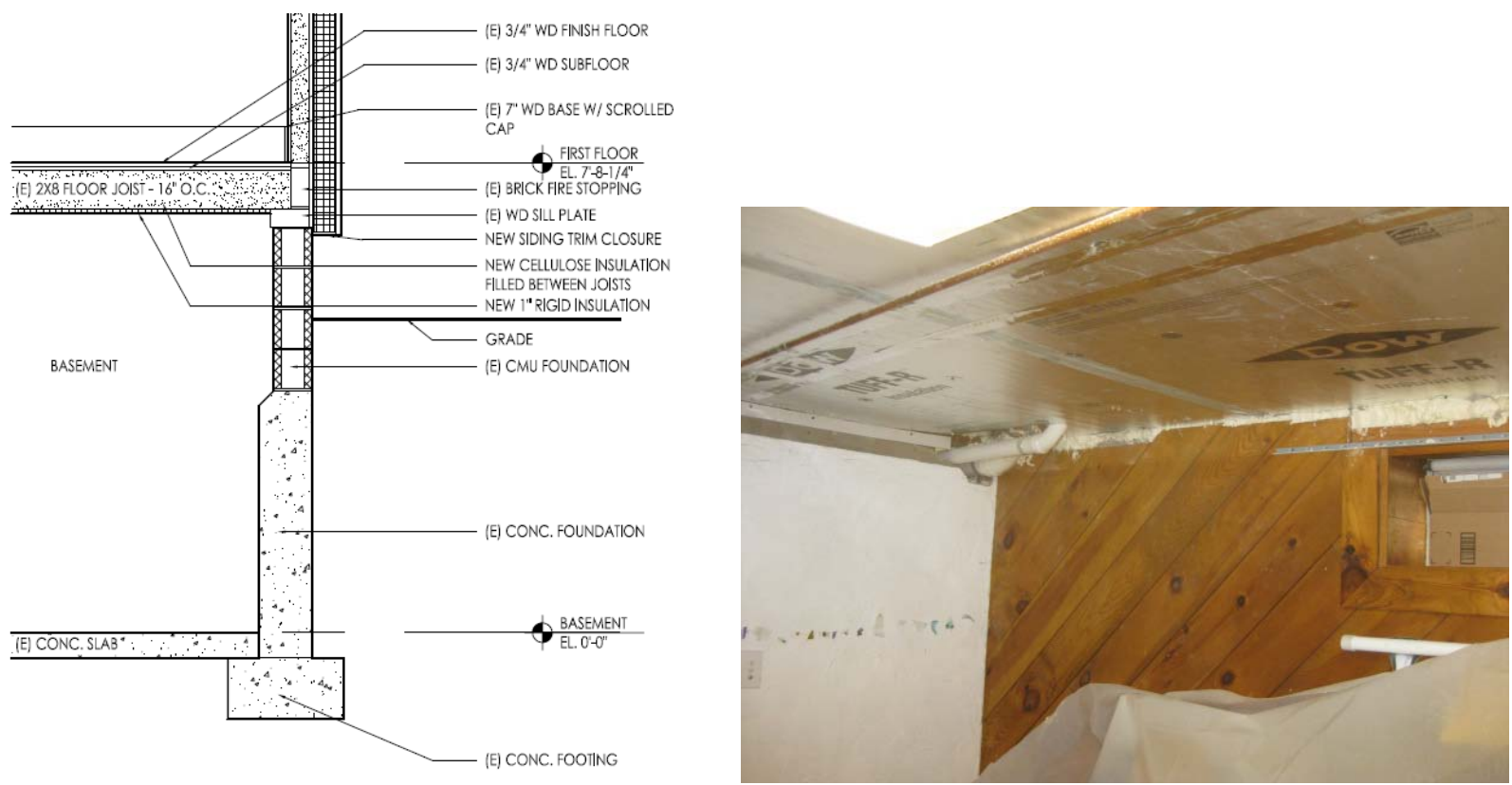

Figure 4. Basement ceiling insulation and air sealing plan and completed image

Field experience (including these recent test cases) shows that insulating and air sealing at the floor/ceiling plane is likely to result in poor overall airtightness, which is not acceptable for high performance housing. For comparison, typical targets for high performance retrofits would be close to 1-2 ACH 50 or 0.10-0.20 CFM 50 per square foot of building enclosure. Therefore, including the basement within the conditioned space is the recommended approach, providing insulation at the foundation walls and possibly the floor slab. However, there are hygrothermal issues to be considered: these enclosure elements have moisture-related issues that can degrade insulated assemblies. As discussed previously, bulk water leakage into the insulation and finish assembly has the potential to cause severe and rapid damage.

In crawl space foundations with no mechanical equipment (including ductwork) or stairwell connection, the arguments to bring the foundation into the conditioned space are less strong. Flood-prone regions, in particular, are often unsuited for conditioned crawl spaces. Alternate details, such as ccSPF on the underside of the floor assembly, encasing the framing, can provide good performance, as discussed by Lstiburek (2008). 


\subsection{Foundation Wall Insulation Moisture Accumulation and Damage Risks}

The hygrothermal behavior of foundation wall insulation has been covered in the literature. Some resources include Cheple \& Huelman (2001), Swinton \& Kesik (2005), Lstiburek (2006), and Ueno (2007). Following are summaries of risks:

Bulk water: Due to their below-grade location, foundation walls have the potential to suffer from bulk water leakage from exterior soil (Figure 5). High risk factors include poorly drained soil, water concentrations adjacent to the building, and/or sub-grade drainage systems that are insufficient, in poor condition, or nonexistent. Further information can be found in the BSC report, "Bulk Water Control Methods for Foundations" (Ueno and Lstiburek 2010). Bulk water leakage has the potential to cause the greatest amount of damage to interior assemblies in the shortest amount of time. Moisture that is trapped behind interior insulation systems has the potential to damage the insulation material, as well as cause indoor air quality issues.

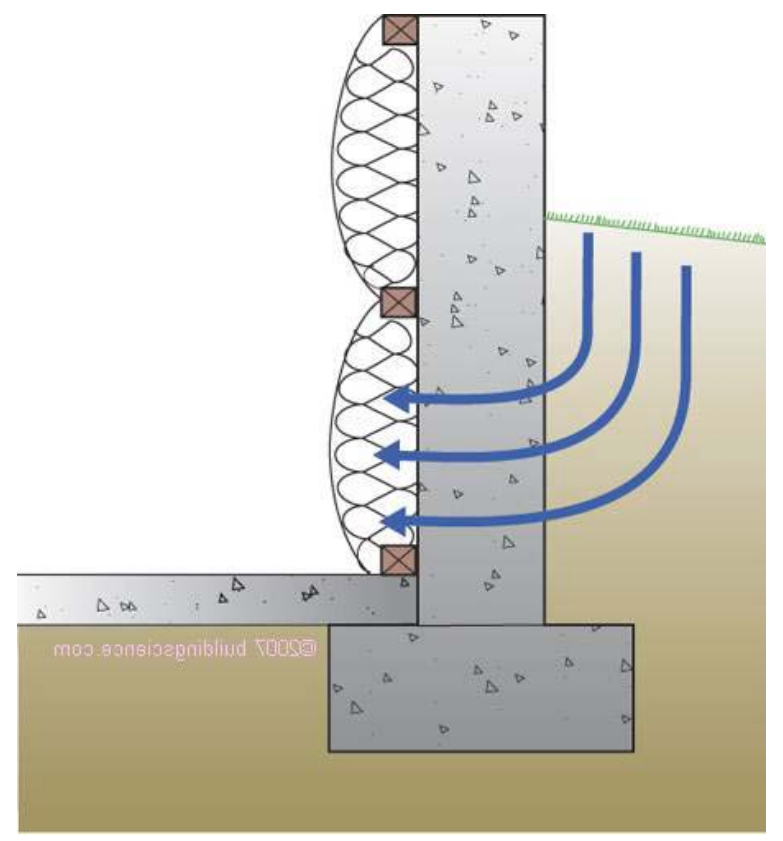

Figure 5. Ground water accumulation behind impermeable basement insulation systems (Lstiburek 2006)

Flooding: In a similar vein, flooding - either from exterior or interior sources (such as plumbing leaks) — can potentially add moisture to the foundation. Foundations should be designed assuming that flooding might occur during their lifetime. Moisture-sensitive materials subjected to flooding will need to be removed and disposed of, or dried in place.

Ground moisture: Note that even without the presence of bulk water leakage, the soil exterior boundary conditions for a foundation wall are cool $\left(50^{\circ}-65^{\circ} \mathrm{F} / 10^{\circ}-15^{\circ} \mathrm{C}\right)$ typically at the lower portions of the wall; Hutcheon and Handegord 1995) and always at 100\% RH. This can be an additional source of moisture, particularly if exterior dampproofing methods have not been used. This is a common situation in many of the existing foundations in retrofit projects.

Wintertime interstitial condensation: The interior insulation layer is typically not airtight and does not prevent interior air from condensing on concrete foundation walls (Figure 6, left). The 
above-grade portion of the foundation wall is similar to above-grade walls: the concrete surface will be cold in wintertime, resulting in condensation risks (and thus mold/IAQ issues). A typical wintertime temperature gradient for the assembly is shown in Figure 6 (below).

Springtime interstitial condensation: Air leakage from the interior can also cause condensation inside the assembly during warm weather. The ground around the foundation stays cool in warmer weather, so the foundation wall (especially the lower portion) has a risk of condensing moisture from interior air, especially in the springtime, as ambient air moisture levels increase.

Soil gas: Another potential source of condensation is that soil gas can enter the assembly at concrete slab-perimeter wall interface, which is often left unsealed (Figure 6, left). This joint must be sealed to exclude soil gases - not only for these condensation concerns, but for IAQ reasons.
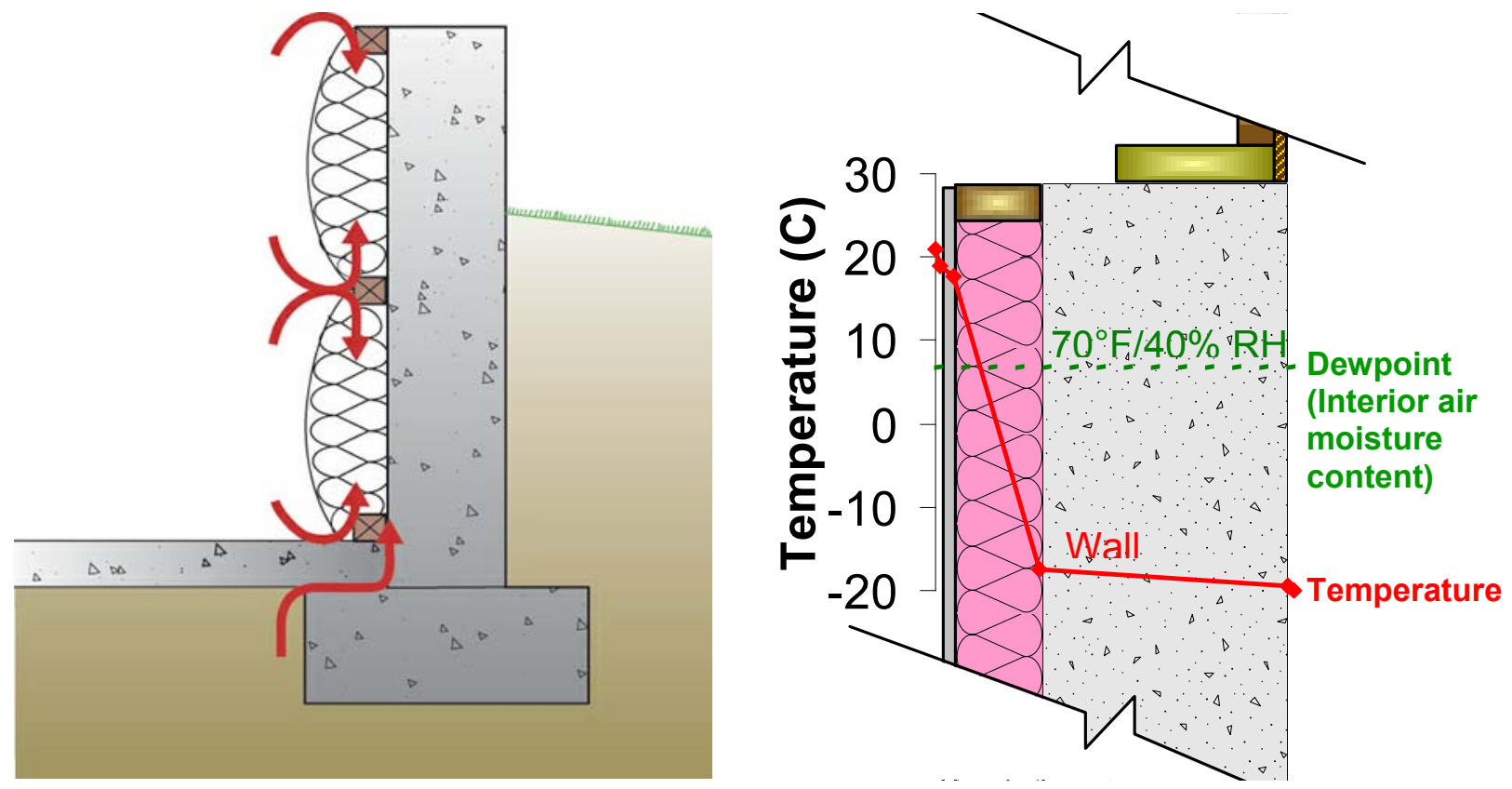

Figure 6. Air transported moisture issues (Lstiburek 2006), and interstitial condensation potentials

Construction moisture: There is a tremendous amount of water trapped in freshly placed concrete - several thousand pounds in a typical foundation. When a freshly cast foundation is insulated with a vapor impermeable insulation material, it cannot dry to interior; any moisturesensitive materials within the assembly (e.g., fiberglass insulation, wood battens) will be trapped in contact with moisture (Figure 7).

There are even risks associated with retrofit situations that nominally have been drying for long periods. For instance, wetting events (such as floods) through the life of the foundation could have resulted in wetting of the concrete wall. Furthermore, many older foundations were built without exterior dampproofing, and therefore have been continuously loaded with soil-sourced moisture. 


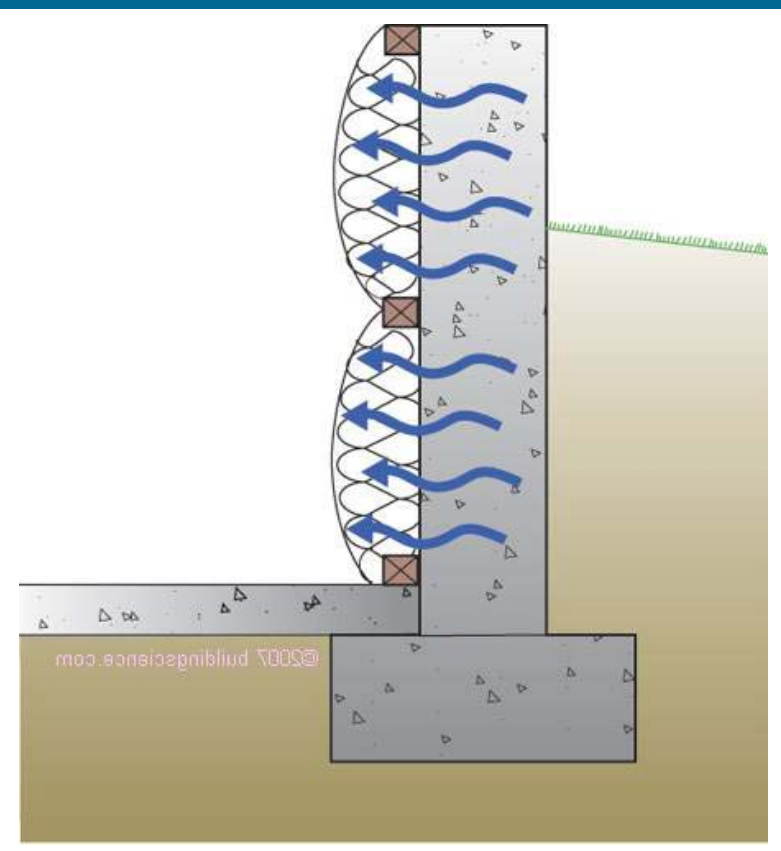

Figure 7. Construction moisture accumulation behind impermeable basement insulation systems (polyethylene-faced fiberglass) (Lstiburek 2006)

Capillary rise at footings: Capillarity (moisture "wicking”) is addressed by foundation wall dampproofing and a sub-slab polyethylene vapor barrier. However, there is a gap in this barrier at the footing and moisture can wick at this point and accumulate behind impermeable insulation or finishes (Figure 8). It can also be a moisture source in open-core CMU walls. This problem is solved using a capillary break over footing in new construction; however, retrofit assemblies must address this issue by some other means.

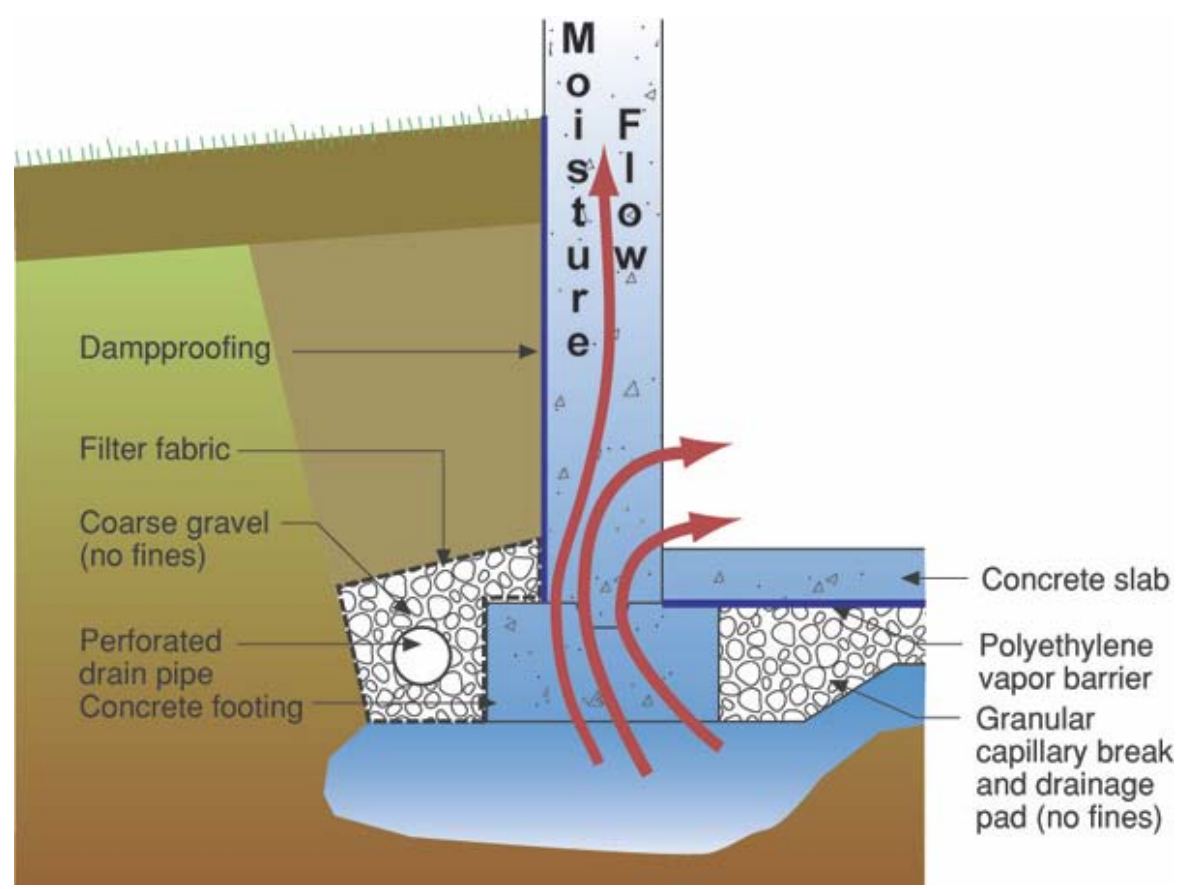

Figure 8. Capillary uptake of water through footing-to-foundation-wall connection 
Assemblies that solve all of the problems should (a) be constructed with a moisture-tolerant layer against the foundation wall, so that they can survive incidental wetting, (b) control air leakage/movement into and out of the assembly, and thus condensation, and (c) allow limited drying to the interior (optional). Examples of these assemblies are given in Lstiburek (2006).

The "hybrid" systems discussed in this report add a further function on top of these criteria: to deliberately handle leakage of bulk water through the foundation wall.

\subsection{Foundation Freezing Issues due to Insulation Retrofit}

One reported objection to insulation of foundations is the perceived risk of freezing-based damage to the foundation, caused by reduced heat loss to the ground, specifically, frost heaving of the foundation wall, or adfreezing (or adhesion freezing) damage. Frost heaving is the mechanism of soil expansion due to a combination of freezing conditions in the soil, moisture saturation of the soil, and frost-susceptible soils. Adfreezing is the phenomenon of frozen soil adhering to a foundation (friction and ice bonding), combined with frost heave lifting the foundation upwards. These topics are covered in detail by Lstiburek (2010b).

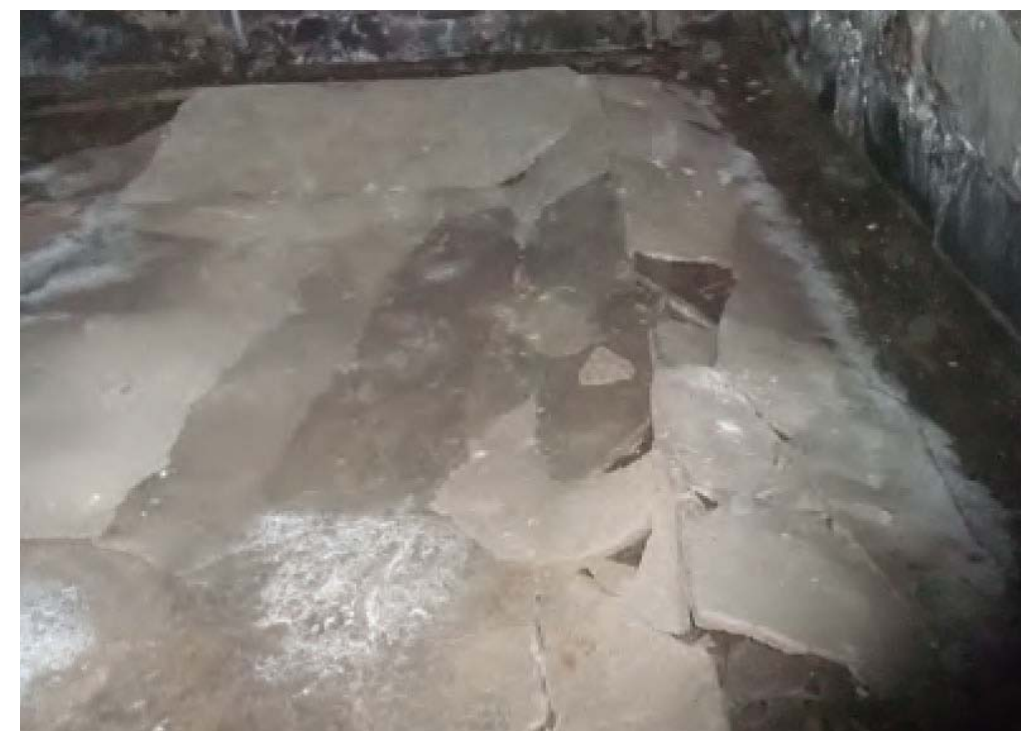

Figure 9. Basement slab heaving in unheated basement (Lstiburek 2010b)

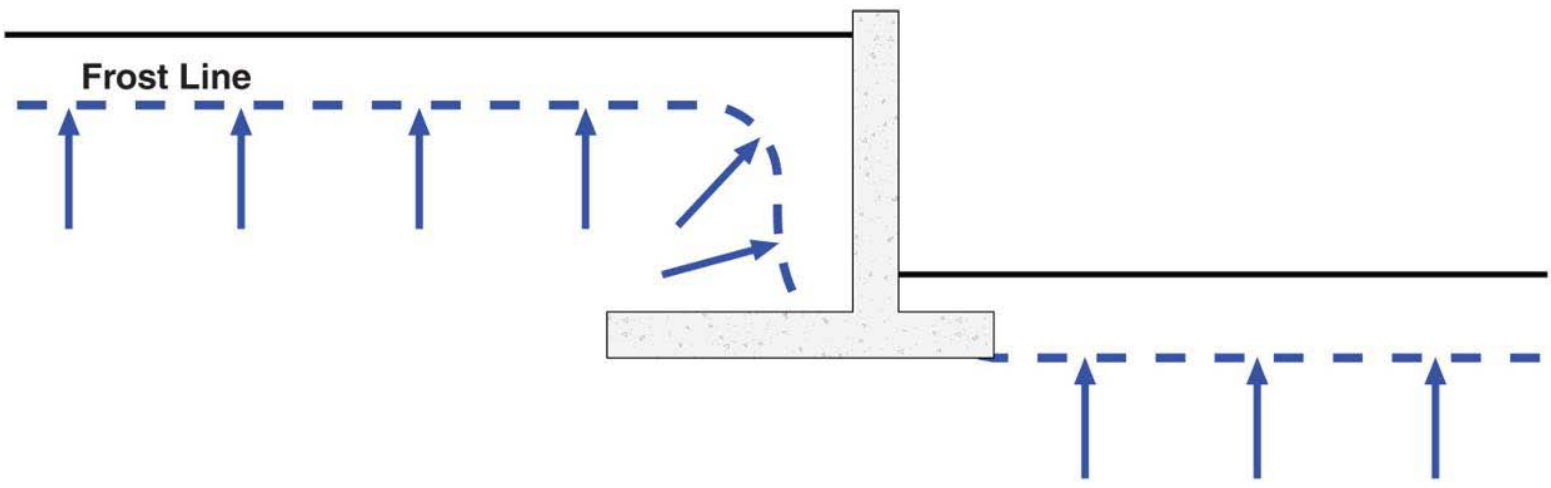

Figure 10. Frost Expansion. Freezing of frost-susceptible soil behind walls causing thrust perpendicular to the freezing front (Lstiburek 2010b) 
Work in Canada in the 1970s and 1980s (BETT 1985b) examined this issue by performing a country-wide survey to determine the incidence of foundation problems caused by foundation insulation retrofits. Teams were sent to investigate reports of these foundation failures; note that the areas of Canada included this survey are very cold climates (DOE Zones 6 and 7).

In general, the team found adfreezing problems in non-heated structures such as garages, and other general durability problems linked with poorly detailed interior insulation retrofits (condensation, mold, etc.). The frost heaving cases found were linked to exceptionally poor drainage and poor quality foundations, which would have affected either insulated or uninsulated foundations. Confirmed cases of living-space frost heave were never authenticated in this survey.

In order to have any of these freezing-based problems, frost penetration into the soil must be sufficiently deep to cause issues. In general, locations where the frost penetration depth is 60 inches or less (see Figure 11) are highly unlikely to experience any of these problems. For reference, this 60 " line is roughly coincident with the DOE Zone 5 to Zone 6 border.

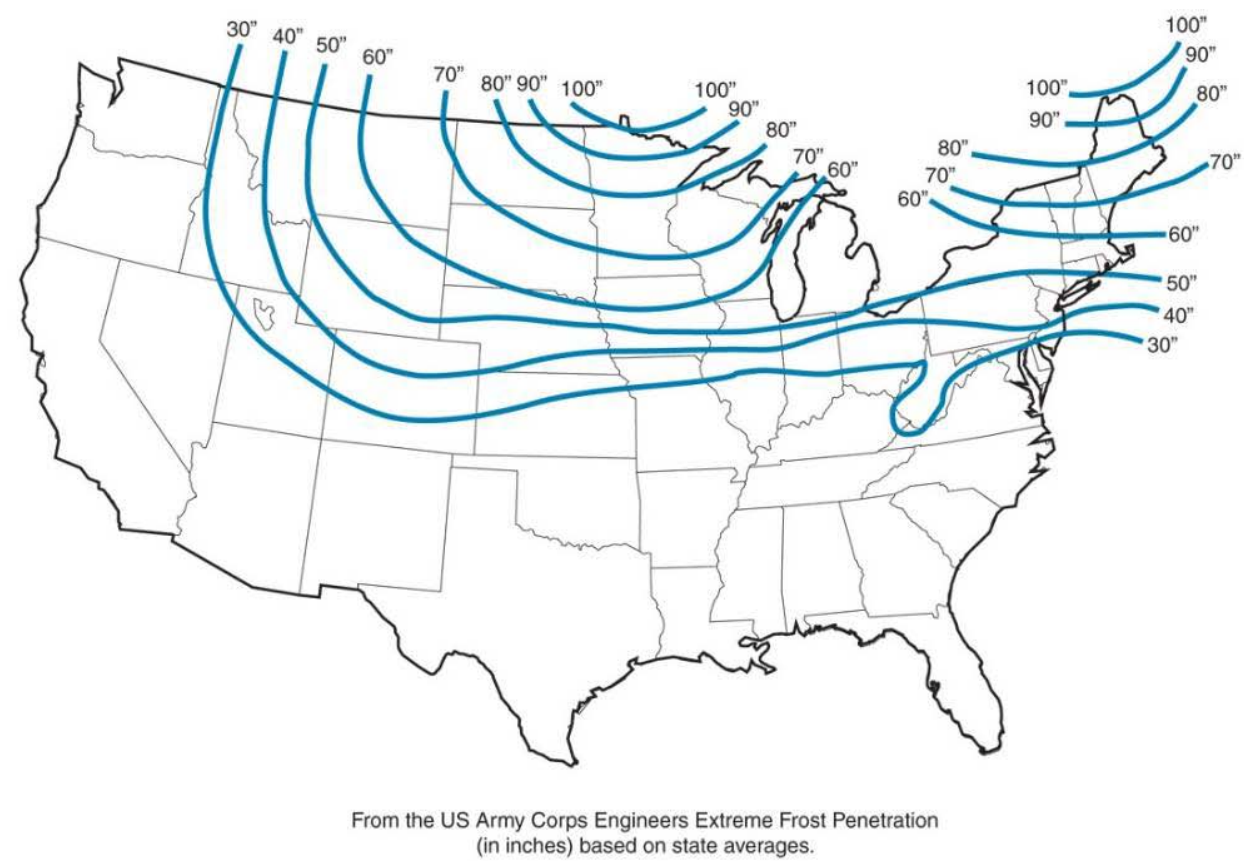

Figure 11. Extreme frost depth penetration map (Lstiburek 2010b)

The physics behind frost heave and adfreezing issues are based on soil moisture and freezing behavior. For these issues to occur, not only are freezing conditions required in the soil, but also the soil must be wet, and the soil needs to be a "frost susceptible" soil (over 3\% of grains finer than $0.02 \mathrm{~mm}$ in diameter by weight typical). The expansion experienced in frost heaving is not due to water volume expansion while freezing. It occurs because the freezing area draws water from surrounding soil, forming a "lens" or layer of ice (Penner 1962). The direction of the expansion or "heave" is a function of the direction of heat flow; the growth is in the direction of heat loss (i.e., from warm to cold). For instance, frost heaving of the ground occurs upwards, as the earth is warmer than the cold winter air. Therefore, frost heaving will not occur inwards into a heated basement, due to this directionality. This is even true for insulated basements - although the magnitude of heat flow is reduced, the direction remains the same. 
In addition, the phenomenon of adfreezing is another concern: the ground freezes and adheres to a foundation wall, and then frost heaving lifts the soil and the attached foundation. Again, the phenomenon is dependent on freezing direction: heat loss from the foundation to the soil results in no or minimal adhesion, while heat flow from the soil to the foundation results in formation of a frost-adhesion bond. Therefore, adfreezing can occur in unheated structures (e.g., unheated garages, pier foundations), but it will not occur in heated (and insulated) foundations due to the outward heat flow (Pressnail 1987).

The conceptual ground temperature profiles of heated and unheated basements (with adjacent snow cover) are compared in Figure 12 below. Frost penetration into the ground adjacent to the foundation is greater after insulation; however, the heat flow direction (and therefore risk of inward frost heaving) remains outward (although heat flows will shift).
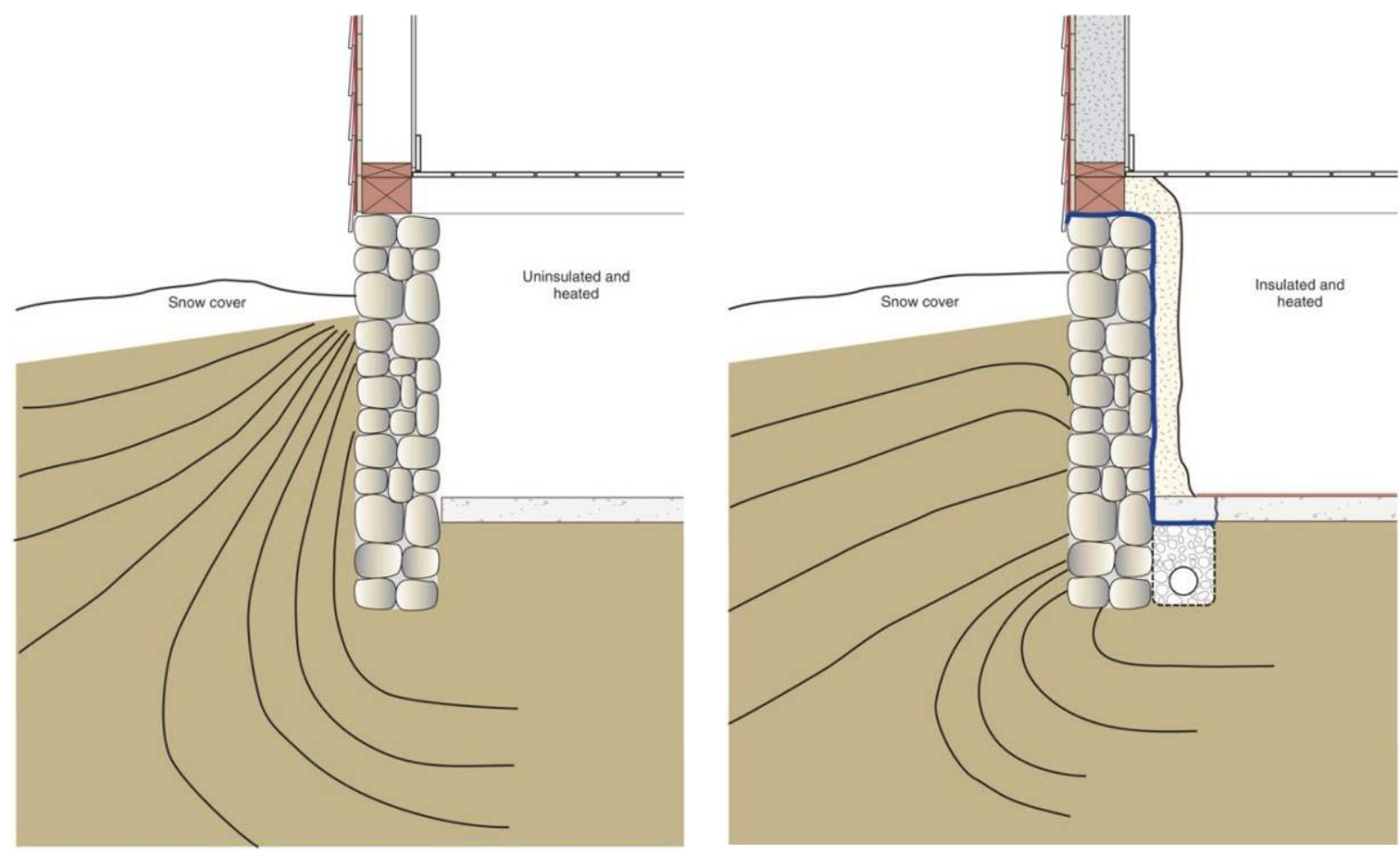

Figure 12. Uninsulated (L) and insulated (R) rubble basement comparison (Lstiburek 2010b)

If the intent is to leave the basement completely unheated, additional protection methods may be warranted. These would include the examples shown below. One is "wing" insulation (horizontal insulation extending out from the foundation wall, as per typical guidelines for shallow frostprotected foundations), which reduces the depth of frost penetration adjacent to the foundation (Figure 13, left). Alternately, frost heave issues can be controlled by eliminating frost-susceptible soils and/or improving exterior drainage (Figure 13, middle). Finally, many rubble foundations do not experience any frost issues (heated or unheated) because the foundation material itself provides a drainage path for the surrounding soil (Figure 13, right), thus preventing saturation of the adjacent soils. 

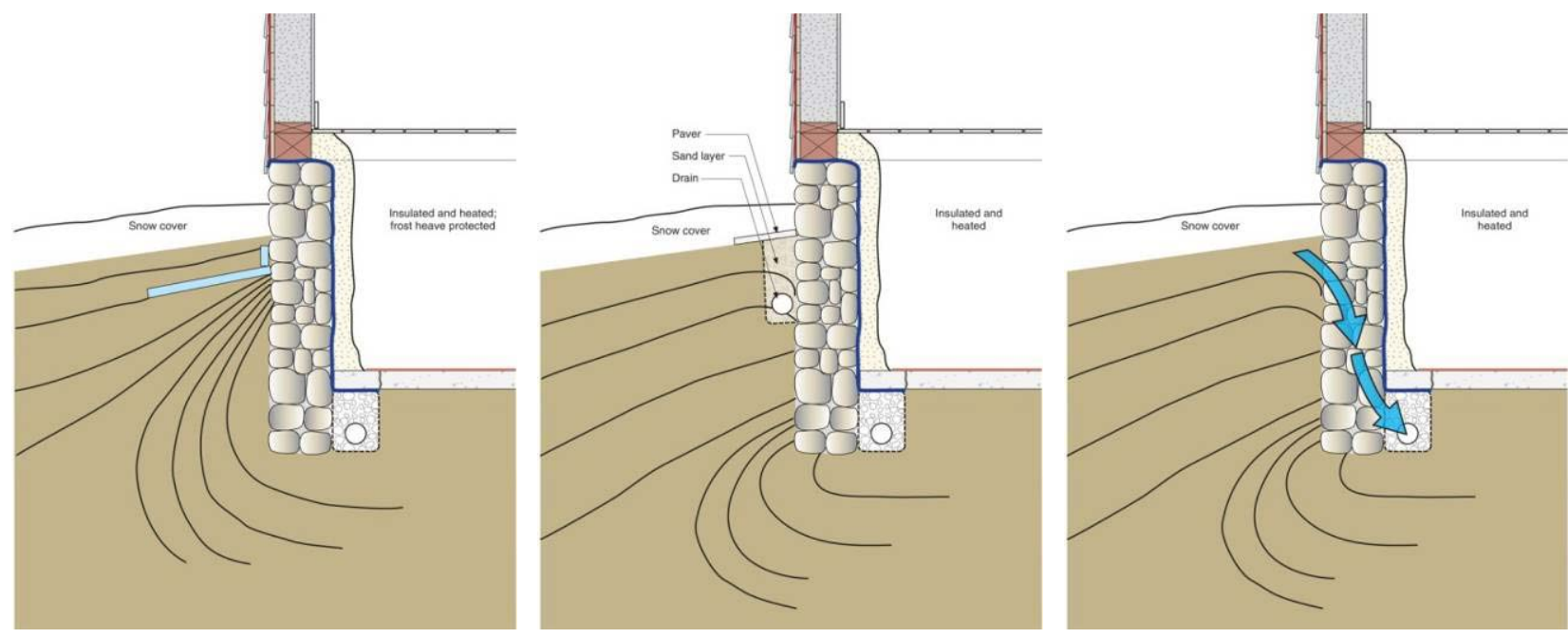

Figure 13. Exterior "wing" insulation (L), exterior water control measures (M), and drainage through the foundation wall (R) (Lstiburek 2010b)

A final issue to be considered is freeze-thaw damage to exposed masonry, such as brick or porous stone. Interior insulation will render this foundation wall colder (and wetter) than previous conditions, raising the risk of freeze-thaw damage. This issue is discussed in detail in the literature, and is being researched in the BSC report "Interior Insulation of Masonry Wall Assemblies" (Straube et al. 2011). However, as noted in Section 8 "Field Monitoring," there is evidence that the wall temperature is elevated by ground contact, thus providing a degree of "protection," from any freeze-thaw issues.

\subsection{Closed Cell Spray Foam Properties and Costs}

Most of the retrofit foundation wall assemblies discussed in this document use closed cell (2 pound/cubic foot) polyurethane spray foam as a solution to the moisture (bulk water, capillarity, vapor diffusion), air barrier, and insulation problems in "wet" assemblies. This material has an associated cost premium, but in these specific applications, it may be the only material that provides an effective solution.

\subsubsection{Material Properties}

To examine the suitability of ccSPF for this application, the material properties can be examined in detail, and then compared to its required function.

ASHRAE Handbook-Fundamentals (ASHRAE 2009) gives material properties for closed cell spray polyurethane foam. It gives an insulating value of R-6.06 per inch $(0.025 \mathrm{~W} / \mathrm{m} \cdot \mathrm{K})$ for "aged and dry" 2 PCF $\left(32 \mathrm{~kg} / \mathrm{m}^{3}\right.$ ) foam. Water vapor permeability (for $2.4 \mathrm{PCF}$ or $39 \mathrm{~kg} / \mathrm{m}^{3}$ foam) is given as 1.6 perm-inch (at $10 \% \mathrm{RH}$ ) to 2.2 perm-inch (at $90 \% \mathrm{RH}$ ), or 2.34 to 3.22 $\mathrm{ng} /(\mathrm{Pa} \cdot \mathrm{s} \cdot \mathrm{m})$.

Additional material properties are shown in Table 1 below for a specific manufacturer's foam (CertainTeed CertaSpray® Closed Cell Foam); however, most 2 PCF foams have similar material properties, so the values below can be considered a representative example. 
Table 1. Representative Material Properties of Closed Cell ( 2 pound/cubic foot) Spray Foam

\begin{tabular}{|c|c|c|c|}
\hline Property & ASTM Method & \multicolumn{2}{|c|}{ Value } \\
\hline Core Density, pcf & D1622 & \multicolumn{2}{|c|}{$1.9-2.4$} \\
\hline $\begin{array}{l}\text { Thermal Resistance (aged) } \\
\text { at } 75^{\circ} \mathrm{F},\left(\mathrm{h} \cdot \mathrm{ft}^{2} \cdot{ }^{\circ} \mathrm{F}\right) / \mathrm{Btu}\end{array}$ & C518 & \multicolumn{2}{|c|}{$5.8<2 "$} \\
\hline $\begin{array}{c}\text { Thermal Resistance (initial) at } \\
75^{\circ} \mathrm{F},\left(\mathrm{h} \cdot \mathrm{ft}^{2} \cdot{ }^{\circ} \mathrm{F}\right) / \mathrm{Btu}\end{array}$ & C518 & \multicolumn{2}{|c|}{6.7} \\
\hline Closed Cell Content, \% & D2842 & \multicolumn{2}{|c|}{$88-95 \%$} \\
\hline Compressive Strength, psi & D1621 & \multicolumn{2}{|c|}{$>25$} \\
\hline Tensile Strength, psi & D1623 & \multicolumn{2}{|c|}{60} \\
\hline $\begin{array}{l}\text { Water Absorption, } \\
\% \text { by volume }\end{array}$ & D2842 & \multicolumn{2}{|c|}{$<2 \%$} \\
\hline $\begin{array}{l}\text { Dimensional Stability, } 75^{\circ} \mathrm{F} / \\
95 \% \mathrm{RH}, 28 \text { Days, volume \% }\end{array}$ & D2126 & \multicolumn{2}{|c|}{$<9 \%$} \\
\hline $\begin{array}{c}\text { Water Vapor Transmission } \\
\text { (Permeability), perm-inch } \\
\text { (dry cup) }\end{array}$ & E96 & \multicolumn{2}{|c|}{1.51} \\
\hline Permeance (perms) (dry cup) & E96 & $\begin{array}{l}1.51 @ 1 " \\
0.76 @ 2^{\prime \prime} \\
0.50 @ 3^{\prime \prime}\end{array}$ & $\begin{array}{l}0.38 @ 4 " \\
0.30 @ 5 " \\
0.25 @ 6 "\end{array}$ \\
\hline $\begin{array}{l}\text { Air Permeability, at 1" } \\
\quad \text { thickness, } \mathrm{L} / \mathrm{s} \cdot \mathrm{m}^{2}\end{array}$ & E283 & \multicolumn{2}{|c|}{0.013} \\
\hline Fungi Resistance & $\mathrm{C} 1338$ & \multicolumn{2}{|c|}{ Pass, with no growth } \\
\hline
\end{tabular}

These values can be compared with the control functions that the assembly must accomplish, including the following:

Thermal control layer (insulation): The material functions as insulation (at roughly R-6 per inch); it exceeds typical requirements for basement and crawl space wall insulation (R-10/RSI 1.76) in a $2 \mathrm{inch} / 51 \mathrm{~mm}$ thickness.

Air control layer (air barrier): The material qualifies as an "air impermeable material." The requirement for an air barrier material is a maximum of $0.021 /\left(\mathrm{s} \cdot \mathrm{m}^{2}\right) @ 75 \mathrm{~Pa}$; ccSPF meets this requirement at $0.0131 /\left(\mathrm{s} \cdot \mathrm{m}^{2}\right) @ 75 \mathrm{~Pa}$. This material property also addresses the interstitial condensation issues discussed previously (preventing interior air from contacting the cool masonry surface). In addition, a continuous air barrier is required for soil gas (including radon) control.

Vapor control layer (vapor retarder): The material has a water vapor permeability of 0.8 perms at a 2 " thickness $\left(46 \mathrm{ng} /\left(\mathrm{Pa} \cdot \mathrm{s} \cdot \mathrm{m}^{2}\right)\right.$ in $\left.51 \mathrm{~mm}\right)$ at dry cup conditions, and lower permeability at greater thicknesses. It has sufficient vapor resistance to substantially reduce interior moisture loading from wet foundations, as discussed in Section 5 "Hygrothermal Simulations." This is even true in designs that do not include a vapor impermeable drainage layer (self-adhered membrane or air gap membrane). 
Water control layer (drainage plane/bulk water control): The material is intrinsically moisture tolerant (and hydrophobic), with a high closed cell content, low water absorption, and a low risk of fungal growth. Therefore, it is suitable for use for bulk water control, and use in a damp environment such as against a wet foundation wall.

Closed cell polyurethane spray foam also sticks tenaciously to many substrates, including wood, and masonry (such as rubble foundations). However, excess dust can prevent adhesion.

This discussion of material properties raises the question of the suitability of open cell spray foam (ocSPF; also known as 0.5 pound/cubic foot foam) in this application. It meets requirements for an air barrier material (typical values in the range of 0.001 to $0.009 \mathrm{~L} / \mathrm{s} \cdot \mathrm{m}^{2} @$ 3.5"). However, its open cell content and high water vapor permeability (11 perms @ 5.5" or 627 $\mathrm{ng} /\left(\mathrm{Pa} \cdot \mathrm{s} \cdot \mathrm{m}^{2}\right)$ in $\left.140 \mathrm{~mm}\right)$ make its material properties substantially different from closed cell foams. Although the specified water absorption is $1.7 \%$ by weight (similar to ccSPF), the open cell structure would appear to put the material at greater risk in continually wet/damp applications. One manufacturer's literature recommends against using ocSPF in foundations with bulk water problems.

The high vapor permeability of ocSPF could increase the risk of condensation at the insulationfoundation wall interface: this would be a function of interior humidity and surface temperature, which is in turn a function of climate. However, Goldberg and Farkas (2004) demonstrated that frost accumulation on the above-grade portion of the wall is possible with this material in a foundation application.

\subsubsection{Material and Installed Costs}

Installed cost of closed cell spray foam varies strongly based on contractor availability, the size of the installation, regional pricing, feedstock (crude oil) prices, and access (e.g. requirement for lifts or scaffolding; confined space installation). However, a typical installed price used for estimation purposes is roughly $\$ 1$ /board foot (1" x 12 " x 12"), although pricing variations range in practice anywhere from $\$ 0.45$ to $\$ 1.40 /$ board foot.

A comparison of insulation material costs is shown below in Figure 14, based on "big box" home center pricing gathered from 2007 through 2011. It is shown using the normalization metric of $\$ / s f \cdot R$ value, which normalizes the area costs based on the $R$ values. 


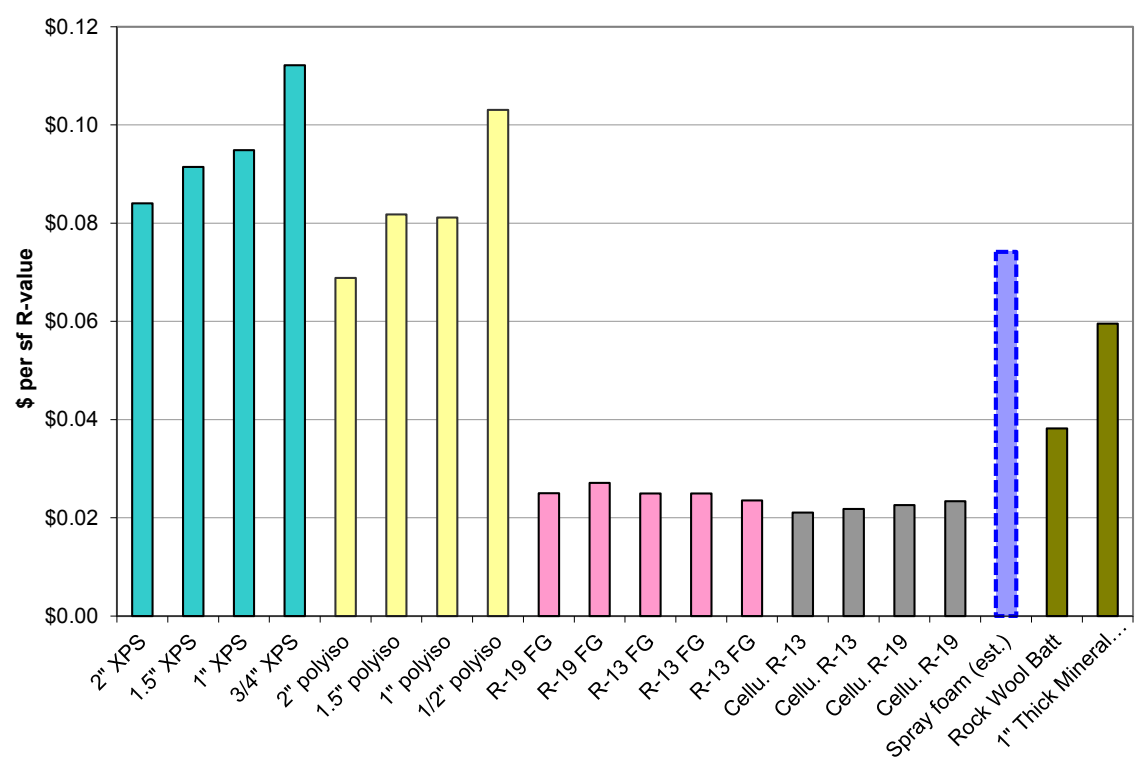

Figure 14. Insulation material costs (no installation), in $\$ / s f \cdot R$ value

It shows values for extruded polystyrene (XPS), polyisocyanurate, fiberglass, cellulose, spray foam, and mineral fiber. Note that closed cell spray foam is included in the graph with a caveat: there is no isolated "material cost" for ccSPF, since it is effectively manufactured and installed as a single step. An estimate was made using the $\$ 1 /$ board foot price and dividing by $2(1 / 2$ materials and $1 / 2$ labor).

It is evident from the graph that ccSPF is at a comparable price to the rigid board foam plastic products (XPS and polyisocyanurate), which are both substantially more expensive than cavity fill fibrous insulation, such as fiberglass or cellulose.

Closed cell SPF, XPS, and polyisocyanurate are all premium products - with an associated cost penalty - because they are air impermeable insulation materials that are intrinsically moisturetolerant. When designing enclosures, these premium materials should be used to take advantage of these properties. Assembly R value can be augmented (if desired) with lower cost fibrous insulation products, assuming that durability is not compromised by adding it to the design.

\subsubsection{Fire Protection Requirements}

When using interior spray foam, one factor that must be considered is its fire protection requirements. In the International Residential Code for One- and Two-Family Dwellings (ICC 2009), this material is covered in the Foam Plastics section (R316) with requirements as follows:

R316.4 Thermal barrier. Unless otherwise allowed in Section R316.5 or Section R316.6, foam plastic shall be separated from the interior of a building by an approved thermal barrier of minimum $1 / 2$ inch $(12.7 \mathrm{~mm})$ gypsum wallboard or an approved finish material equivalent to a thermal barrier material that will limit the average temperature rise of the unexposed surface to no more than $250^{\circ} \mathrm{F}$ $\left(139^{\circ} \mathrm{C}\right)$ after 15 minutes of fire exposure complying with the ASTM E 119 or UL 263 standard time temperature curve. The thermal barrier shall be installed in 
such a manner that it will remain in place for 15 minutes based on NFPA 286

with the acceptance criteria of Section R302.9.4. FM 4880. UL 1040 or UL 1715.

In the assemblies covered here, this has typically been addressed by installing framing and interior gypsum board. Note that if steel studs are used for wall framing, the studs must be kept clear of the insulation to avoid thermal bridging issues, which degrades the overall R-value of the assembly. Thermal bridging issues are not as severe with wood studs, but they must be held 1" off of the masonry wall (at a minimum) to ensure air barrier continuity, and to isolate the wood from elevated moisture conditions

An alternate solution is intumescent paint, which in presence of fire, chars and swells to form fire-protective coating. Installed costs for intumescent paints are in the range of $\$ 0.35$ to $\$ 0.65$ per square foot; which is relatively high (almost comparable to board foot cost of foam). However, it is more economical than a framed wall with gypsum board (estimated $\sim \$ 3-4 / \mathrm{sf}$ ). On the other hand, in some cases, it may be a logical decision to use gypsum board as the interior thermal barrier, which adds the benefit of a finished interior appearance.

IRC Section R316.5 deals with exceptions for roofs, attics, crawl spaces, and other cases. In attics and crawl spaces that are only accessed for maintenance purposes, the fire protection requirement drops from a "thermal barrier" to an "ignition barrier," which has less stringent requirements. The intent of the ignition barrier is to keep a flame source from directly contacting the foam surface.

R3l6.5.4 Crawl spaces. The thermal barrier specified in Section R316.4 is not required where all of the following apply:

1. Crawlspace access is required by Section R408.4

2. Entry is made only for purposes of repairs or maintenance.

3. The foam plastic insulation is protected against ignition using one of the following ignition barrier materials:

3.1. 1-1/2-inch-thick $(38 \mathrm{~mm})$ mineral fiber insulation;

3.2. 1/4-inch-thick $(6.4 \mathrm{~mm})$ wood structural panels;

3.3. 3/8-inch $(9.5 \mathrm{~mm})$ particleboard;

3.4. 1/4-inch (6.4 mm) hardboard;

3.5. 3/8-inch (9.5 mm) gypsum board; or

3.6. Corrosion-resistant steel having a base metal thickness of $0.016 \mathrm{inch}$ $(0.406 \mathrm{~mm})$.

The above ignition barrier is not required where the foam plastic insulation has been tested in accordance with Section R316.6

For reference, Section R316.6 deals with specific approvals not covered above. In addition to the above list, intumescent paint can also be used as an ignition barrier: less thickness than the morestringent thermal barrier application is required. 
EDU (2009) reported that another test (SwRI 99-02) has gained acceptance as an alternate means of complying with the "ignition barrier" requirement for crawl spaces and attics. It is also referred to as a "modified NFPA 286 test." Several manufacturers have foams that meet the requirements of this test without an intumescent coating, which improves their cost-effectiveness in crawl space applications. However, it is important to realize that this code provision only applies to limited-access crawl spaces: in full basements; the foam cannot be left exposed without interior gypsum board or intumescent paint.

\subsection{Critical Takeaways}

The recommended approach for high performance homes is to include a basement within the conditioned space (i.e., insulating at the foundation walls). Isolating the basement (i.e. insulating at the basement ceiling) typically results in poor performance, including high overall air leakage, which is not acceptable for high performance housing. If an effective air barrier can be created at the first floor plane, it may be an acceptable option, but evidence suggests that this is unlikely.

Moisture damage risks when insulating below-grade walls include bulk water, flooding, ground moisture, wintertime and summertime interstitial condensation, soil gas, construction moisture, and capillary rise at footings. Assemblies that solve all of the problems need to (a) be constructed with a moisture-tolerant layer against the foundation wall, so that they can survive incidental wetting, and (b) control air leakage/movement into and out of the assembly, and thus condensation.

One reported objection to insulation of foundations is the perceived risk of freezing-based damage to the foundation, caused by reduced heat loss to the ground: specifically, frost heaving of the foundation wall, or adfreezing damage. In DOE Zone 5 and warmer climates, these issues are unlikely. In colder climates (DOE Zone 6 and higher), caution may be warranted, but the research literature indicates that soil freezing behavior results in less chance of damage in heated (even insulated) basements. Remedial measures such as "wing" insulation and additional drainage may be warranted in areas with frost-susceptible soils.

Closed cell polyurethane spray foam has material properties that let it function as a thermal control layer (insulation), air control layer (air barrier/air impermeable material), vapor control layer (vapor retarder), and water control layer (drainage plane/bulk water control).

ccSPF has a cost premium associated with it, but in these specific applications, it may be the only material that provides an effective solution.

In a basement application, the spray foam must be protected from the interior by $1 / 2$ " gypsum board or intumescent paint ("thermal barrier").

In a limited-access crawl space application, the spray foam must be protected from the interior by a less restrictive "ignition barrier" (see list above). Alternately, some manufactures have met the ignition barrier requirement with bare foam (see manufacturers' specifications). 


\section{Previous Work}

There is some existing work both in the technical literature and the trade press that is useful to cover in order to put the assemblies discussed in the following sections in context.

\subsection{Goldberg and Farkas (2004)}

Goldberg and Farkas (2004) compared a variety of vapor control strategies using open cell spray polyurethane foam ( 0.5 PCF) in wood and steel stud framed walls inboard of a concrete block foundation. The research was done at the Foundation Test Facility in Rosemount, Minnesota (just south of Minneapolis/St. Paul, in DOE Zone 6). Inspection ports were cut in the foam insulation to allow observations of interstitial conditions and weighing of the sample (to measure moisture uptake). Vapor control options included:

- Polyethylene on interior side of insulated cavity

- Polyethylene on exterior side of insulated cavity (between insulation and block wall)

- Polyethylene on both interior and exterior of insulated cavity

- No polyethylene on either side of insulation ("no polyethylene").

At mid-height (below grade portion of the wall), all walls showed minimal moisture uptake. At the above-grade portions of the wall, the assembly with polyethylene on the interior side of the insulated cavity showed a sharp rise in moisture content, indicating inward vapor drives and accumulation. This demonstrates that impermeable interior finishes/layers should not be used in foundation walls, unless the moisture is handled by some other means.

Testing was continued through a second winter; wintertime disassembly of the "no polyethylene" wall showed some frost accumulation occurring within the outer layer of the foam. This research is an interesting case study because the material eliminates airflow as a transport mechanism, and only shows diffusion. These results show that diffusion can transport sufficient moisture to cause frost accumulation within the insulation when run at a condition such as $68^{\circ} \mathrm{F} / 20^{\circ} \mathrm{C} / 40 \% \mathrm{RH}$ or $64^{\circ} \mathrm{F} / 18^{\circ} \mathrm{C} / 50 \% \mathrm{RH}\left(43-45^{\circ} \mathrm{F} /+6\right.$ to $7^{\circ} \mathrm{C}$ dewpoint). It was not determined conclusively if this would safely be stored and re-evaporated over the spring. As a reference point, the $3.5^{\prime \prime}(89 \mathrm{~mm})$ of ocSPF used here has a permeability of 24 perms.

Bulk water intrusion into the assembly was not tested in experiment. However, the manufacturer's literature shows applications applying ocSPF directly against the foundation wall, but with a caveat against installation in walls with bulk water penetration:

For retrofit applications: prior to installation... the foundation wall should be inspected for any indication of water penetration. If there is evidence the wall leaked water, then adequate construction measures should be taken to prevent any further water intrusion. 


\subsection{Trade Literature}

Several pieces of trade literature have some relevance, showing current state of knowledge and acceptance of various interior foundation retrofit techniques in the industry. It is acknowledged that the "industry" per se is not monolithic by any means, but it provides some indication of practices that are either common or gaining acceptance.

Janesky (2001) is the manufacturer and distributor of a proprietary system of interior basement water control products. His work addresses both exterior water control measures (dampproofing, perimeter drainage, roof gutters and downspouts), and interior methods. Interior methods include interior perimeter drains (at the slab edge) to intercept water weeping through the foundation walls. This method is a useful retrofit solution; however, the system leaves the sub-slab gravel/granular fill field open to the basement air at the perimeter; this has negative impacts if radon or other soil gases are a concern.

Anderson (2005) is a contractor specializing in basement waterproofing in New England (Vermont). His proposed solution is to retrofit interior perimeter drains; bulk water leakage from the walls is to be collected with the perimeter system described by Janesky (2001). As mentioned above, this drainage allows communication between interior air and sub-slab granular fill. The interior wall finish used with this system is a semi-rigid white plastic panel system that allows drainage behind it. The material is also vapor impermeable, and is intended to stop water vapor migration from the wall.

Lauten (2009) describes the renovation of a 200-year old mass masonry building in Northern Virginia. The basement suffered from seasonal flooding and an earth/mud floor; the proposed use of the renovated basement was conditioned space and mechanical equipment. Therefore, extensive water management was required, which included exterior drainage and grading, an interior perimeter drain, and a concrete slab with polyethylene vapor barrier and granular drainage beneath. A gap was provided at the edge of the slab to accept water leakage through the stone walls. The stone walls were only repointed and left exposed; no insulation was installed. Again, the provision for drainage connects the sub-slab gravel to the basement air, resulting in IAQ risks.

Overall, this literature indicates that interior perimeter drainage is an established and known solution for bulk water issues in basements.

\subsection{Building Envelope Services, Inc. (2008) AVID System}

Building Envelope Services, Inc. is a spray foam contractor and building enclosure consultant operating in the New England area (based in Vermont). They developed a system to address rubble masonry wall foundations with bulk water issues and poor/unknown drainage characteristics. It is meant to provide insulation (at the top of the wall), continuous air and vapor barriers, and a drainage path for seasonal water leakage that is isolated from interior space (unlike the examples described previously). The name coined for this assembly is the "AVID system" ("Air/Vapor/Insulation/Drainage"). Details of this wall system are shown in Figure 15; the contractor estimates that there are approximately 1,000 completed basements and crawl space projects in all Northeast states, dating back to 1993 . There are no reported complaints related to the system design. 
Measurements of various operating buildings showed that moisture and temperature conditions of basements and crawl spaces treated with AVID are similar to interior conditions.
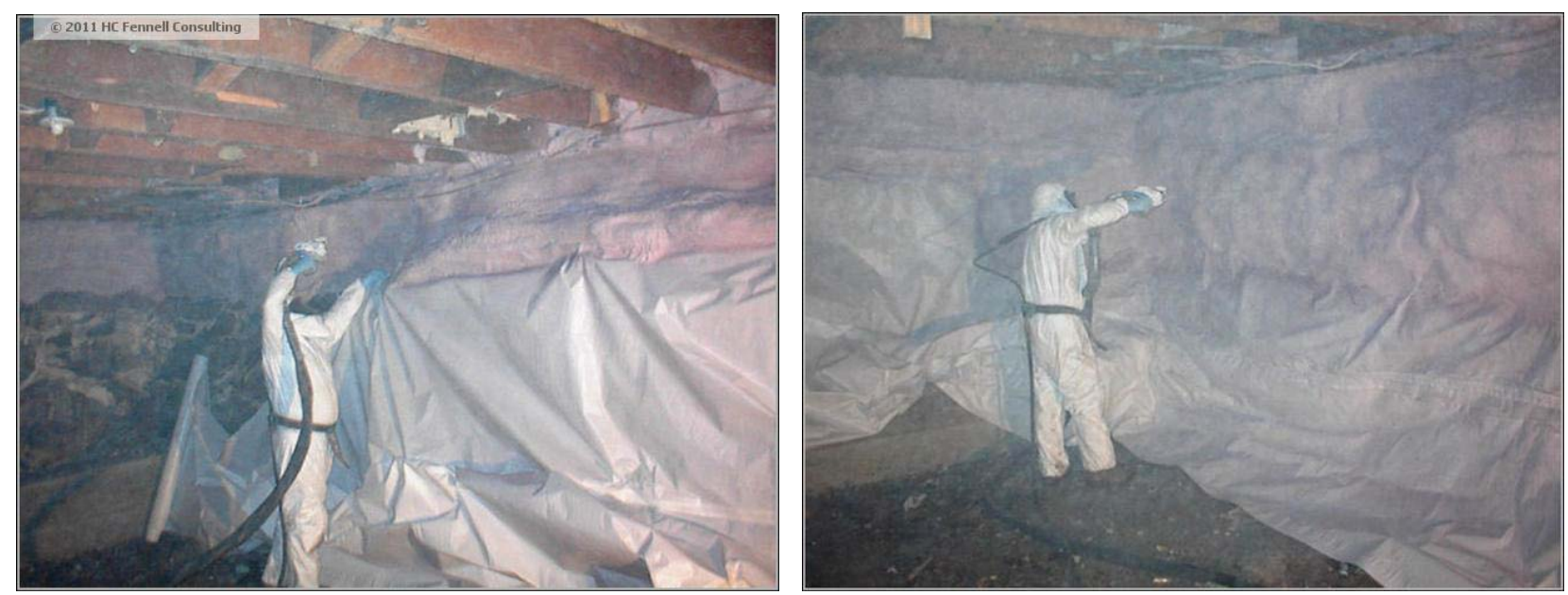

Figure 15. AVID installation (๑ 2011 by Henri Fennell; reprinted with permission)

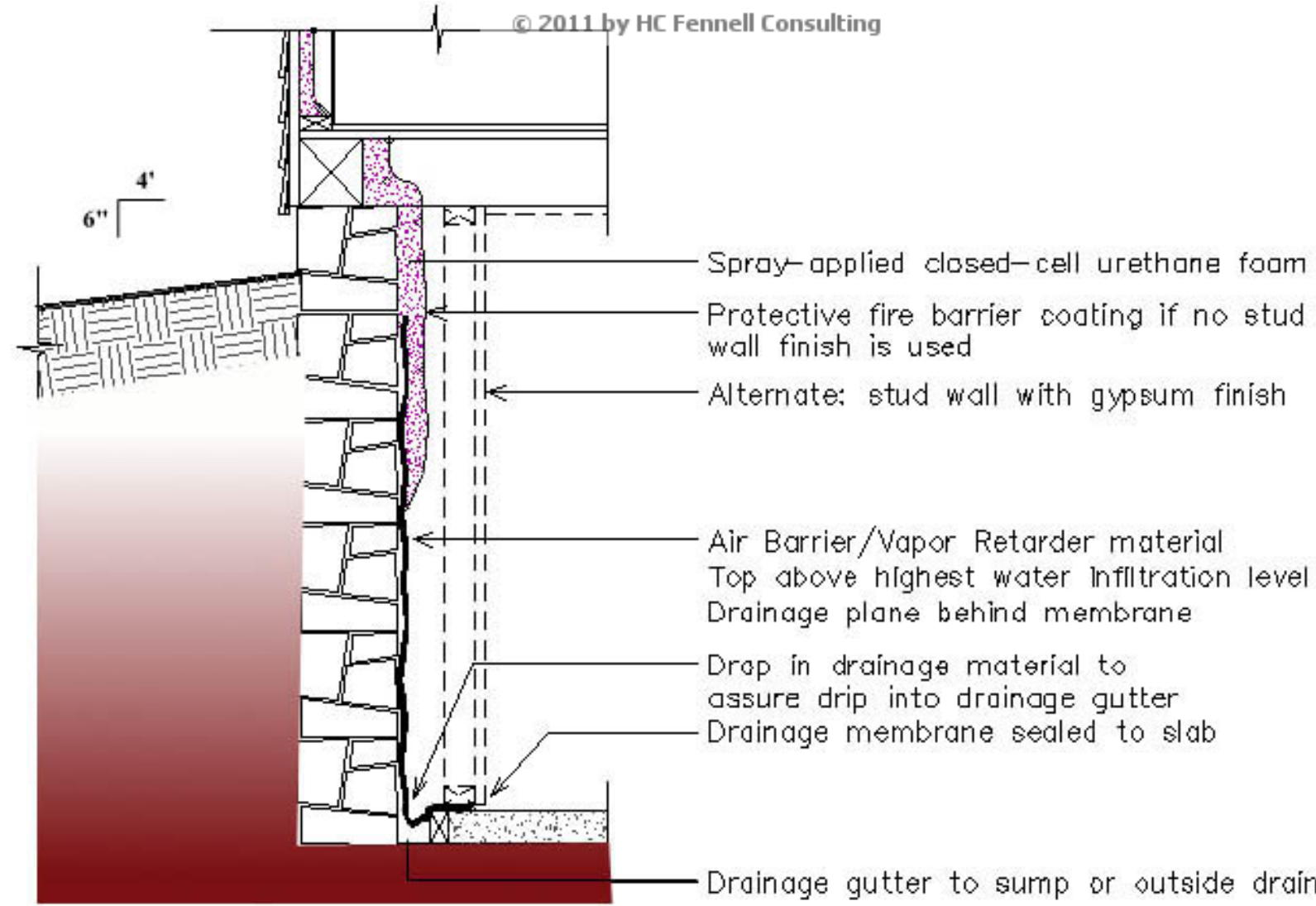

Figure 16. AVID diagram (๑ 2011 by Henri Fennell; reprinted with permission)

The installation of the system is as follows:

ccSPF is sprayed against from the underside of the first floor deck, onto the interior of the sill beam, down the foundation wall. The spray foam is terminated roughly 1 or 2 feet below grade; 
this is done to insulate at the maximum heat loss locations, but still allow heat flow for freezethaw resistance. This might not be necessary, but is a conservative decision by the contractor.

Air barrier, vapor retarder, and drainage plane continuity is obtained by lapping in a sheet membrane (reinforced polyethylene) on the lower part of the foundation wall. The upper edge of this drainage layer is set by the highest water infiltration level of the wall. This polyethylene allows drainage of seasonal water infiltration through the foundation wall

The polyethylene drainage layer is then draped into a perimeter gutter/trench, directing water infiltration to a drain or sump. The drainage layer is sealed to the edge of the slab to maintain air barrier continuity, thus eliminating any issues with soil gas infiltration into the house.

Overall, this system is substantially similar to hybrid foundation assemblies discussed in this report, except for the use of half-height insulation. But for reference, the developer of this system has also completed full height installations.

The uninsulated lower portion of the wall has some risk of surface condensation during spring periods (due to soil thermal mass); however, control of interior humidity levels can reduce likelihood of these problems.

\subsection{Critical Takeaways}

Open cell spray foam can function as foundation insulation directly against the foundation wall without vapor control if interior humidity levels are kept sufficiently low. However, higher humidity levels (40\%) pose some risks, at least in cold climates (DOE Zone 7 ).

Open cell spray foam is not recommended for use against wet foundations (i.e., bulk water leakage).

The use of retrofit interior perimeter drainage is well established in industry. However, common commercially available solutions connect the sub-slab granular drainage/gravel field to interior air. If there are radon or soil gas issues at the site, this solution may be unacceptable, particularly in energy retrofits with good airtightness.

The AVID system provides drainage of seasonal foundation leakage, air barrier and vapor control continuity, and insulation on the upper half of the basement wall. It also addresses the soil gas issues discussed above. 


\section{Recommended Designs and Variations}

This section covers several variants for addressing interior foundation retrofit insulation, with vapor control, air flow control, and incidental bulk water drainage. Note that in all of these designs, the basement will become more airtight. Therefore, combustion safety measures must be addressed for any fuel-burning appliance located in the basement/crawl space. This can include switching to sealed combustion appliances, or addition of combustion air measures. Another effect of increased airtightness is that radon can have greater accumulation rates. In locations with high radon levels, testing is recommended.

\subsection{Basic Design (Drained Assembly)}

The basic design of the "hybrid" foundation insulation system is shown in Figure 17; it is applicable to a variety of foundation materials, including brick, rubble stone, CMU block, and cast concrete.

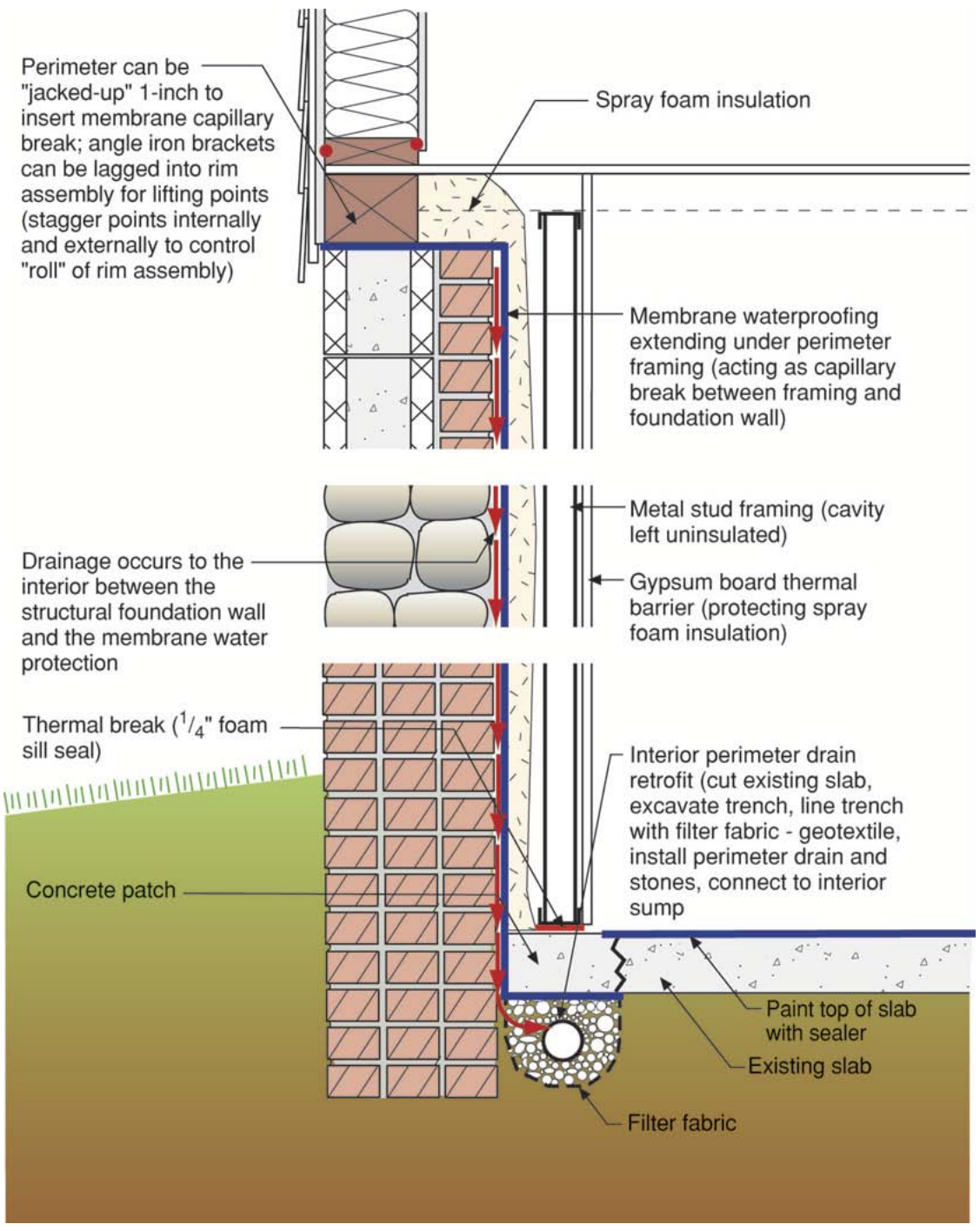

Figure 17. Interior drainage-renovation, showing various foundation wall materials 
The steps of implementation are shown below. The test case is the Westford House/Barn (see Section 7 "Field Survey Work", and Lstiburek 2010a). Both buildings were on rubble stone basements with severe seasonal bulk water infiltration problems and generally high moisture levels.
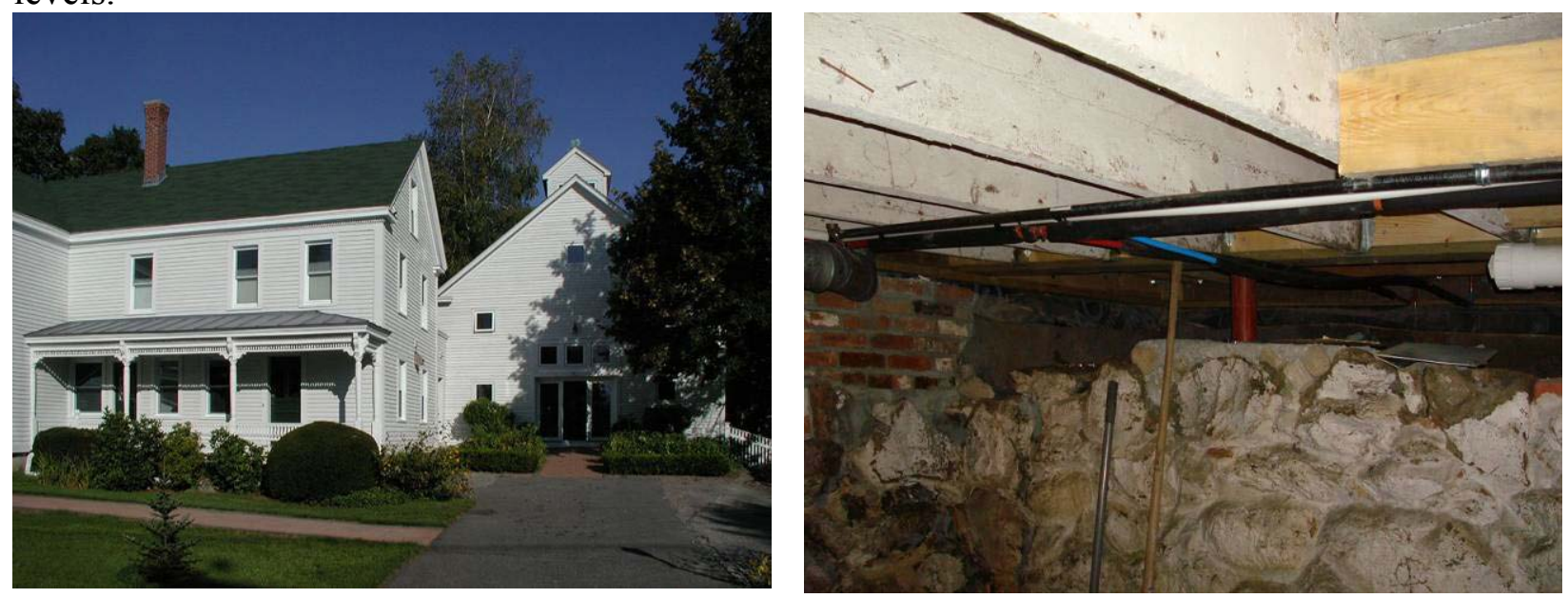

Figure 18. Overview of Westford House/Barn, existing foundation conditions (Lstiburek 2010a)

The exterior sill was raised slightly, in order to slip a self-adhered membrane capillary break underneath the sill. This can be achieved with angle irons and hydraulic jacks (interior and exterior), working in segments around the perimeter of the building, as shown in Figure 19. Cracking of interior plaster did not occur.

Granular fill and interior perimeter drainage were installed on top of the existing earth/slab floor, an XPS "bathtub" of insulation was placed, and a new concrete slab was cast. Perimeter drainage was connected to an interior sump. Note that Figure 17 shows a case of an uninsulated slab, with excavation and demolition only at the perimeter, to receive the interior perimeter drain. In the case of an uninsulated slab with no capillary control, some type of coating is required to control water vapor transmission from the slab surface.
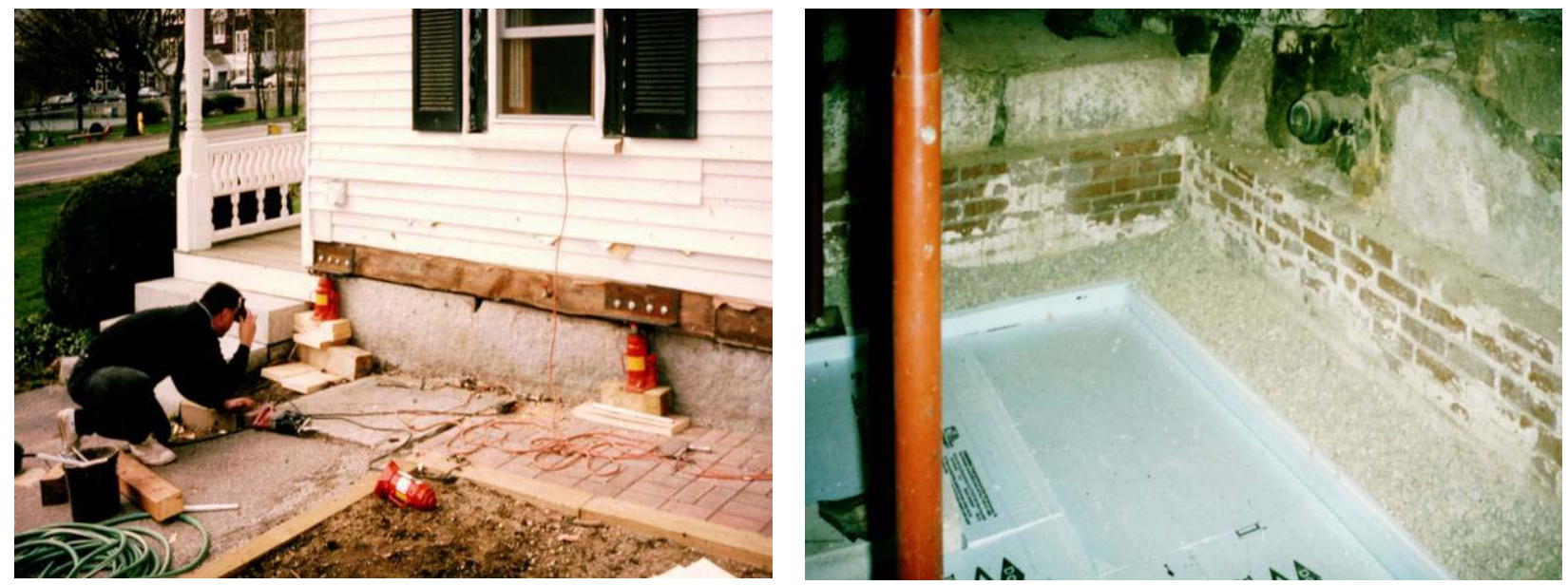

Figure 19. Sill beam lift and slab insulation and drainage (Lstiburek 2010a)

Self-adhered membrane was used as a drainage layer, which directs bulk water leakage penetrating through the foundation wall into the perimeter drainage system. The uneven surface 
of the rubble stone wall and the rigidity of the self-adhered membrane resulted in large gaps for drainage behind the membrane (see Figure 53). This drainage membrane is connected to the capillary break membrane under the sill. Closed cell spray foam was applied to the interior of the membrane, lapping onto the slab to provide air barrier continuity. The spray foam was left exposed.
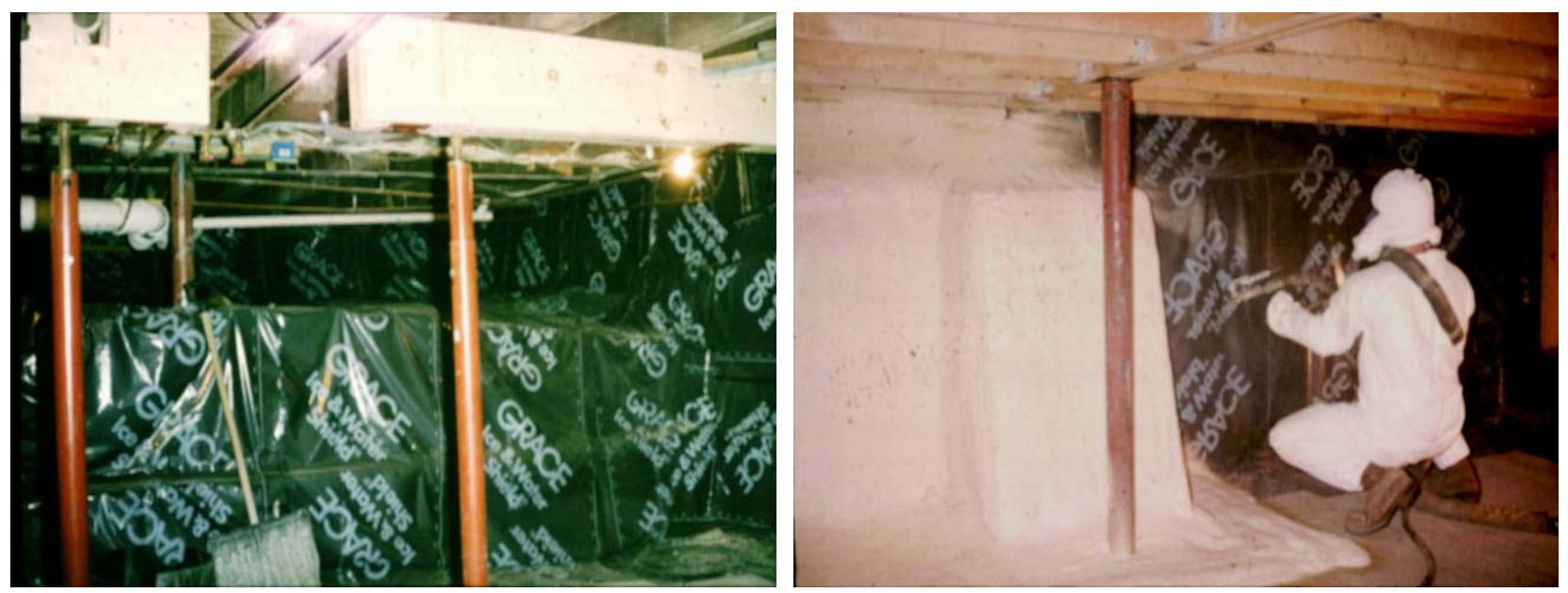

Figure 20. Self-adhered membrane and spray foam installation (Lstiburek 2010a)

\subsection{Air Gap Membrane Variant}

One variant is a more recent installation, which used an air gap membrane (a.k.a. 'dimple mat') in place of the self-adhered membrane as a water control layer. It was used in a basement/crawl space that has historically suffered from bulk water control problems. The foundation walls are granite rubble construction.

The air gap membrane was mechanically fastened to the wall, extending from slightly above grade level to the existing earth floor of the crawl space. Perimeter drainage was installed, and perimeter slab insulation (2"/51 mm XPS, 4"/1.2 $\mathrm{m}$ from the edge) was laid on top of the assembly. Note that the slab is only partially insulated. Closed cell spray foam was then sprayed against the air gap membrane, extending from the bottom of the first floor deck to the XPS perimeter insulation.
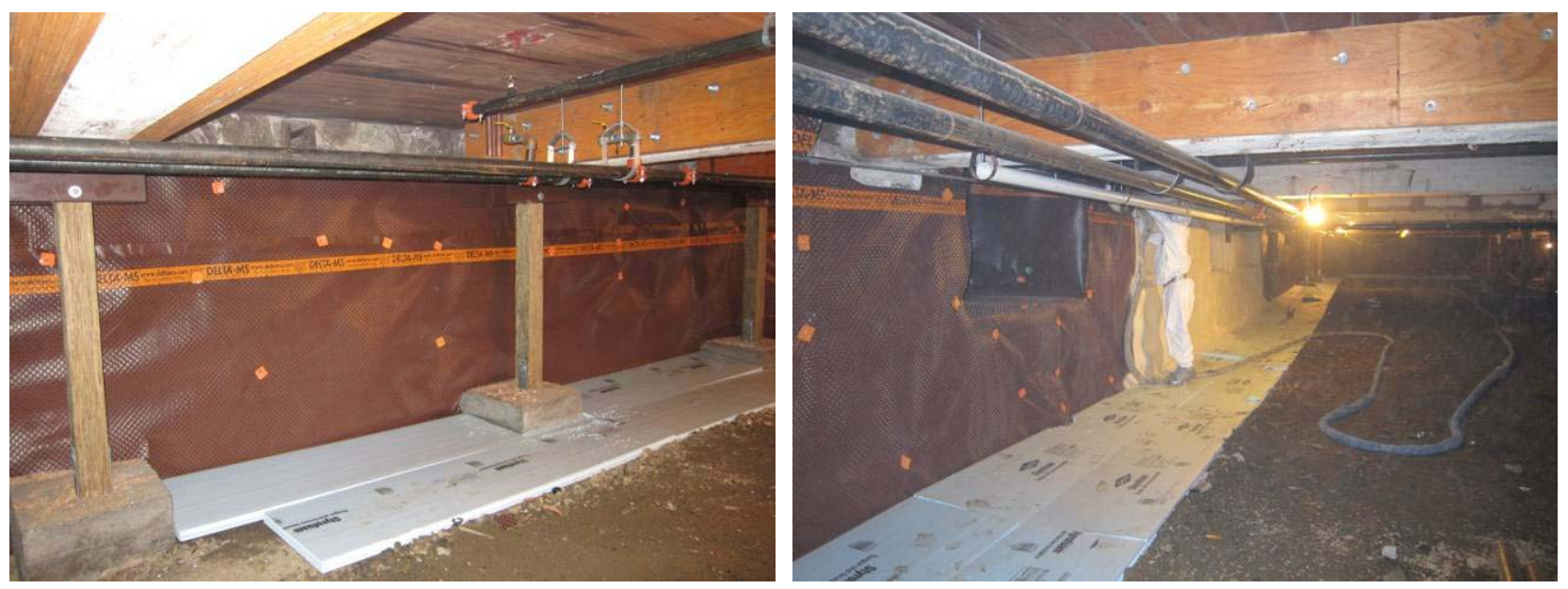

Figure 21. Air gap membrane under spray foam installation; 4' basement slab edge insulation 
A polyethylene ground cover was installed over the exposed earth and lapped onto the XPS insulation, and a $2 " / 51 \mathrm{~mm}$ "rat slab" was cast on top, to provide vapor control, air barrier continuity, and a durable walking surface for maintenance access.
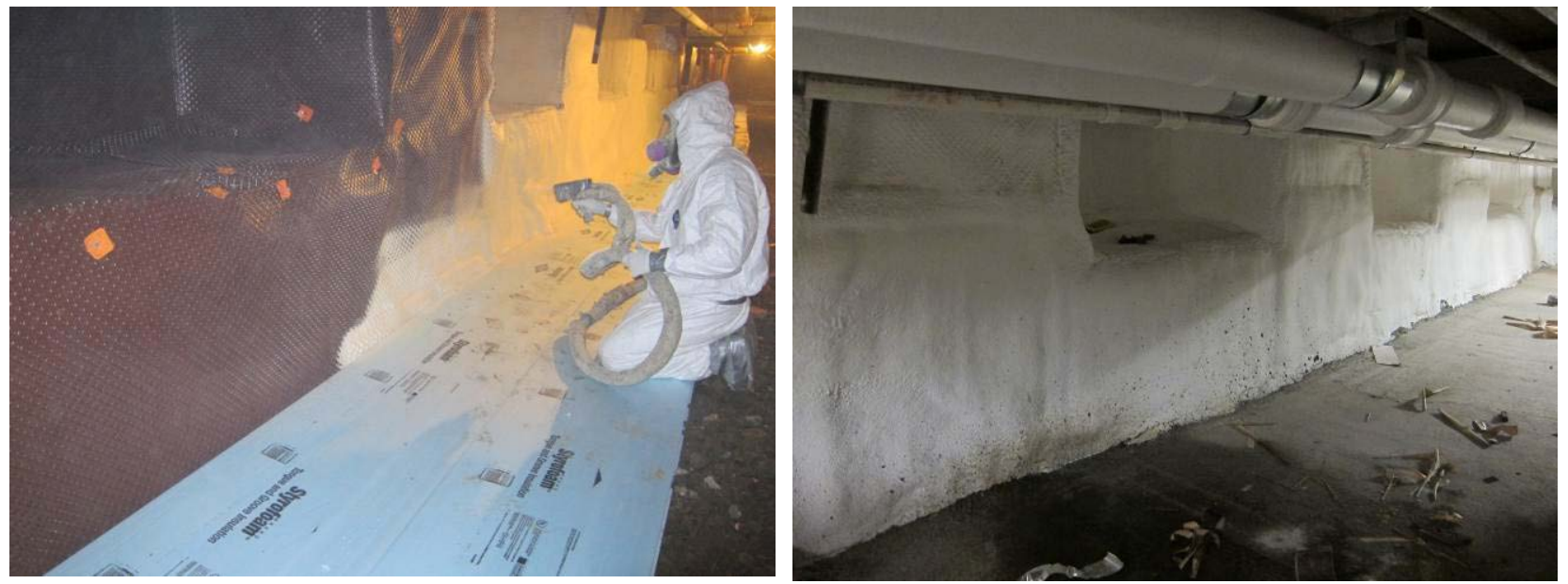

Figure 22. Spray foam slab edge insulation detail; completed installation of spray foam

Note that since the slab is being cast after installation of the ccSPF, the spray foam is acting as the basement slab edge thermal break.

One particular detail was the termination of the air gap membrane at embedded wood beams, as shown in Figure 23. This as-installed detail was a risky installation, because high relative humidity air (which will collect behind the air gap membrane) will be connected to moisturesensitive materials such as the wood beam. Instead, the air gap membrane was cut with a "pocket" around the beam, thus resulting in no air connection. Note that this air gap membrane must be sealed from the interior, to avoid venting of soil gases and high humidity air into the interior (now conditioned) space.
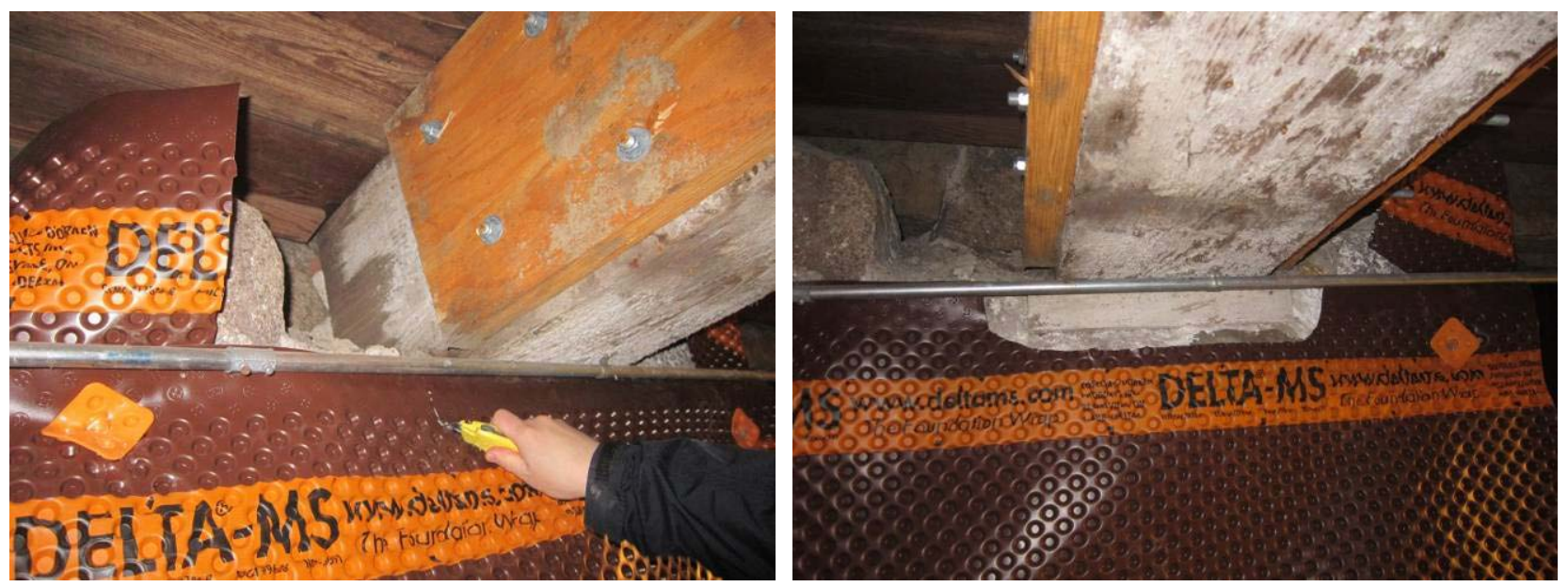

Figure 23. Air gap membrane venting to underside of beam (L); retrofitted detail (R)

The material cost for an air gap membrane is roughly $\$ 0.50$ per sf, which is comparable to selfadhered membranes. One advantage of this material is that it guarantees drainage air space gap. 


\subsection{Supplementary Fibrous Fill Insulation}

Given the high material cost of closed cell spray foam, in cases where high $\mathrm{R}$ values are targeted for foundation walls, use of lower-cost fibrous fill insulation may be more economical. An example is shown in Figure 24 below: an air gap membrane is applied to the foundation and 2$1 / 2$ " of spray foam is applied to the surface. An interior wood stud wall is then framed, and insulated with fibrous insulation, such as netted cellulose (shown), fiberglass, or mineral fiber. Images of the basement after spray foam and after cellulose insulation are shown in Figure 25 below.

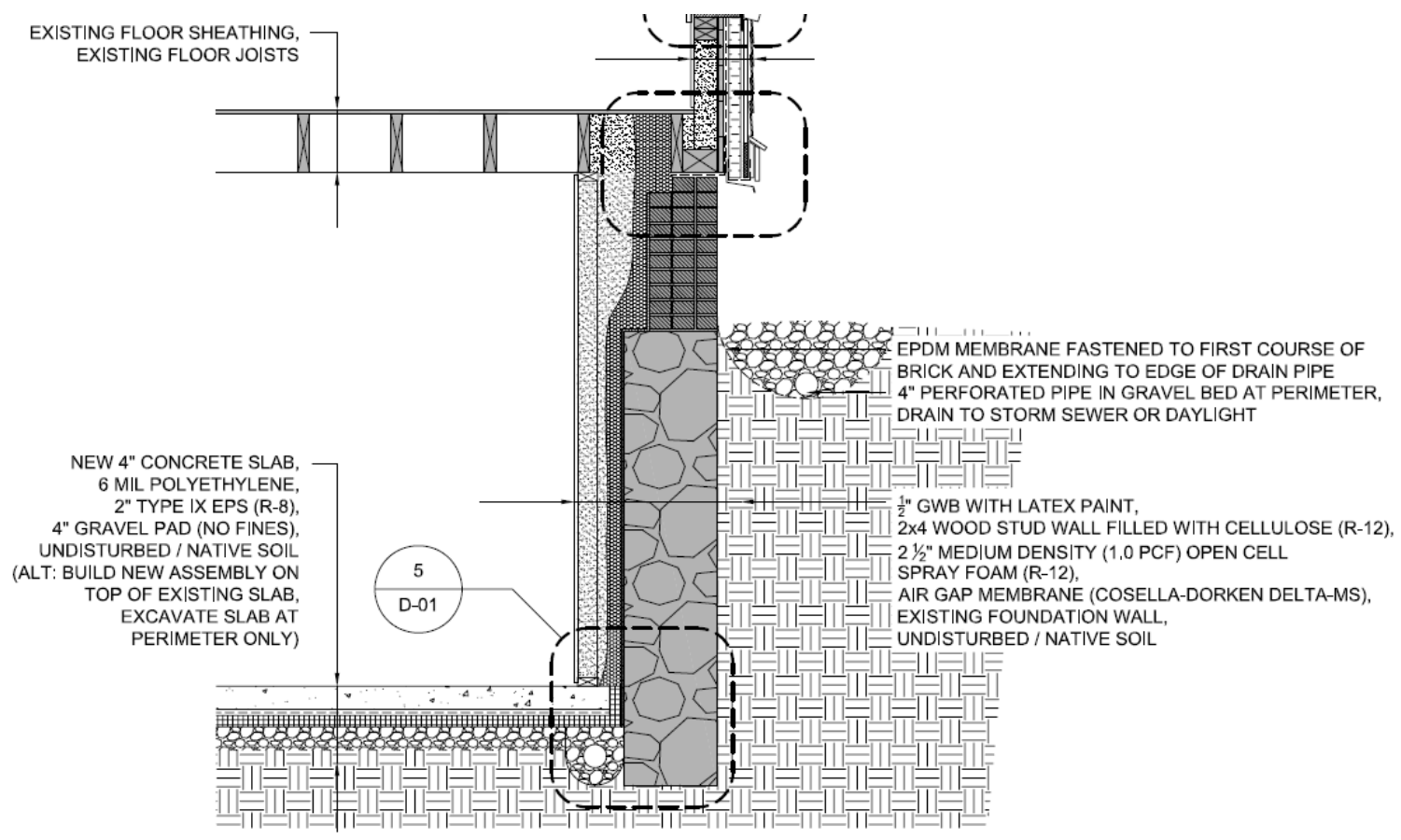

Figure 24. Spray foam and fibrous fill (netted cellulose) foundation insulation assembly
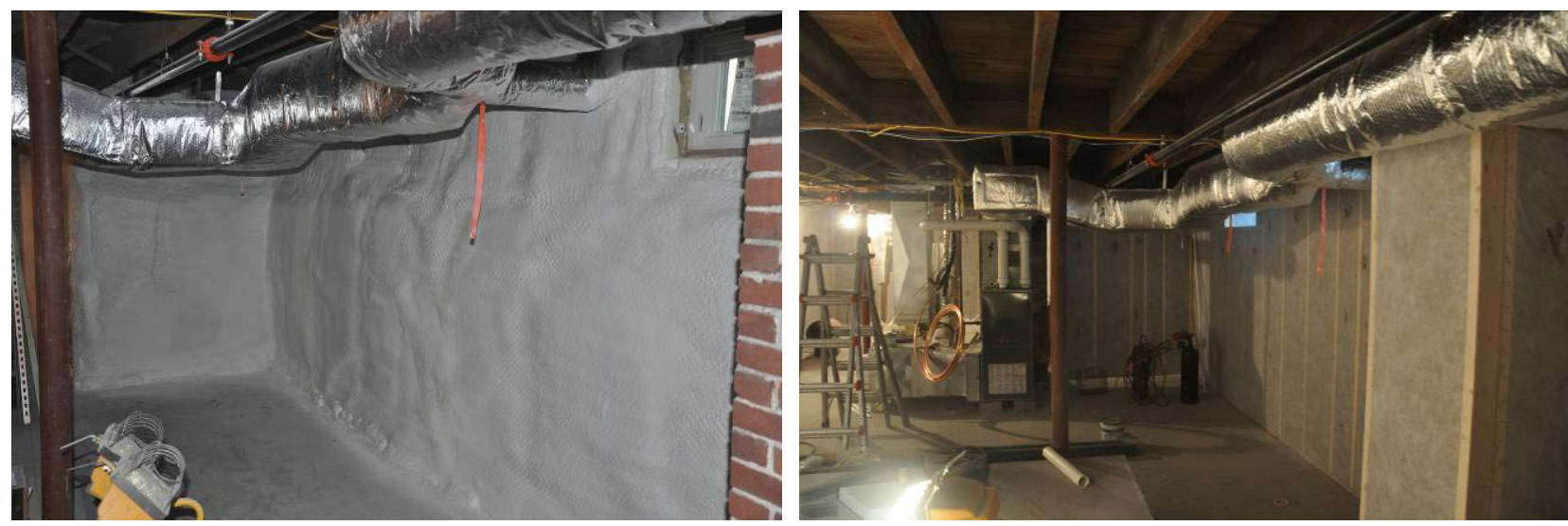

Figure 25. Basement with spray foam (L); and added cellulose in framed wall (R)

The ratio of spray foam (air impermeable insulation) to fibrous fill insulation (air permeable insulation) must be such that interior-sourced condensation does not occur on the surface of the spray foam. Reasonable guidance is to apply the ratios (shown by climate zone) provided in IRC Table R601.3.1 (Class III Vapor Retarders) (ICC 2009). 


\subsection{Flat Surface Walls}

On walls with relatively flat surfaces (such as cast concrete or CMU block), rigid plastic foam insulation can be used in lieu of closed cell spray foam, as it is a moisture-tolerant airimpermeable insulation material. Several variants are shown below and all of them include the following as part of their design:

- Rigid board foam is installed against the foundation wall, wrapping up onto the top of the wall.

- There is a provision for drainage behind the foam, down into some type of perimeter drainage system.

It is vital in all cases that the drainage space behind the foam be airtight and isolated from the interior space. This includes sealing all seams between boards (tape, expanding foam, sealant), connections to other air barrier elements (slab, rim joist), and any mechanical penetrations through foundation walls (gas, water, and DWV lines). Airtightness needs to be a part of the quality control and quality assurance process.

Figure 26 uses foil-faced polyisocyanurate foam that is rated to be left exposed in a crawl space (see crawl space requirements IRC R316.5.4, under Section 2.4.3 "Fire Protection

Requirements." Drainage is provided by a "spacer" mesh behind the foam; bulk water drainage is directed into the gravel field under the slab.

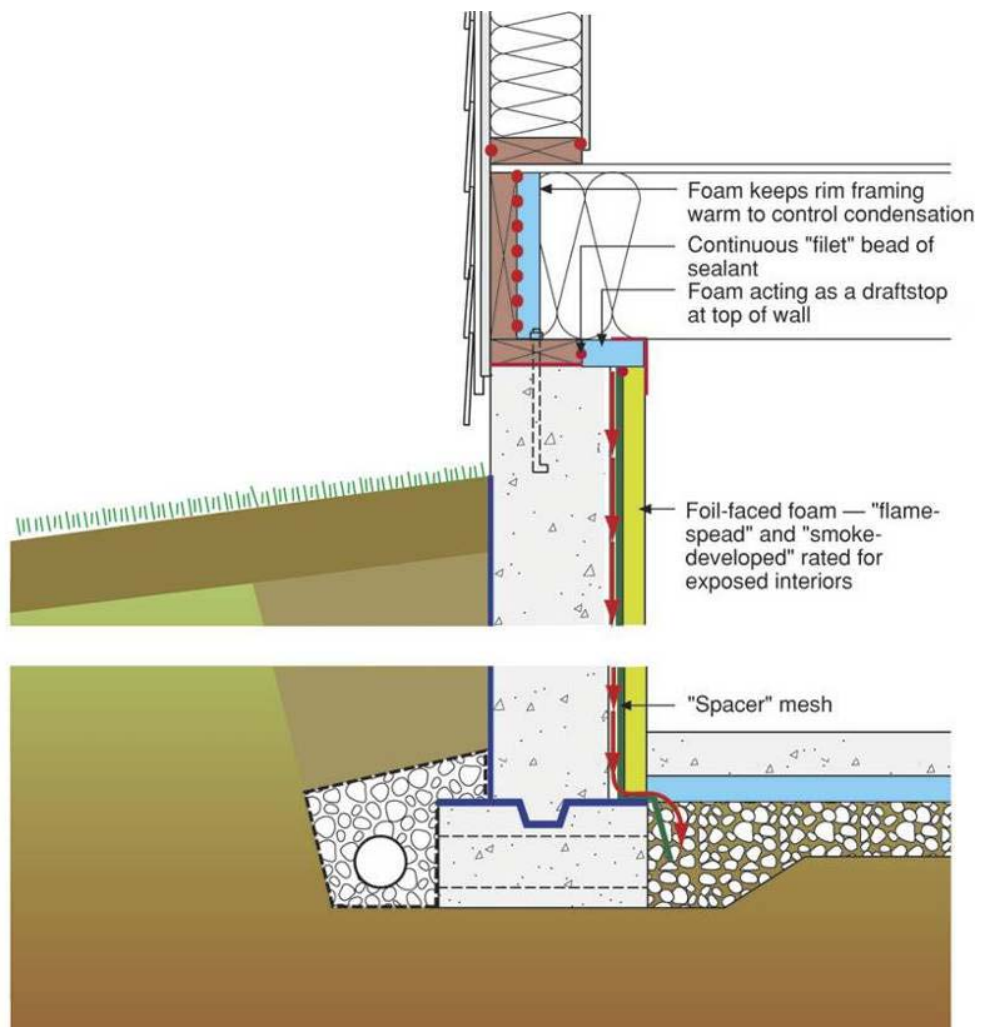

Figure 26. Interior drainage; new or retrofit construction (non-rubble walls); foil-faced foam 
Note that this detail is shown with a newly cast insulated slab, and that the gravel field under the slab is connected to the exterior footing drain with lateral connector pipes. If this is being retrofitted to an existing slab, these connections would not exist: therefore, demolition, excavation, and the addition of an interior perimeter drain would be needed (Figure 27). Air barrier continuity is essential (as discussed above): critical joints include the top of the drainage mesh space, and making the rigid foam a continuous barrier (tape and sealant beads).

Another approach is to use an air gap membrane to provide drainage, as shown in Figure 27 . The air gap membrane is terminated into a retrofitted interior perimeter drain directed to a sump or daylight. The foam is attached to the foundation with $1 \times 2$ horizontal strapping, which in turn provides attachment for the interior gypsum board, and a space for service distribution. Note that this case uses extruded polystyrene rigid foam that is not rated for exposure; therefore, interior gypsum board is used as a thermal barrier/ignition barrier (basement/crawl space).

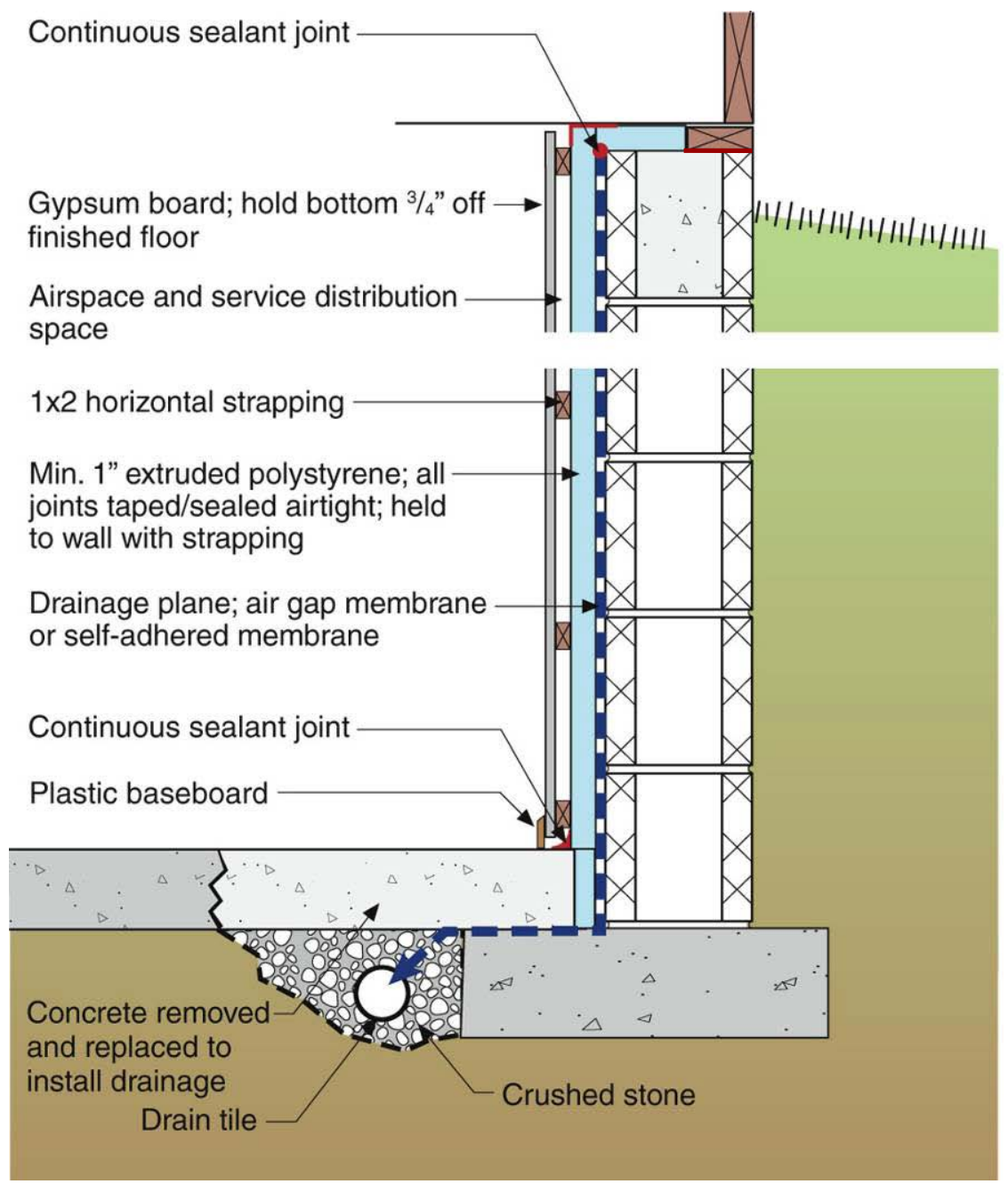

Figure 27. Interior drainage; new or retrofit construction (non-rubble walls); foam covered with gypsum board

Air barrier detailing is required at all foam joints, the slab connection, and the rim joist termination. The drainage space must be sealed at its top termination to prevent venting of the sub-slab air into the conditioned space. 
It should be noted that some manufacturers have conducted testing allowing them to leave extruded polystyrene (XPS) insulation exposed in limited-access crawl spaces.

Another alternate to using a spacer mesh or an air gap membrane is to use commercially available rigid foam boards (XPS) that have a filter fabric-covered pattern of channels cut on one face, to allow for drainage.

Capillary break issues under wood framing members in contact with masonry should be addressed. Note that Figure 26 and Figure 27 show dimension lumber framing with an existing sill gasket/capillary break.

\subsection{Partial Drainage Detail}

As shown in Figure 13, bulk water drainage often occurs through the field of a rubble stone wall. This property can be leveraged, especially in "mostly dry" basements, by using only a limited height of drainage, as shown in Figure 28. This system was used at the "Concord House" project (see Section 7 "Field Survey Work" and Lstiburek 2010a). The assembly is a $3 / 4$ in. (19 mm) mesh drainage mat material, with an attached filter fabric facing upwards and inwards. The material is run over the existing slab and up the wall roughly one foot $(305 \mathrm{~mm})$.

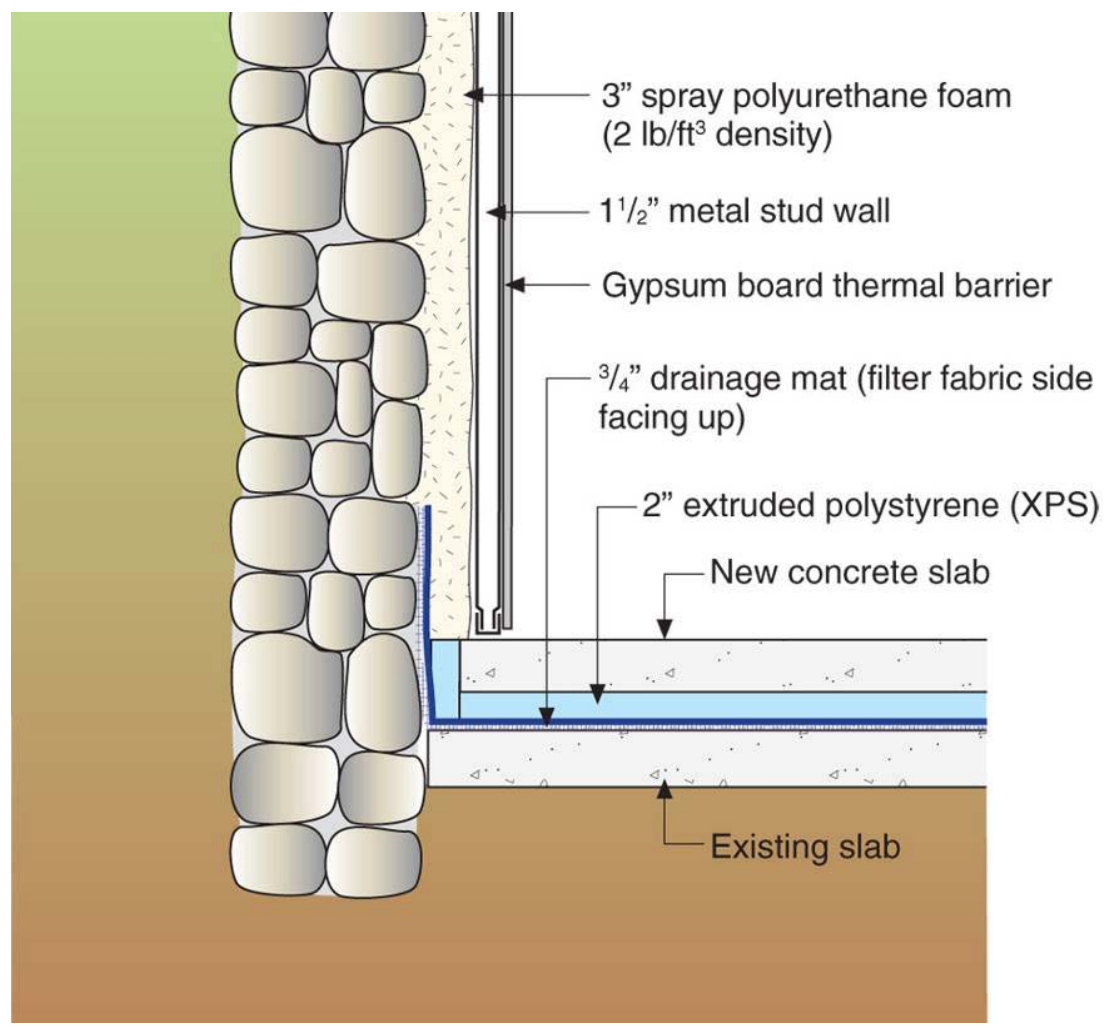

Figure 28. Drainage mat sub-slab detail; terminates at slab perimeter to collect bulk water

In this system, closed cell spray foam is applied to the foundation wall: its moisture tolerant properties allow it to be used as a drainage plane without an additional drainage layer. The foam itself is sufficiently rigid to support itself if it is between 2 and $3 \mathrm{in}$. (51 and $76 \mathrm{~mm}$ ) thick, and if it adheres to the wood frame at the top of the foundation and the edge of the foam "bathtub" at the bottom of the foundation. 
Instead of an interior perimeter drain, the $3 / 4$ " $(19 \mathrm{~mm})$ mesh is used to provide a drainage space that drains on top of the original slab, into a sump cut into the slab. This step eliminates the demolition and reconstruction of a slab, and the need for a granular fill/gravel field, assuming that head height is available. Note that an air gap membrane could be used as a replacement for the mesh drainage mat. Extruded polystyrene insulation and a new concrete slab are placed on top of the drainage layer. Further details of the edge termination are shown in Figure 29.
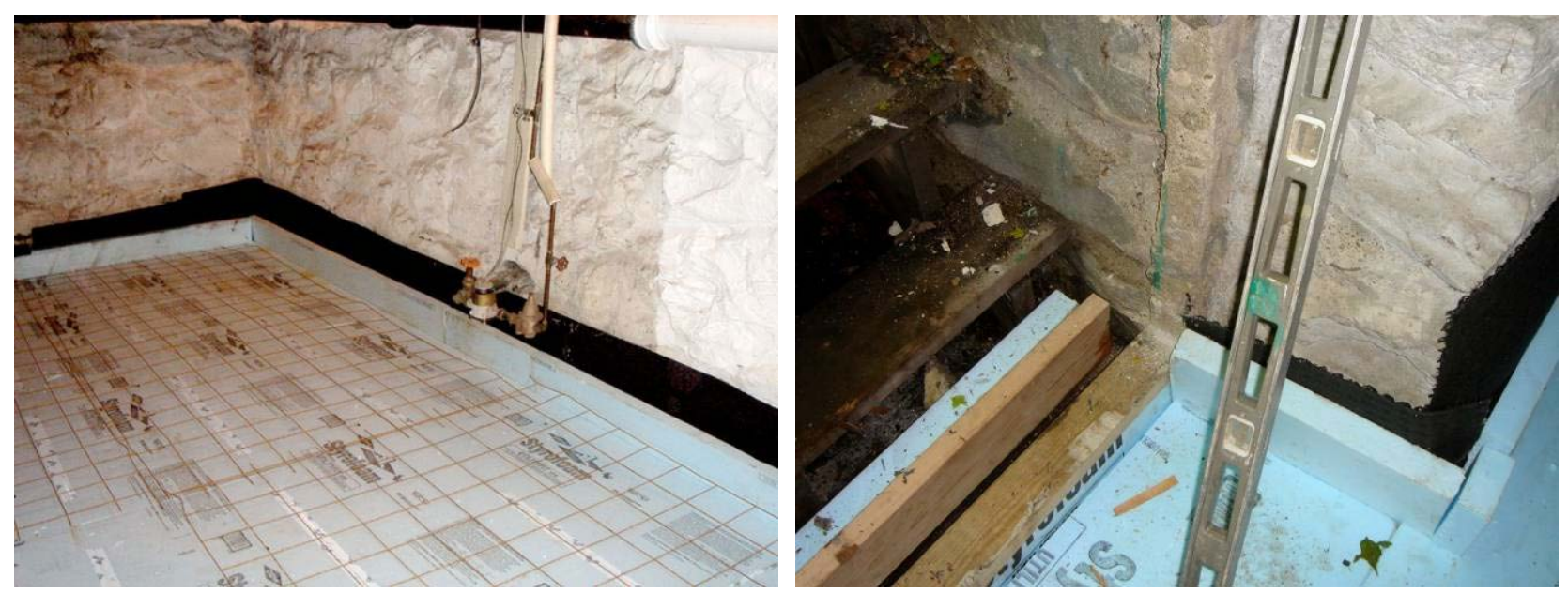

Figure 29. Basement slab insulation, and edge drainage mat detail continuing under slab

Note that the sump must have perforations or connections to the edge of the drainage mat air space, to allow for water collection from this space and relief of hydrostatic head pressure. Otherwise, bulk water can accumulate within the drainage mat (over the slab), and if sufficient water is collected, this can flood to the interior.

Note that a continuous air barrier at the drainage space is vital: one failure noted during commissioning was the termination of the drainage mat at the interior chimney (Figure 30).
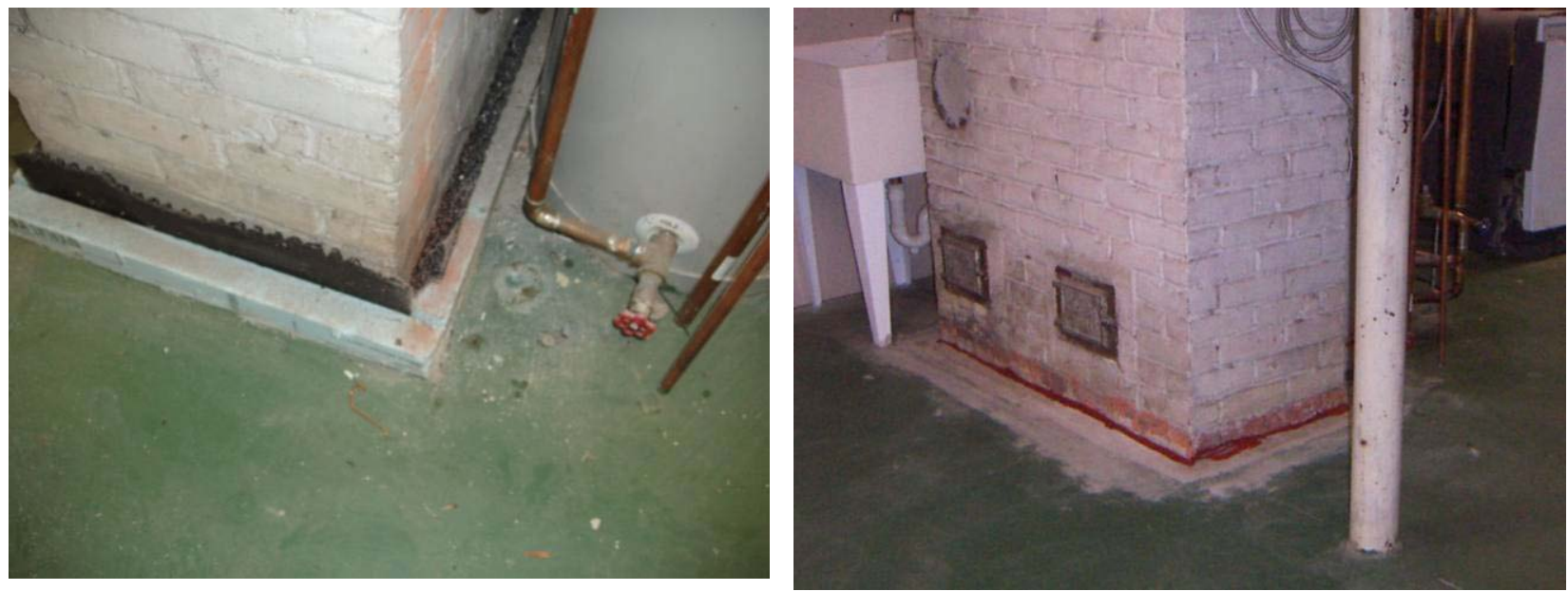

Figure 30. Drainage mat penetration at chimney; retrofit sealing of drainage mat

Substantial air leakage was noted at this penetration during testing, showing that air leakage would occur in operation. The drainage mat was cut and sealed, resulting in a measurable reduction in air leakage. 


\subsection{Non-Drained Spray Foam Wall Detail}

There are foundations that might be considered "substantially dry," with no known history of water leakage during their service life, and/or known good exterior water control (large overhangs, free draining soil, and/or exterior water control layers). In these cases, a judgment call can be made to omit any drainage layer, and spray the ccSPF directly against the foundation wall. Note that ccSPF material provides adequate vapor and air control, and that it can withstand some incidental wetting due to its moisture-tolerant properties. An example is shown below in Figure 31.

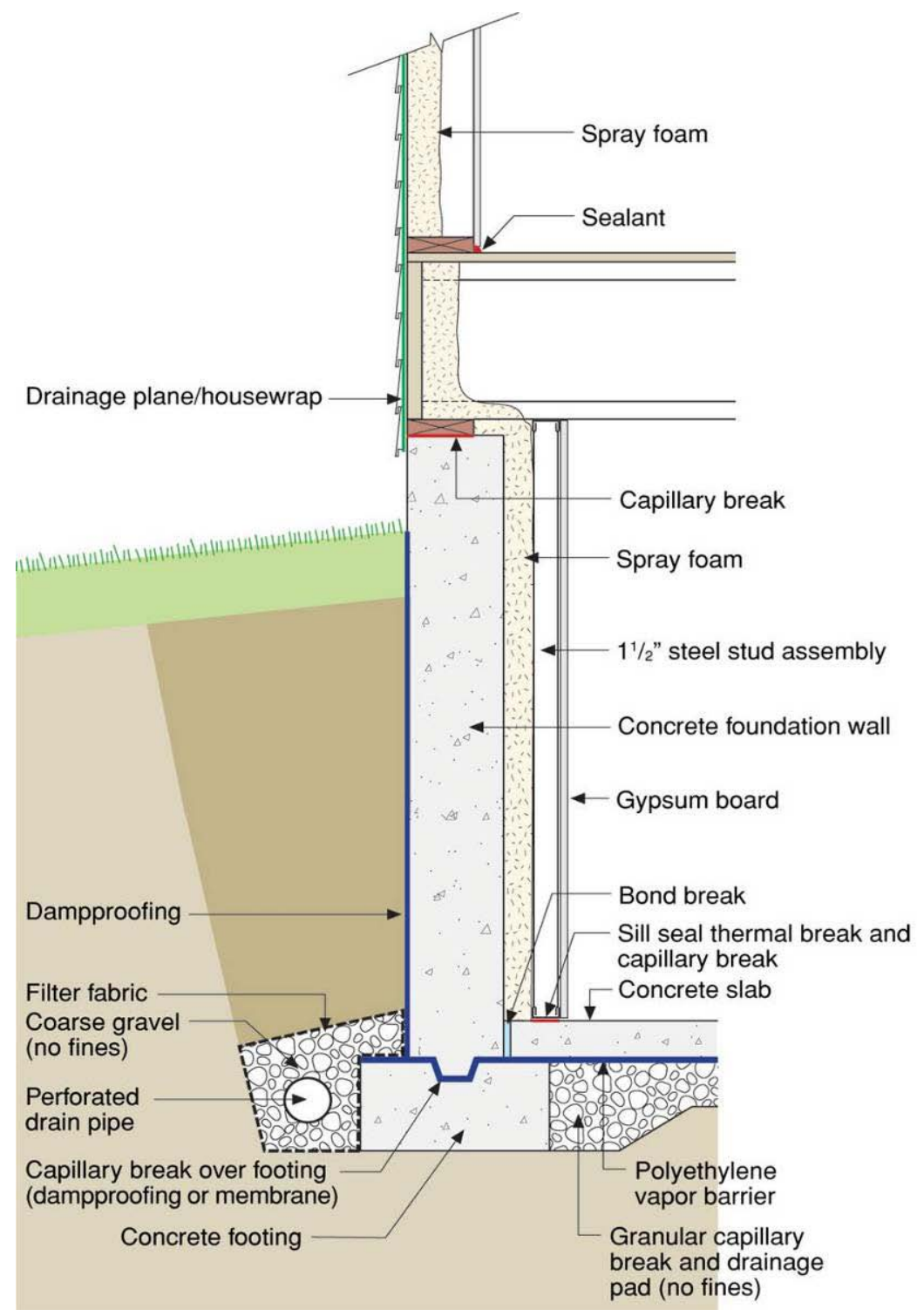

Figure 31. ccSPF wall insulation with no drainage layer (dry basement); no slab insulation

The spray foam forms a continuous seal from the underside of the first floor deck to the slab. As with previous work, if steel framing is used, it must be kept out of the foam to avoid a degradation of R value. Alternately, an intumescent paint coating could be used in lieu of the gypsum board, if a finished appearance is not required. Note that this is the basement insulation design examined in Section 8 "Field Monitoring." 


\subsection{Spray Foam "Bathtub" Design}

A further development on the previous spray foam wall detail is to continue the spray foam onto the existing slab, to form a complete "bathtub" of spray foam. One builder who is implementing this type of foundation design is a builder partner in our retrofit work, under TO 2 Task 8.2 (Byggmeister). This detail dispenses with separate details for insulation of the slab and intentional drainage, and so is best suited for substantially dry basements, depending on risk tolerance and use of the basement.

In order to implement the system, the basement must first be prepared by removing debris and loose material. If existing moisture-sensitive (wood) partitions are to be retained, they must be detailed to allow for being embedded in a high humidity environment. This was implemented by replacing the bottom plate with rigid foam and a pressure treated bottom plate, as shown in Figure 32.
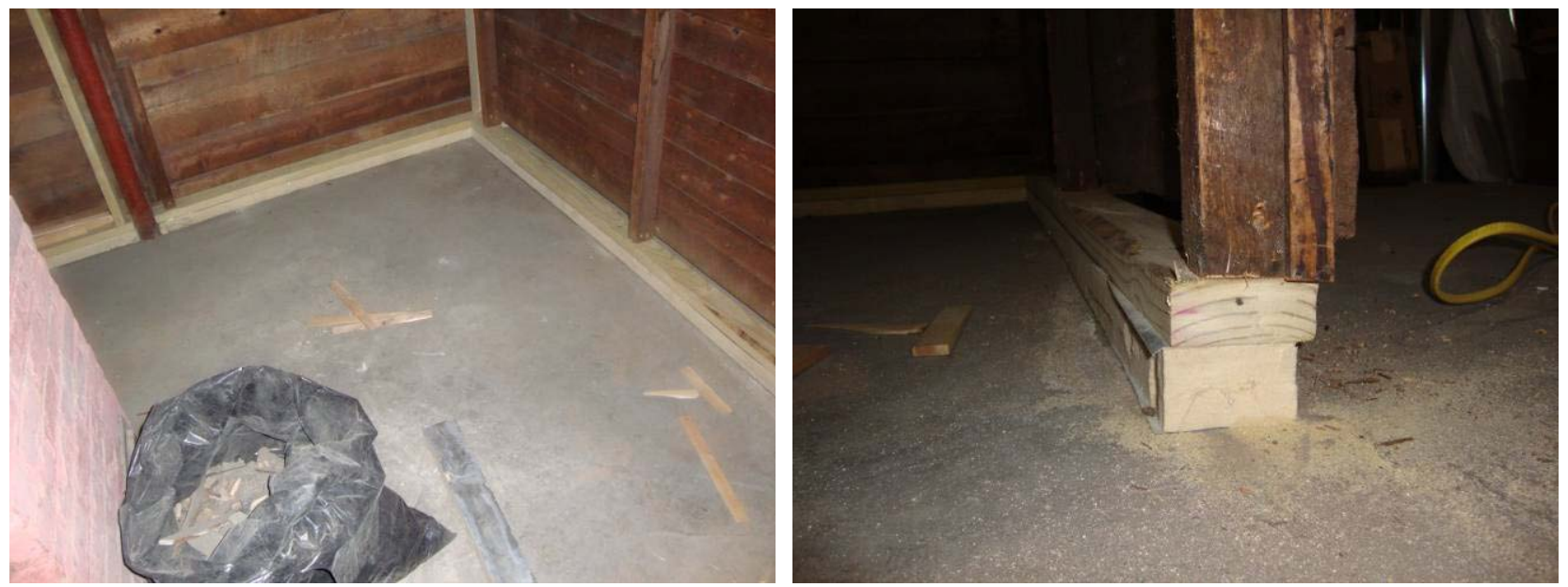

Figure 32. Modification of existing partitions (๑ 2011 by Byggmeister; reprinted with permission)

Then, closed cell spray foam is applied to the walls and onto the existing slab/earth, to form a monolithic layer on all basement surfaces (Figure 33). It forms a continuous barrier for heat flow, air flow, and water vapor diffusion control.

A slab is then cast on top of the spray foam floor (Figure 34); note that the spray foam forms effective edge insulation (and a bond break) for the slab. Interior walls are framed and gypsum board is installed. 

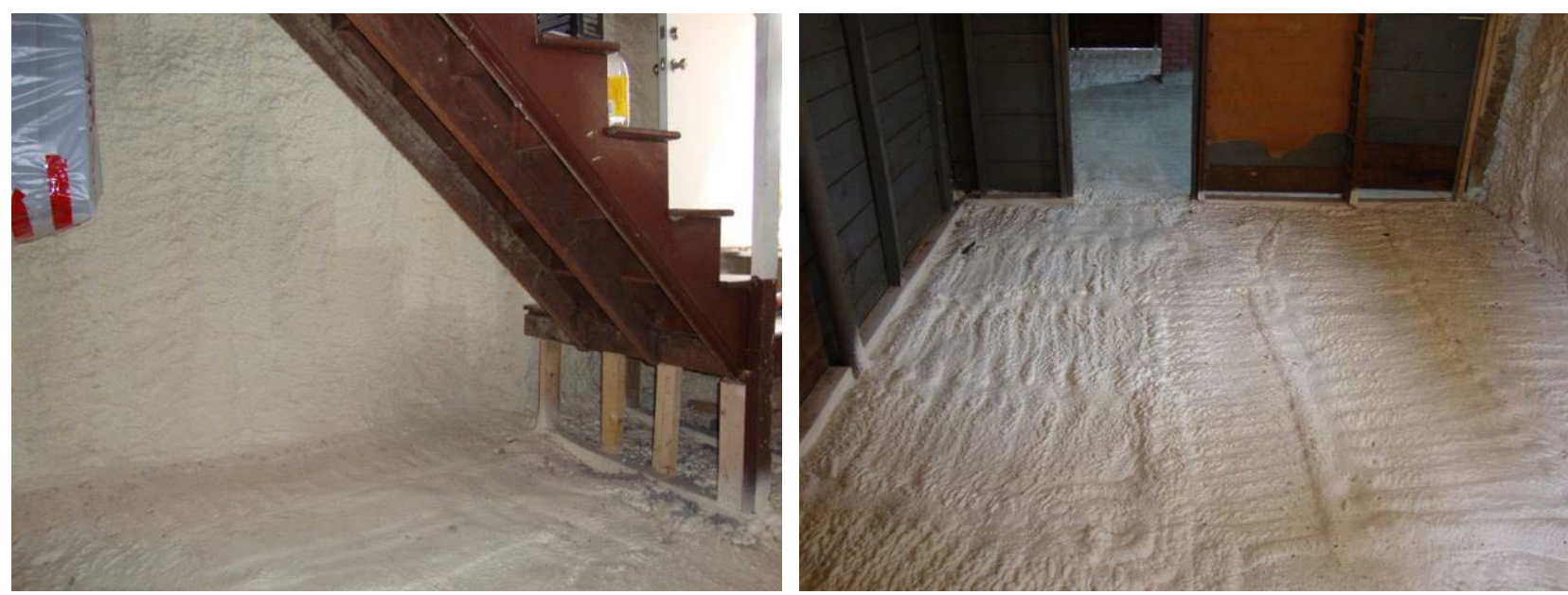

Figure 33. Spray foam applied to walls and slab (๑ 2011 by Byggmeister; reprinted with permission)
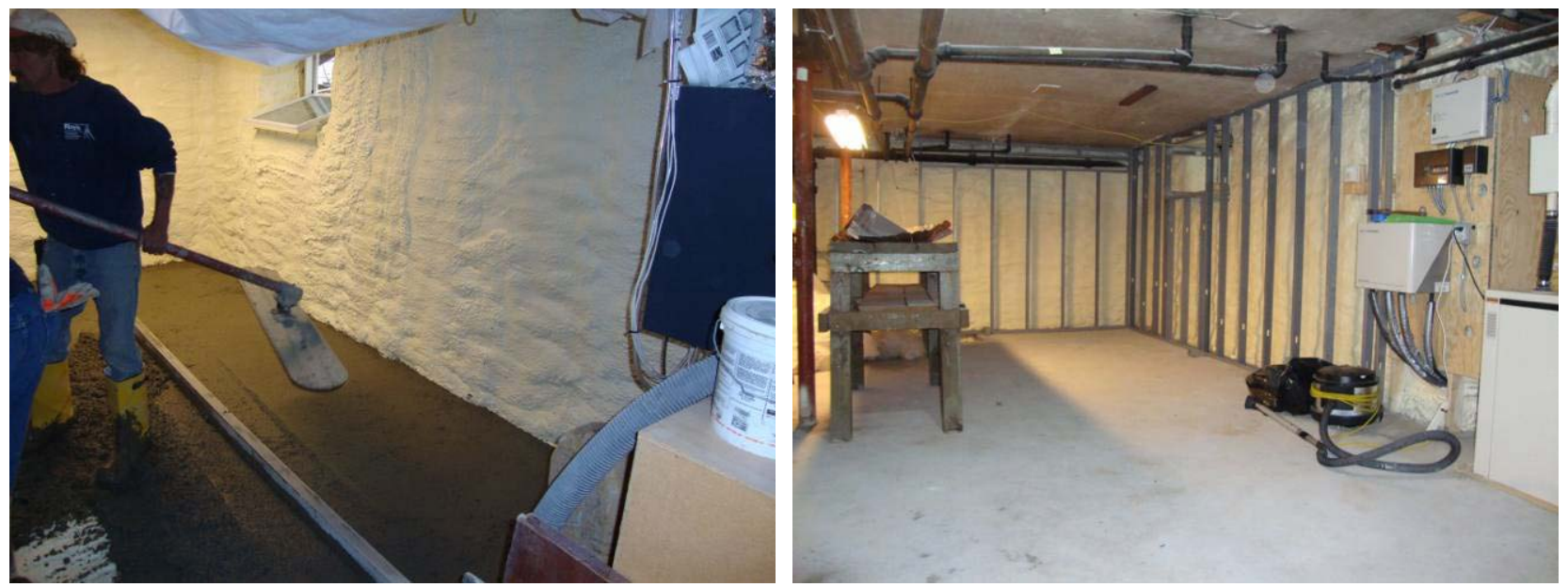

Figure 34. Casting of slab; wall framing (@ 2011 by Byggmeister; reprinted with permission)

The use of spray foam as slab insulation may seem unorthodox; however, there has been published trade literature on using closed cell spray foam as sub-slab insulation in new construction basements (Pindell 2010). The article's author (a New England-area spray foam contractor) points out a variety of benefits of ccSPF over rigid board stock foam for sub-slab insulation. Advantages of ccSPF include its monolithic properties (no seams), ability to seal at plumbing or other penetrations through the slab, forgiveness of irregularities in substrate, and lack of waste (cutoffs). However, research is warranted on long-term moisture adsorption in this horizontal application (i.e., risks associated with continuous bulk water immersion).

The author provides an installed cost of $\$ 2.20$ /square foot for a 2 " thick slab installation ( $\sim \mathrm{R}$ $12 /$ RSI 2.1), and a comparative installed cost of 2"/51 mm XPS at $\$ 1.80$ (R-10/RSI 1.8). The recommended installation is over properly compacted gravel fill (no polyethylene vapor barrier underneath); the foam is installed in 1" lifts.

Testing has revealed that the air barrier at the basement is exceptional, as would be expected with this type of installation. 
Field experience with this system to date has been excellent. During an extreme rain event, some incidental water leakage was reported in one basement. This is to be expected: imperfections in the spray foam are probable even in these seemingly monolithic applications. If necessary, this system could be combined with any of the drainage layer options discussed previously (air gap membrane, drainage mesh, interior perimeter drainage). This layer should relieve the hydrostatic head buildup behind the foam, thus preventing penetration of water leakage to the interior.

In general, it is a judgment call to determine the level of acceptable risk vs. the cost of the system, and whether the goal is to allow for some periodic wetting, or if perfect control of basement water is required. This would be a function of risk tolerance, and (for instance) the application of the basement space (e.g., storage and mechanical equipment vs. finished media room or library). In addition, the ability to dry the space should be considered when balancing risks. An unfinished slab and paperless gypsum board has minimal risks, while a finished space with paper faced gypsum would be at a higher risk.

\subsection{Slab Options}

The previous sections have shown a variety of floor slab treatments and this section attempts to list them in a more deliberate manner. Note that this is not meant to be an exhaustive list, but only to provide additional guidance when choosing strategies.

This discussion is meant to only cover walkable slab surfaces, as opposed to crawl spaces with a polyethylene ground cover as a floor. Crawl space ground covers are discussed in detail by Tooley $(2003,2004)$.

All slabs require a capillary break (granular fill/gravel, polyethylene, or non-capillary active material such as ccSPF or XPS), vapor control, and a continuous air barrier. Note that some of these measures are made more difficult in retrofit situations, as discussed below.

A common question is whether or not to insulate a basement slab. Energy modeling typically shows a miniscule heating benefit (and cooling penalty) for insulating a basement slab. It is wellconnected to deep earth temperatures (closer to the range of $50^{\circ} \mathrm{F} / 10^{\circ} \mathrm{C}$ than to exterior temperatures; Hutcheon and Handegord 1995), so it does not see temperature extremes. However, insulating basement slabs helps prevent moisture problems which commonly occur due to carpets or storage boxes on the floor. The carpet or box acts as insulation, cooling the slab beneath. The area under the carpet is at the same dewpoint as the basement, but at a lower temperature: this causes high humidity levels under the carpet, and the potential for mold growth. Sub-slab insulation eliminates the problem, by providing the majority of the temperature drop under the slab; therefore, the insulation effect of the carpet or box is small, and the moisture problem is eliminated.

If the slab is insulated, one vital detail is a thermal break at the slab edge, to avoid thermal bridging from the foundation wall to the slab, resulting in a cold edge/corner. Its installation depends on when in the construction sequence the slab is cast, relative to insulation of the wall. If the wall insulation is installed before slab insulation, it can be run down the wall, and the thermal break is already formed (Figure 22, Figure 26). But if slab is cast first, a thermal break needs to be incorporated in the slab design (Figure 27, Figure 28). 


\subsubsection{Listing of Options}

Some options covered in the figures above include the following:

Demolish slab and rebuild (insulated): This is the most straightforward option, as it is similar to construction of a new slab. Granular drainage is installed on the existing ground (if not already present) as a capillary break, which is followed by rigid foam insulation (extruded polystyrene typical; expanded polystyrene and closed cell spray foam are other options), polyethylene vapor barrier (primarily to ensure air barrier continuity with rigid foam boards), and cast concrete. An interior perimeter drain can be provided in the granular drainage layer, which is highly recommended, given the small incremental cost of this measure.

Demolish slab and rebuild (uninsulated): This is similar to the previous assembly, except that rigid foam insulation is omitted. An example is shown in Figure 31. This option has some moisture risks, as the slab surface will be significantly cooler than basement conditions, as it is thermally coupled to the soil. As a result, items covering the floor (carpeting, boxes, etc.) will cause localized cooling, resulting in higher localized relative humidity and condensation risks.

Existing slab (insulated): If the existing slab is to be retained, the control functions described above must be provided by the topside assembly. In addition, many existing slabs have no capillary break (i.e., concrete in direct contact with wet earth, no polyethylene), so moisture loading through the slab must be controlled. One example is Figure 28: the drainage mesh provides a capillary break and drainage space, and the XPS and concrete slab act as the air barrier layer.

The ccSPF "bathtub" floor slab also provides insulation, a capillary break, and an air barrier.

Another alternate is described below in Section 4.7.2, "Floating Insulated Slab Retrofit," which isolates the slab with an airtight and vapor-impermeable layer (air gap membrane), adds rigid foam insulation, and provides a walking surface above.

Existing slab (uninsulated): The lowest cost/minimal approach would be to leave the existing slab in place, and to simply provide moisture control measures. This assumes that the existing slab has no capillary break, and will be a moisture source. This is critical because after the retrofit, the basement space will be more airtight than previous conditions. Therefore, moisture released from the floor can have a greater effect on interior humidity levels.

If the existing slab is to be left exposed, all seams must be sealed with a concrete-compatible caulk to create an effective air barrier (urethane caulk typical; backer rod used on cracks $1 / 4$ " or wider). The water vapor emission rate must be reduced with some type of sealer, such as epoxy paint (Figure 17).

The alternate assembly described in Section 4.7.2, "Floating Insulated Slab Retrofit," is also usable without the insulation layer, assuming that the air gap membrane can be made airtight.

Perimeter drainage: Note that in both cases of retaining the existing slab, if perimeter drainage is used (Figure 17 and Figure 27), the perimeter of the slab must be demolished and excavated to install granular fill and a drainage system (as per Figure 27). 


\subsubsection{Floating Insulated Slab Retrofit}

If a basement is being used only for storage, mechanical equipment, and secondary services (e.g., laundry), a relatively low-cost basement retrofit assembly is shown below in Figure 35 and Figure 36, which was developed by Camroden Associates. The assembly is composed of:

- Existing basement slab; add leveling if required or desired.

- Air gap membrane (a.k.a. "dimple mat"): provides air barrier (all seams must be sealed; material must be terminated in an airtight manner at perimeter) and vapor control from slab/ground. It is critical that this seal must be airtight; the air space conditions under the membrane will often be at 100\% RH (see Figure 36), and have poor air quality.

- Rigid foam insulation (extruded polystyrene); R-10 (2"/51 mm XPS) typical

- Cement tile backer board as a walking surface, loose laid onto assembly, and cut around obstructions. This material is an improvement over plywood or OSB subflooring for several reasons. It is non-moisture sensitive, given the likelihood of moisture problems and flooding in basements. It also does not have the rigidity of plywood, and therefore mostly conforms to uneven surfaces below. Based on our experience to date, adhesion of the cement board is not necessary to prevent shifting. In addition, leaving the cement board loose-laid allows simple removal in case of bulk water events, or for inspection of conditions under the floor assembly.
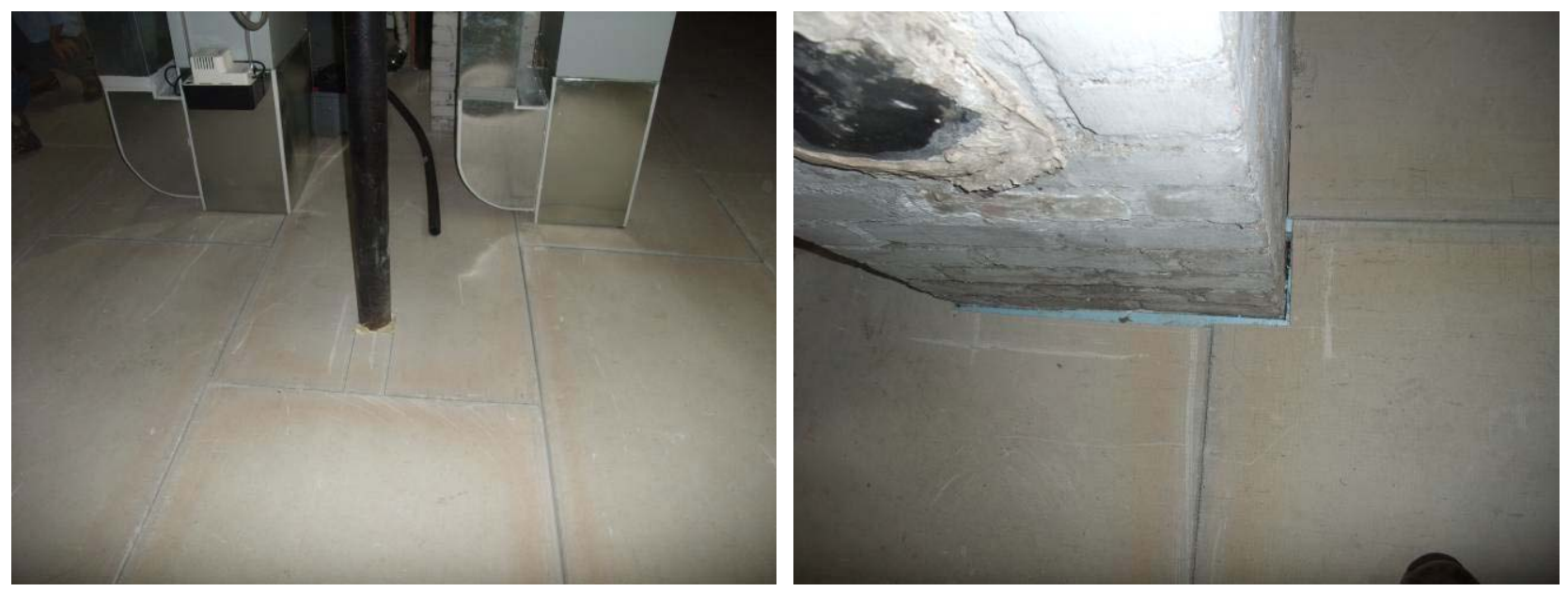

Figure 35. Storage use basement slab insulation/moisture control retrofit; cement board surface

If it is acceptable to increase the risk of damage to moisture-sensitive materials (e.g., boxes) stored on the surface, the insulation layer may be omitted. However, there is some minimal R value associated with the air gap membrane, even though it is bridged by dimples (roughly R1/RSI 0.2), so it provides some thermal break from the concrete slab. 


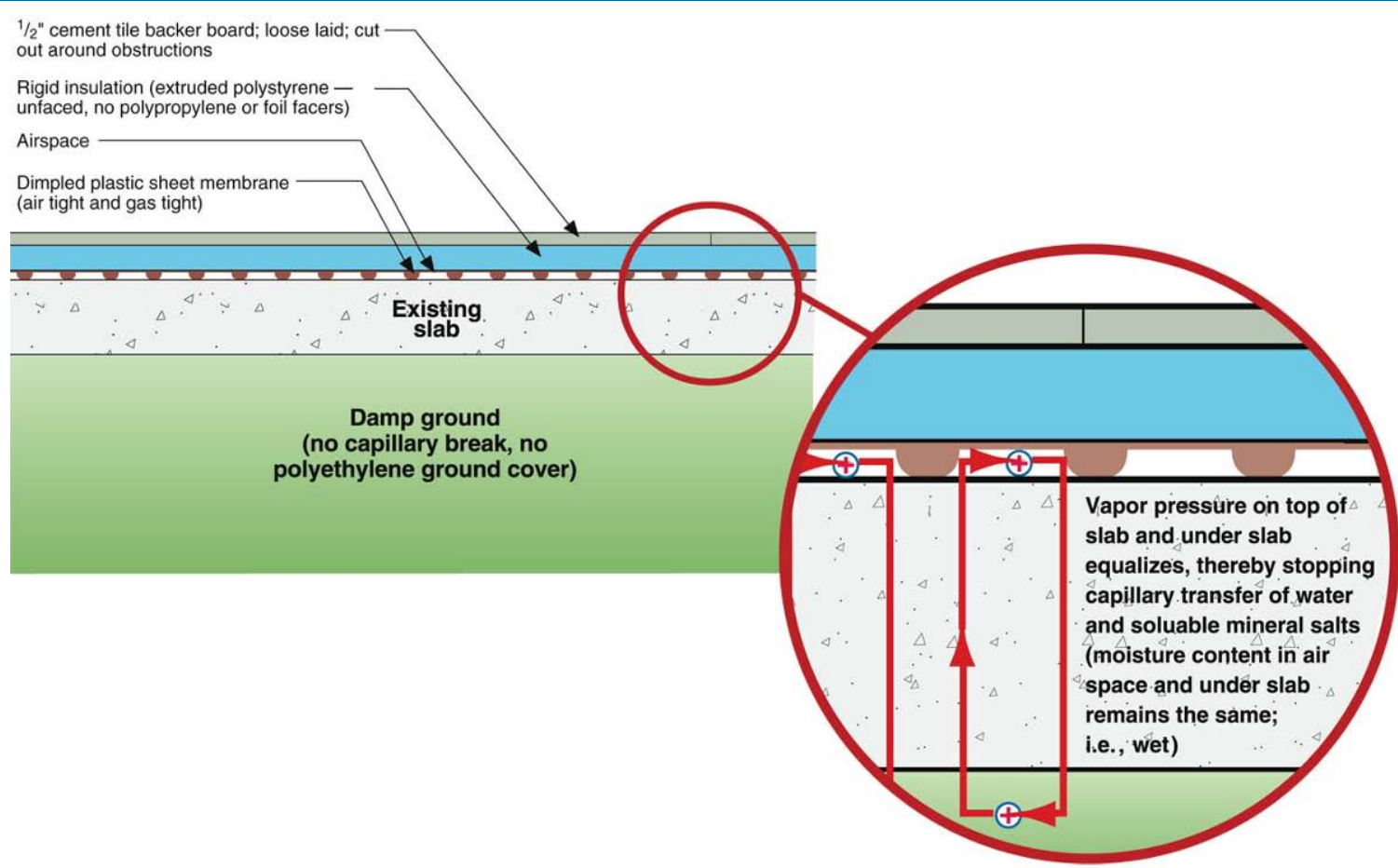

Figure 36. Use of air gap membrane and insulation as a "wet slab" retrofit

\subsection{Installed System Costs}

Some limited cost information was made available by a New England-area contractor who has installed several of these basement insulation/water control assemblies in retrofit projects. It is presented in Table 2 below and stated in terms of installed cost. In addition, information from Building Envelope Services Inc. and the trade literature (Pindell 2010) is included in the table. Of course, this is a limited database of information; costs will vary between contractors, regions and specific situations.

Table 2. Available Installed Cost Information on Foundation Retrofit Options

\begin{tabular}{|c|c|c|c|}
\hline Item & Cost & Cost Metric & Notes \\
\hline $\begin{array}{l}\text { AVID } \\
\text { (Air/Vapor/Insulation/ } \\
\text { Drainage System) }\end{array}$ & $\sim \$ 4$ & $\begin{array}{l}\text { Per square foot } \\
\text { wall area }\end{array}$ & $\begin{array}{l}\sim \$ 2 / \text { sf floor area for } 4 \\
\text { crawl space (Bldg. Env. } \\
\text { Services 2011) }\end{array}$ \\
\hline $\begin{array}{l}\text { ccSPF wall retrofit, no } \\
\text { drainage, } R-20 \text {, intumescent } \\
\text { paint interior }\end{array}$ & $\$ 5-\$ 7$ & $\begin{array}{c}\text { Per square foot } \\
\text { wall area }\end{array}$ & \\
\hline $\begin{array}{l}\text { ccSPF wall retrofit, no } \\
\text { drainage, R-20, stud wall \& } \\
\text { gypsum interior }\end{array}$ & $\$ 10-\$ 11$ & $\begin{array}{l}\text { Per square foot } \\
\text { wall area }\end{array}$ & \\
\hline Spray foam installed cost & $\$ 1.00-\$ 1.50$ & Per board foot & \\
\hline Perimeter drains & $\$ 20-\$ 40$ & Per lineal foot & \\
\hline $\begin{array}{l}\text { "Rat Slab" } \\
\text { (2" thick concrete slab) }\end{array}$ & $\$ 3.25-\$ 4.00$ & $\begin{array}{l}\text { Per square foot } \\
\text { floor area }\end{array}$ & \\
\hline
\end{tabular}




\begin{tabular}{|c|c|c|c|}
\hline Item & Cost & Cost Metric & Notes \\
\hline Drainage mat on floor & $\$ 0.50$ & $\begin{array}{l}\text { Per square foot } \\
\text { floor area }\end{array}$ & \\
\hline $\begin{array}{l}\text { Spray foam sub-slab } \\
\text { insulation }(2 " / \mathrm{R}-12)\end{array}$ & $\$ 2.20$ & $\begin{array}{l}\text { Per square foot } \\
\text { floor area }\end{array}$ & (Pindell 2010) \\
\hline $\begin{array}{l}\text { XPS sub-slab insulation } \\
(2 " / \mathrm{R}-10)\end{array}$ & $\$ 1.80$ & $\begin{array}{l}\text { Per square foot } \\
\text { floor area }\end{array}$ & (Pindell 2010) \\
\hline
\end{tabular}

The installed costs of these retrofits are admittedly high. However, the cost must not be solely compared to the cost of an insulation retrofit (with associated payback calculations). Instead, it must also be viewed as an interior bulk water management system, which also reduces humidity loads to the interior. There are a variety of options for foundation insulation in substantially dry basements, but unfortunately, more costly options are required to insulate a wet basement in a moisture-safe manner that provides good indoor air quality.

\subsection{Flowchart}

To assist the decision-making process of choosing between these variants, the following flowchart provides some rough guidelines on why certain options should be chosen over others in given cases. This should not be regarded as an absolute set of rules; user judgment is required in these decisions. 


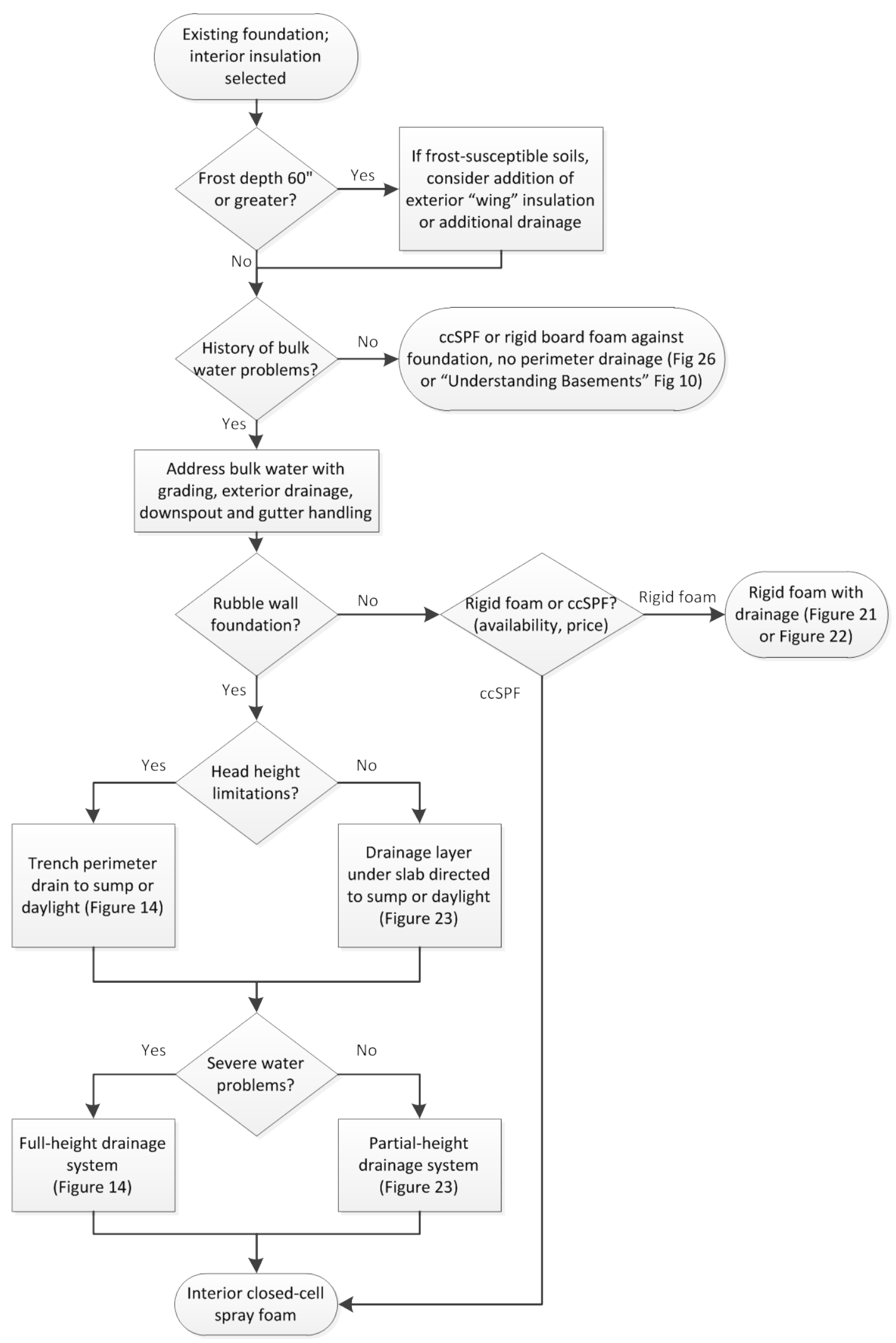

Figure 37. Flowchart for interior foundation insulation options and water control 


\subsection{Critical Takeaways}

The post-retrofit basement will be more airtight, and combustion safety measures will need to be addressed for any fuel-burning appliance located in the basement/crawl space. This can include switching to sealed combustion appliances, or adding combustion air measures.

Another effect of increased airtightness is that radon can have greater accumulation rates. In locations with high radon levels, testing is recommended.

For a historically wet basement, the recommended assembly consists of interior drainage (to an interior perimeter drain), and interior ccSPF insulation. Alternately, with flat walls, rigid foam can be used instead of ccSPF. Several critical details are required for durability and IAQ.

The cold foundation wall surface must be isolated from interior air to avoid condensation issues.

The drainage space must be isolated from interior air to avoid indoor air quality and moisture buildup issues (air barrier requirement).

The drainage space must not be "vented" into (or connected to) moisture sensitive materials, such as wood beams or sill plates.

A "partial drainage" system can be used with rubble stone walls, relying on water drainage through the wall itself.

In historically dry basements, closed cell spray foam or rigid foam plastic can be used directly against the foundation wall. It provides adequate vapor and air control, and can withstand some incidental wetting due to its moisture-tolerant properties.

Basement slab insulation has limited energy benefits, but has advantages for moisture and condensation control, and storage of moisture-sensitive materials in basements. 


\section{Hygrothermal Simulations}

The hygrothermal behavior of the foundation walls, before and after insulation with closed cell spray foam, is a matter of further investigation. For instance, field experience indicates that this insulation system greatly reduces the entry of water vapor into the basement; rough quantification of this effect would be useful. Also, there are damage functions that occur due to water "wicking" (capillarity) through foundations, such as efflorescence and mortar erosion (Lstiburek 2007). Quantifying these damage functions helps gauge the risk of the retrofitted assembly.

\subsection{Model Setup}

The WUFI 5.1 Pro (Künzel 2010) computer model was used to simulate the effects of insulating the walls on the moisture and temperature conditions of the foundation walls. WUFI is one of the most advanced commercially available hygrothermal moisture programs in use today. Its accuracy has been verified (by the Fraunhofer-Institut für Bauphysik in Holzkirchen, Germany www.wufi.de) against numerous full-scale field studies of enclosure performance (roofs, walls, foundations, parking garage decks, etc.) over a number of years. Much of the field verification work supporting the model has been solid masonry and stone wall systems.

For the foundation wall, a section of concrete ( 0.5 water to cement ratio, from the default WUFI database) 8 inches $(0.2 \mathrm{~m})$ thick was simulated. Concrete was used (as opposed to various masonry and mortar combinations) as a simplification, and because a non-homogeneous assembly will have very different results depending on whether stone or mortar is simulated. Weather files were developed to provide boundary conditions for both sides, as listed below in Table 3.

Table 3. List of Boundary Conditions for WUFI Foundation Simulations

\begin{tabular}{lcccc}
\hline & $\begin{array}{c}\text { Exterior } \\
\text { Temperature }\end{array}$ & $\begin{array}{c}\text { Exterior } \\
\text { Moisture }\end{array}$ & $\begin{array}{c}\text { Interior } \\
\text { Temperature }\end{array}$ & $\begin{array}{c}\text { Interior } \\
\text { Moisture }\end{array}$ \\
\hline $\begin{array}{l}\text { Constant Interior } \\
\text { T/RH }\end{array}$ & $59^{\circ} \mathrm{F} / 15^{\circ} \mathrm{C}$ & $\begin{array}{c}0.4 \text { inches } / 10 \\
\text { mm rainfall/ }\end{array}$ & $68^{\circ} \mathrm{F} / 20^{\circ} \mathrm{C}$ & $50 \% \mathrm{RH}$ \\
& & $100 \% \mathrm{RH}$ & & \\
Variable Interior & $59^{\circ} \mathrm{F} / 15^{\circ} \mathrm{C}$ & 0.4 inches $/ 10$ & $61^{\circ} \mathrm{F} / 16^{\circ} \mathrm{C}$ to & $50 \% \mathrm{RH}$ to $70 \%$ \\
T/RH & & mm rainfall/ & $68^{\circ} \mathrm{F} / 20^{\circ} \mathrm{C}$ & $\mathrm{RH}$ (sinusoidal) \\
& & $100 \% \mathrm{RH}$ & (sinusoidal) & \\
\hline
\end{tabular}

The exterior side is meant to represent the boundary conditions in the soil. The worst case condition of capillary contact (bulk water/wet conditions) on the exterior of the foundation wall with no dampproofing (typical for older foundations) was simulated; a weather file with continuous rain ( 0.4 inches or $10 \mathrm{~mm} /$ hour) was used. Note that exterior conditions might be only at $100 \% \mathrm{RH}$, without bulk water/wet conditions; cases without bulk water would have lower moisture transmission rates. A constant exterior temperature of $59^{\circ} \mathrm{F} / 15^{\circ} \mathrm{F}$ was selected. Actual conditions would vary sinusoidally, but constant levels were a simplification for this work. Interior conditions were either maintained at a constant level $\left(68^{\circ} \mathrm{F} / 20^{\circ} \mathrm{C} / 50 \% \mathrm{RH}\right)$, or varied sinusoidally over the course of a year. 
No simulations were run with a separate vapor-impermeable drainage layer (such as self-adhered membrane, air gap membrane, or polyethylene). All of those materials will reduce vapor transmission to almost zero (if correctly installed), so were not considered worth simulating.

A typical insulated assembly is shown below in Figure 38, which shows the insulated case. Two inches $(51 \mathrm{~mm})$ of closed cell polyurethane spray foam was applied directly to the interior face of the foundation.

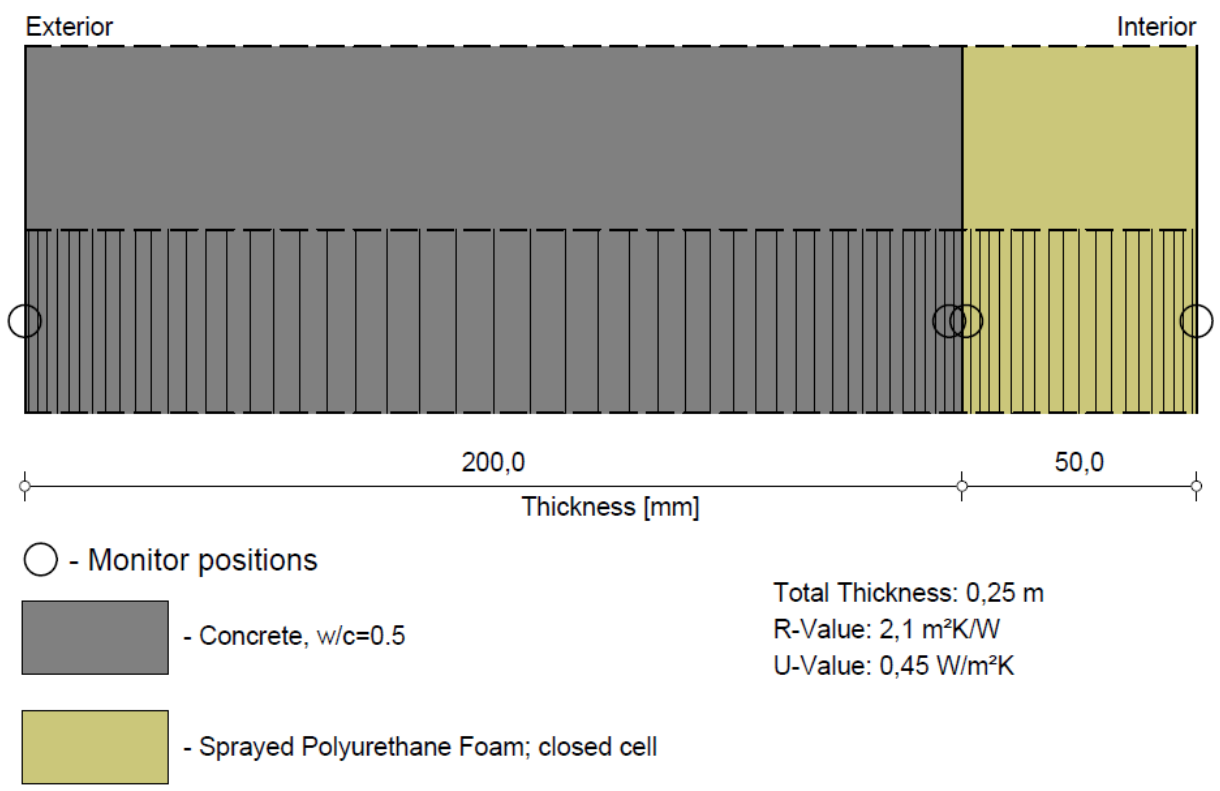

Figure 38. WUFI insulated model setup, showing layers and monitor positions

Simulations were run over seven simulated years, to allow for development of steady-state conditions.

\subsection{Results and Conclusions}

The first result of interest was the amount of moisture flow (flux) through the wall assembly. The results are shown in Figure 39, expressed in normalized terms of $\mathrm{kg} / \mathrm{m}^{2} \cdot$ year. It is clear that adding interior ccSPF insulation results in a substantial drop in moisture flow, by roughly a factor of 10. This is the result of both greater vapor resistance to the interior (through the foam), as well as the reduced surface temperature of the foundation wall (resulting in less energy for evaporation of moisture into the space). There are slight differences between maintaining the interior at steady-state vs. variable conditions, but it is a small effect relative to insulated/uninsulated conditions.

These rates can be used to estimate the rate of moisture supply to a house through uninsulated and insulated concrete basement walls (not counting the slab). We assumed a 30 by 40 foot (9.1 $\mathrm{m} \times 12.2 \mathrm{~m}$ ) basement with 8-foot $(2.4 \mathrm{~m})$ high walls, and used the two calculated rates for the entire height of the wall (an overestimate). The calculated rates are $\sim 2.8$ liters/day for the uninsulated cases, and 0.3 liters/day for insulated cases. These rates can be compared to moisture production rates of the occupancy/activities of a family of four, at 10-15 liters/day, or that of a person (body evaporation only), at 0.75 (sedentary) to 1.2 (average) liters/day (Straube and 
Burnett 2005). Therefore, the moisture emissions from a foundation insulated with ccSPF are minor contributions.

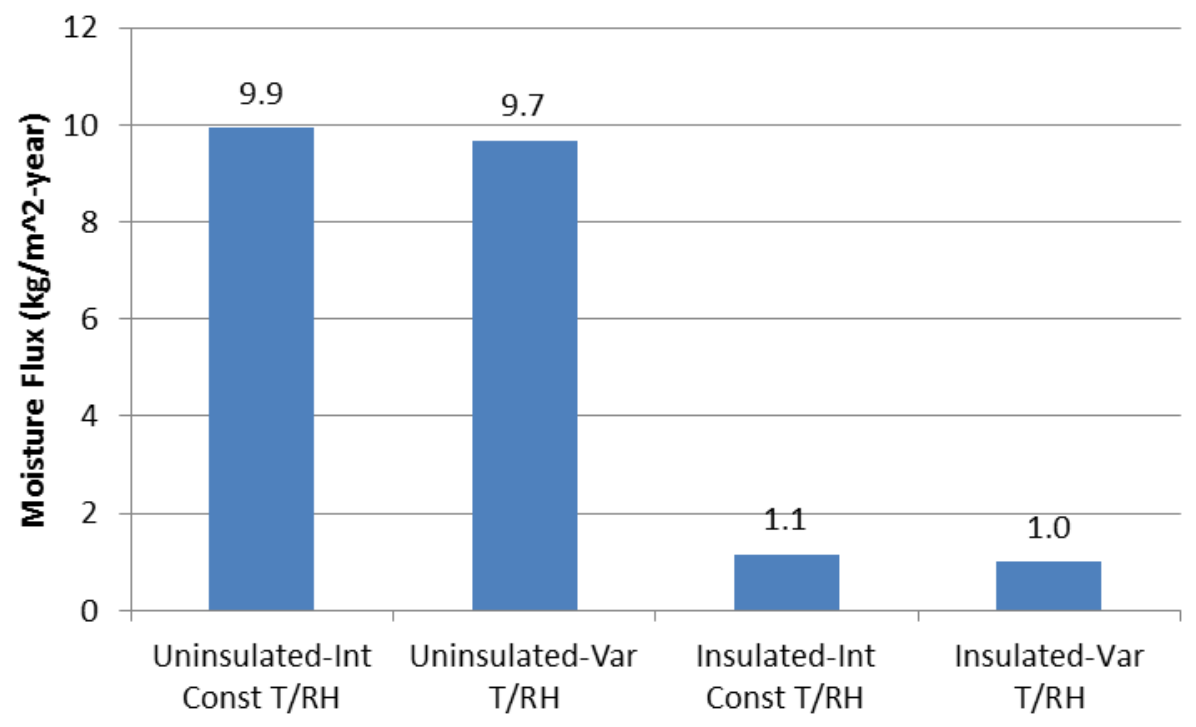

Figure 39. Moisture flux through concrete (and insulation), $\mathrm{kg} / \mathrm{m}^{2} \cdot \mathrm{year}$

In addition, the conditions of the concrete wall can be compared, before and after this retrofit. The water contents of the concrete layer $\left(\right.$ in $\mathrm{kg} / \mathrm{m}^{3}$ ) are plotted below in Figure 40.

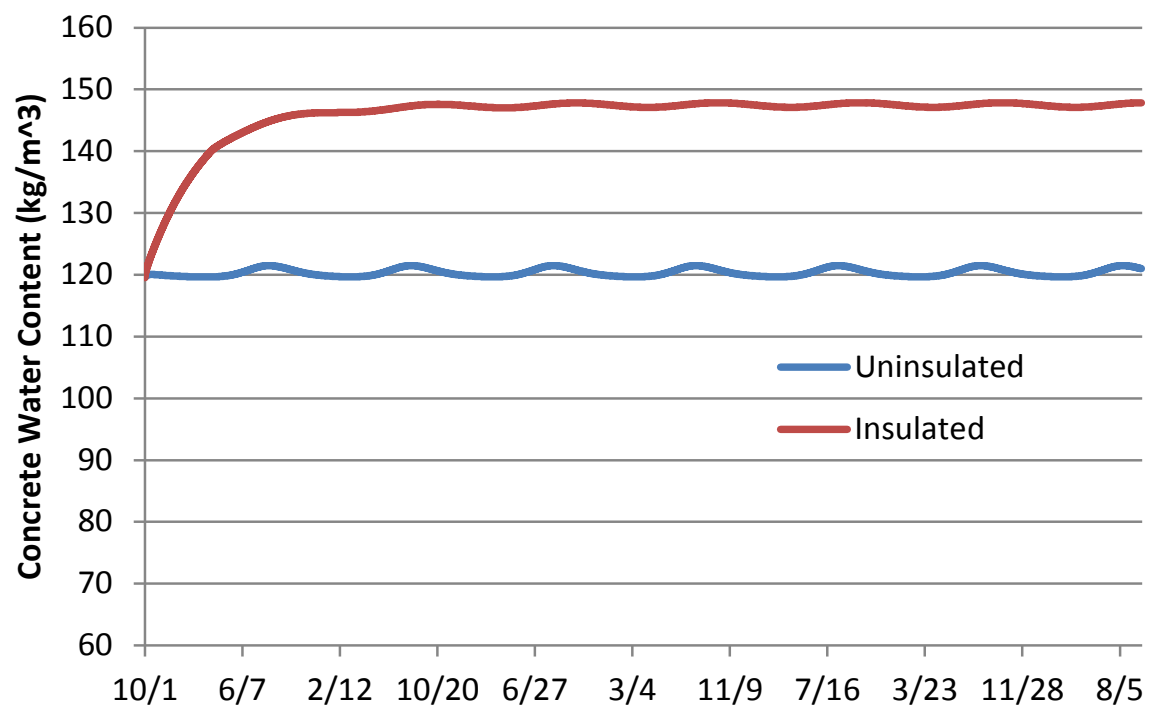

Figure 40. Concrete layer moisture content, $\mathrm{kg} / \mathrm{m}^{3}$, pre- and post-insulation

Insulation of the foundation wall results in wetter conditions, as shown by the rise in moisture content from $\sim 120$ to $150 \mathrm{~kg} / \mathrm{m}^{3}$ (7.5 to 9.4 pounds/cubic foot). Simulations also show that the conditions at the foundation-insulation interface remain close to $100 \% \mathrm{RH}$. Note that the freezethaw issues covered in above-grade masonry retrofits are a much smaller concern here, as foundation wall temperatures are tempered by ground contact. 
Overall, it is important to remember that these simulation results are based on a one-dimensional section of the assembly, and does not account for two-dimensional effects, any bulk water leakage (including gravity drainage and/or concentration) or air leakage effects. It also has an underlying assumption of the presence of bulk water against the exterior side of the wall; drier basements will have lower moisture flux levels. However, it is still reasonable to conclude that the installation of closed cell foam significantly reduces moisture flux into the basement, which aligns with field experience.

One potential damage function of masonry walls is erosion of mortar and spalling of brick surfaces due to capillary rise through the masonry wall, as discussed by Lstiburek (2007), and shown by the excerpt in Figure 41. This is due to transport of dissolved salts in the water passing through the assembly: the salts are deposited where the moisture evaporates. Insulating the wall reduces moisture emission through the wall, which should result in a greatly reduced (by a factor of $\sim 10$ ) rate of capillary erosion of the foundation components. However, further research is warranted to ensure that there are no unintended consequences in this retrofit.
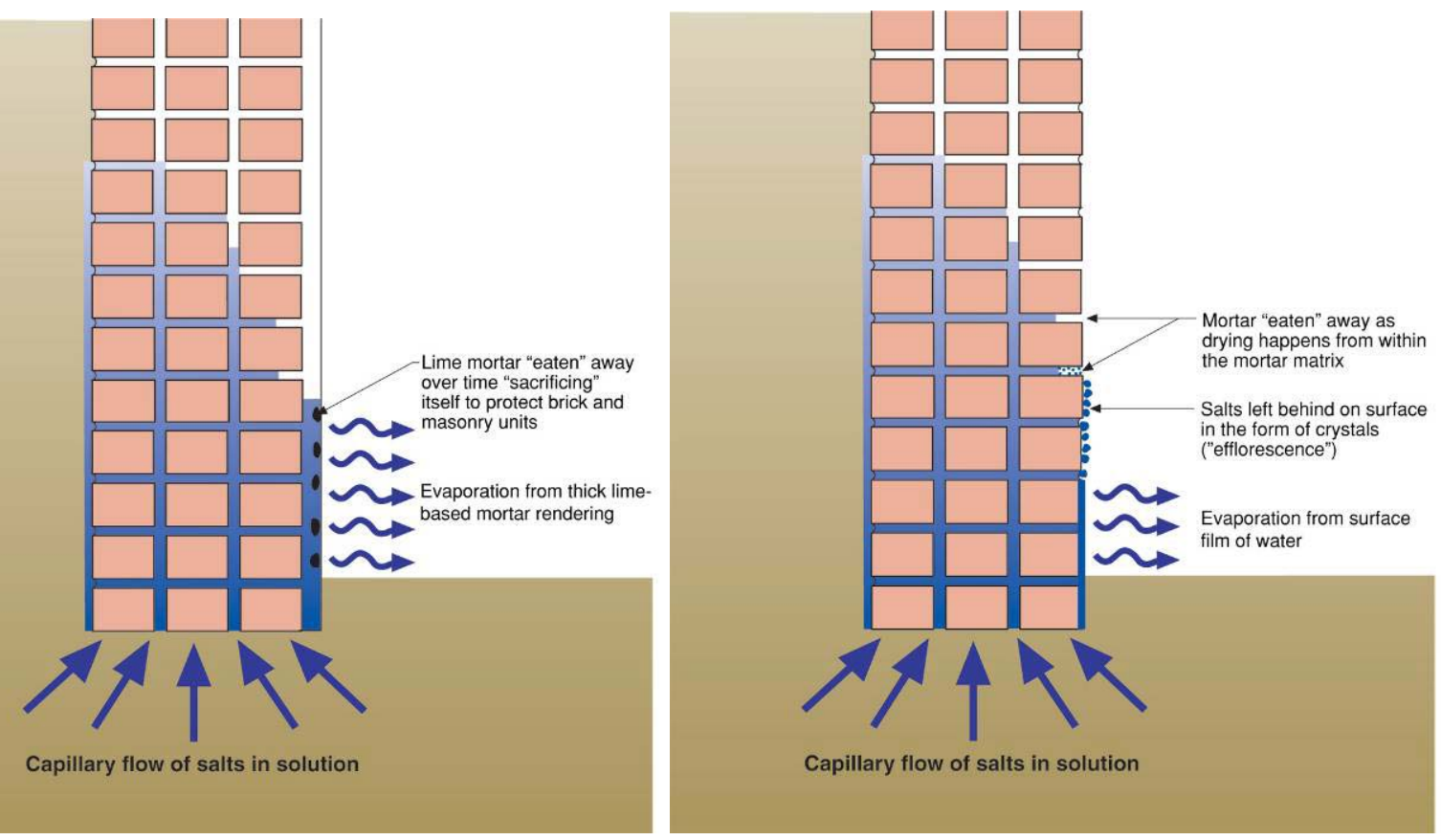

Figure 41. Parging and mortar erosion due to capillarity (Lstiburek 2007) 


\subsection{Critical Takeaways}

Interior insulation of foundation walls with closed cell spray foam (assuming damp conditions/capillarity) result in a tenfold reduction in moisture movement through the foundation. This means that the moisture/humidity contribution of the foundation drops to negligible levels.

The foundation wall will operate at colder temperatures and conditions of greater dampness (higher moisture content). However, freeze-thaw concerns are unlikely, as foundation wall temperatures are tempered by ground contact.

Interior insulation with ccSPF will reduce the rate of efflorescence, due to reducing the rate of evaporation of moisture through the foundation wall assembly. 


\section{Sill Beam/Rim Joist Durability Issues}

In these basement/crawl space closed cell spray foam retrofits, the use of spray foam at the sill beam/rim joist provides several energy conservation and durability benefits. The spray foam provides excellent air barrier continuity: the rim joist area contributes a great deal of air leakage due to its many components, and connections between the above grade wall and foundation wall. In addition, it is an air-impermeable material, so it prevents interstitial condensation at this location.

However, there are durability concerns from this interior insulation technique: the beam is colder (and therefore wetter) than its pre-retrofit condition. Energy and airflow are not available to assist in drying. In addition, the use of low-permeability ccSPF on the interior greatly reduces drying to the interior.

It must be noted that rot damage is often seen in existing historic sill beams, such as the "Westford Barn/House" and "Bedford Farmhouse Retrofit" projects. This damage can be hidden in the structure (see Figure 42), only becoming apparent during disassembly and the "sill lift" procedure for addition of the capillary break. This should provide some caution to those who assume that because a historic building is still standing, that it is not suffering from this type of hidden moisture damage. This damage, if left untreated (assuming the moisture source is still there), would become even worse after an interior insulation retrofit.
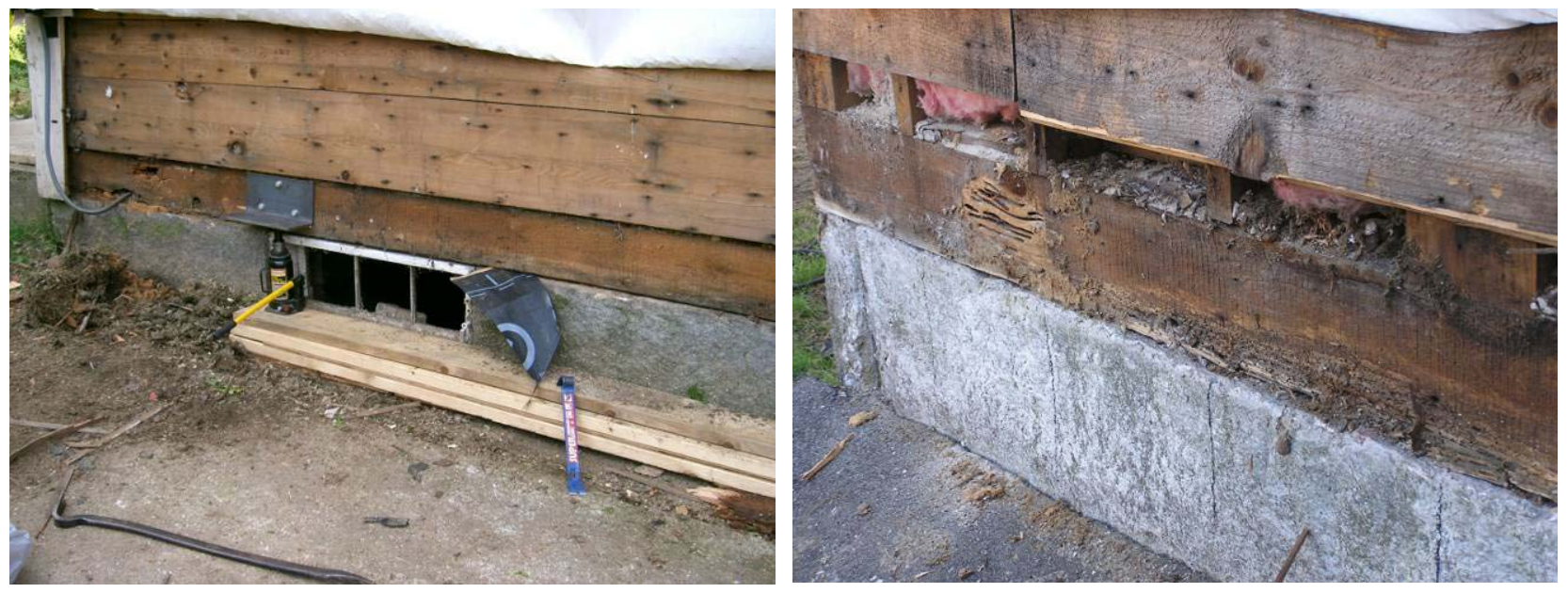

Figure 42. Sill lift and pre-retrofit sill beam condition at Bedford Farmhouse

The pattern of damage is shown below in Figure 43, and the worst damage is typically seen on the underside of the sill beam. Rainwater concentrations (e.g., disconnected downspouts) that saturate the exterior wall are particularly linked to damage at the sill beam.

These factors are the reasoning behind the recommendation to retrofit a capillary break at the sill, as shown in Figure 19, thus limiting wetting from below. Simultaneously, wetting from the exterior should be controlled (i.e., retrofit of exterior drainage planes and back-ventilated claddings, or at minimum a back-ventilated "water table" trim detail). 

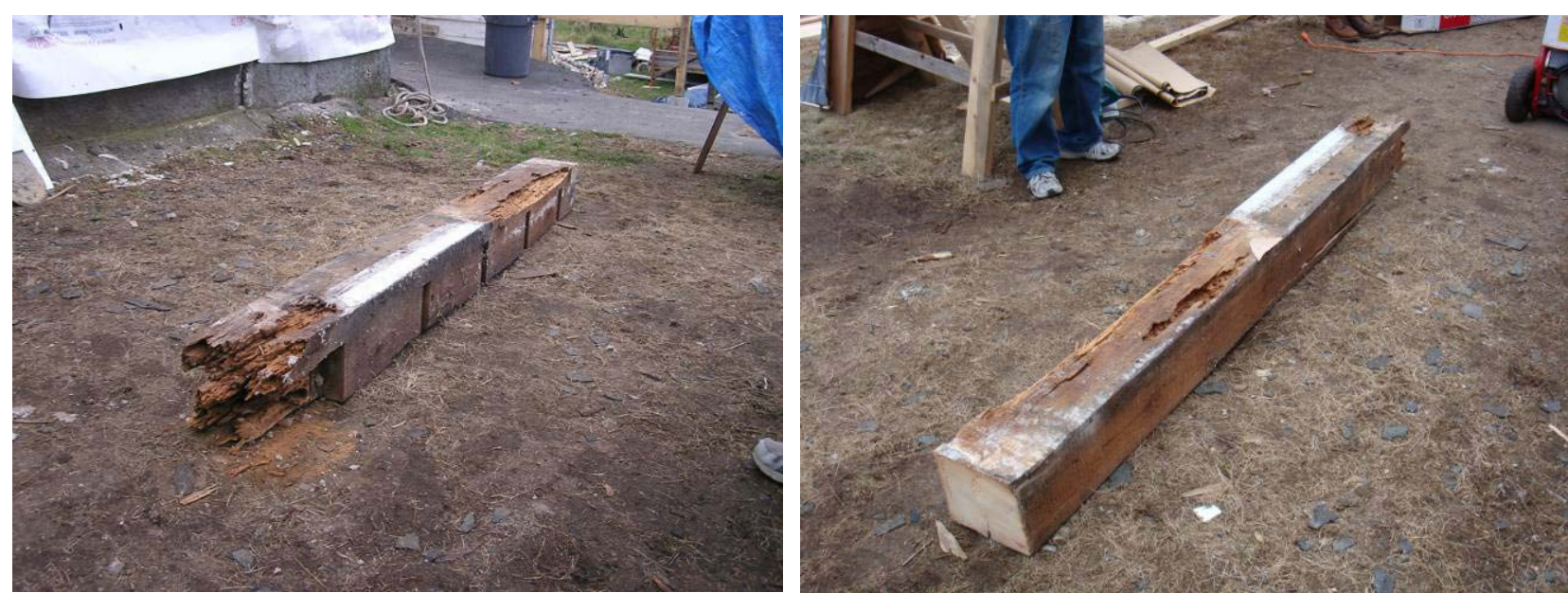

Figure 43. Damaged sill beams from Bedford Farmhouse

The geometry of the retrofitted "Bedford Farmhouse" project is shown in Figure 44; the project was a deep energy retrofit of an existing building, and included exterior insulation of the existing above-grade walls.

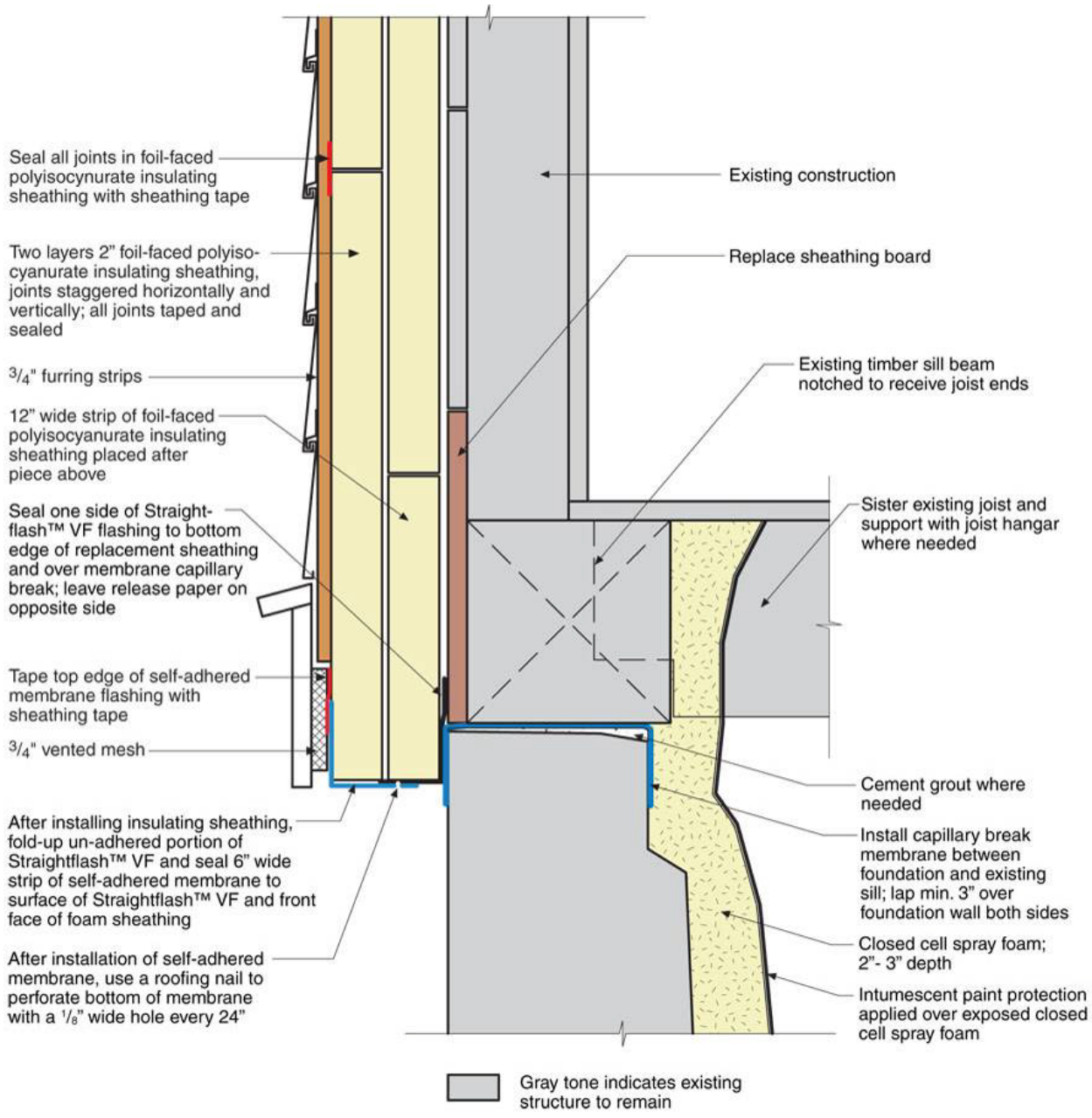

Figure 44. Sill beam detail at Bedford Farmhouse deep energy retrofit project 
Note that this "sill lift" procedure is most amenable to wood-frame structures with lightweight claddings; claddings such as stucco or brick would be more difficult to work with. Furthermore, stucco and brick are reservoir claddings, which can act as an exterior moisture source, resulting in potential durability issues when combined with an interior closed cell spray foam retrofit. Therefore, these situations should be approached with caution.

The combined effect of these two measures (exterior insulation of above grade wall vs. interior insulation of foundation wall) was studied in more detail. Heat flow simulations were run using THERM 5.2 (LBNL 2003) Two-Dimensional Building Heat-Transfer Modeling Software. Note that this is a steady-state software package, so it does not capture dynamic effects, thermal mass, or any solar gain effects. Boundary conditions were as follows:

Table 4. Boundary Conditions for Foundation THERM Simulations

\begin{tabular}{cc}
\hline Boundary condition & Measurement \\
\hline Exterior air temperature & $8^{\circ} \mathrm{F}$ (Boston $99.6 \%$ design temperature) \\
\hline Interior (above grade space) air temperature & $70^{\circ} \mathrm{F}$ \\
Basement air temperature (pre-retrofit) & $50^{\circ} \mathrm{F}$ \\
Basement air temperature (post-retrofit) & $60^{\circ} \mathrm{F}$ \\
Soil temperature & gradient with height, from $30^{\circ} \mathrm{F}$ to $45^{\circ} \mathrm{F}$ \\
\hline
\end{tabular}

Color-coded temperature images of these simulation results are shown in Figure 45.
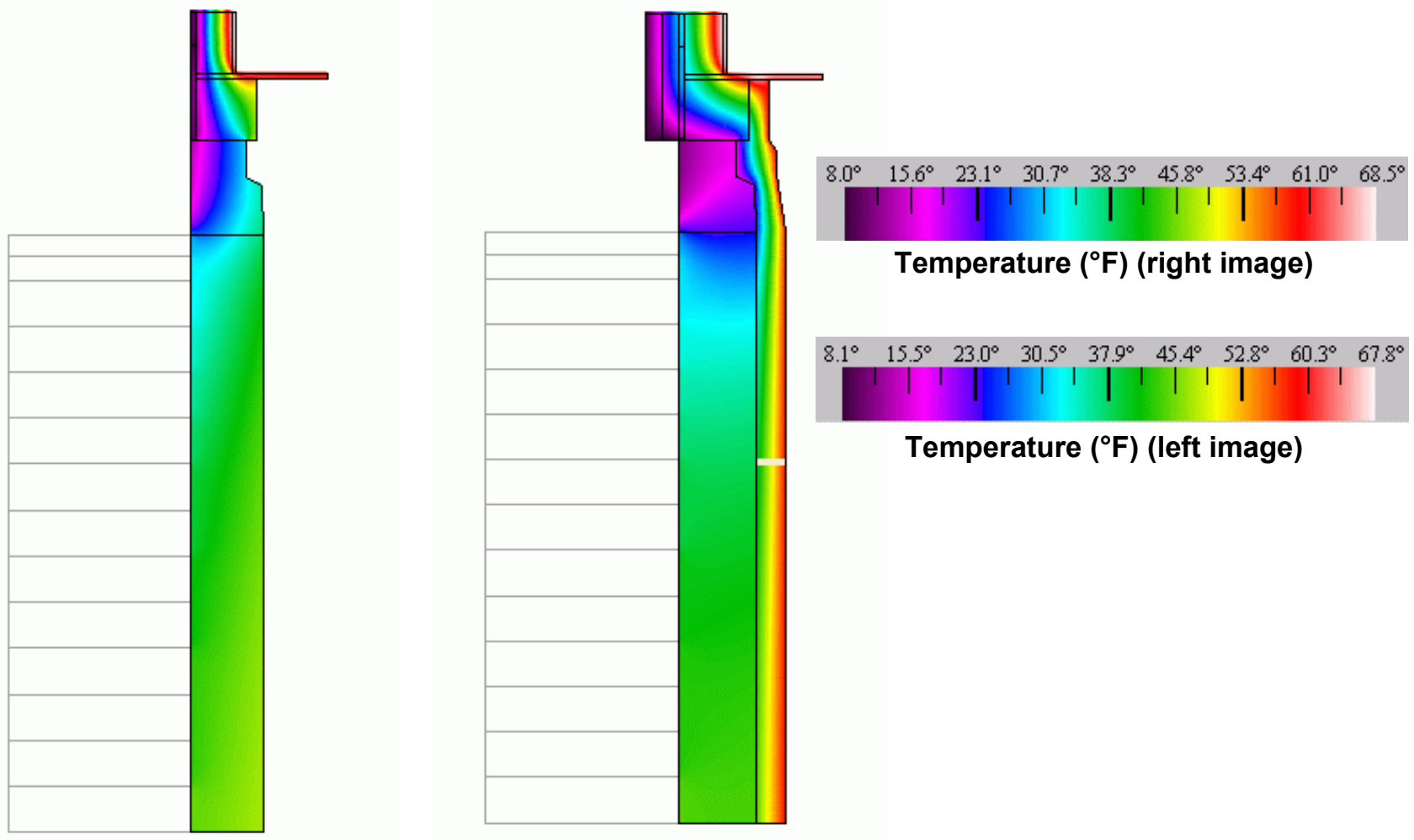

Figure 45. Pre- and post-retrofit basement wall and sill beam temperatures 
The bottom of the sill beam is clearly colder in its insulated state, compared to the pre-retrofit case, even with the "protection" of the exterior above grade wall insulation. This is due to thermal bridging through the exposed portion of the foundation wall. Note that cold temperatures penetrate along the entire bottom surface of the sill beam after the retrofit.

Overall, it is worthwhile to list the various risk factors for damage to the sill beam in the postretrofit condition. Each factor described below can either increase or decrease the risk of moisture damage at the beam:

Exterior water control features. Poor flashings, reverse laps, and water concentration details (e.g., disconnected downspouts) can all provide moisture loadings far greater than the other risk factors listed below. Proper water control is critical to achieve success with this interior insulation detail.

Capillary activity of foundation: This determines the amount of "wicking" that occurs from the surrounding soil, or "splashback" water, into the beam. Softer stones (e.g., sandstone) have high liquid water uptake values $\left(\mathrm{A}_{\mathrm{w}}\right)$, as does brick. Concrete has lower $\mathrm{A}_{\mathrm{w}}$ values, and hard stones (e.g., granite) have extremely low values. However, it is important to remember that mortar joints are also at play, and that foundations with an exterior granite facing may have brick or concrete backup walls.

Magnitude of splashback: Splashback will be a function of roof runoff volume, roof height, and permeability or "hardness" of the adjacent ground.

Height of sill beam/rim joist above grade: This directly influences the two previous items; sill beams that are closer to grade are at higher risk.

Drainage plane location: In many of these retrofit projects, exterior insulation is used, which shifts the drainage plane further off the foundation wall. This results in water being kept away from the face of the foundation, and some degree of "sheltering" of the foundation, thus reducing risk.

Permeability of exterior: In some exterior insulation retrofit installations, a vapor permeable insulation material has been used at the sill beam, such as expanded polystyrene (EPS), mineral fiber or high-density fiberglass (Figure 46). This would tend to mitigate risk by allowing greater drying to the exterior. For instance, 2 " of EPS is roughly 2 perms $\left(114 \mathrm{ng} /\left(\mathrm{Pa} \bullet \mathrm{s}^{\bullet} \mathrm{m}^{2}\right)\right.$, and 2 " of mineral fiber is roughly 48 perms $\left(2740 \mathrm{ng} /\left(\mathrm{Pa} \bullet \mathrm{s} \bullet \mathrm{m}^{2}\right)\right.$ (both measurements dry cup).

This issue is a matter of further study. For instance, there is a limited survey of sill beam moisture contents in retrofitted basements; as discussed in Section 7 "Field Survey Work." However, further study is needed to better understand the contribution of these various loading factors, and the relative effectiveness of various mitigation techniques. 

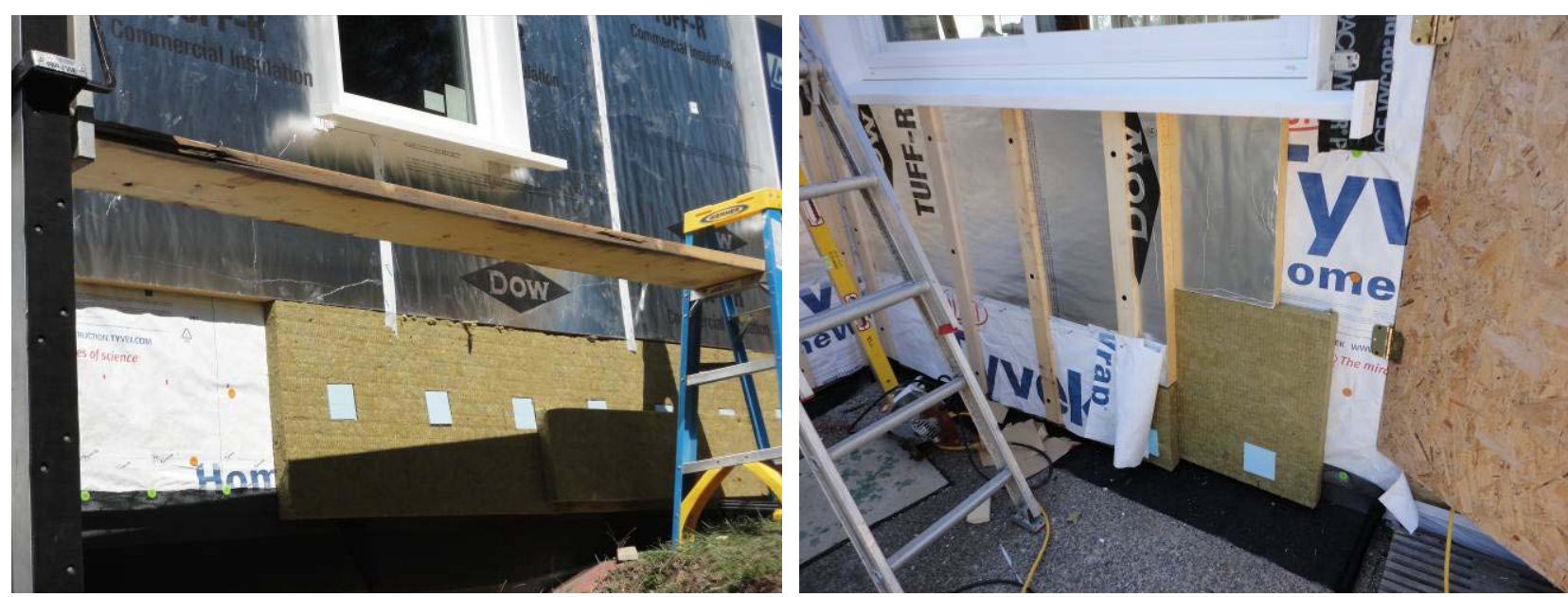

Figure 46. Sill beam insulated with vapor-permeable mineral fiber insulation overclad

In addition, the Westford Barn/House project was stripped and reclad in 2011, after original construction circa 1996-2000 (Lstiburek 2011). The sill beam was protected by a capillary break (self-adhered membrane) on top of the foundation. Interior spray foam was applied, and the exterior of wall included 6 mil polyethylene (air barrier), 6"/152 mm thick EPS insulation, and a drained and ventilated rainscreen cladding. Note that the sill beam was essentially wrapped in vapor impermeable materials. However, during disassembly, the sill beam's condition was pristine, with no sign of damage at all, despite lack of drying of this assembly. This design carefully controls the wetting to the sill beam, which is the key to its durability.
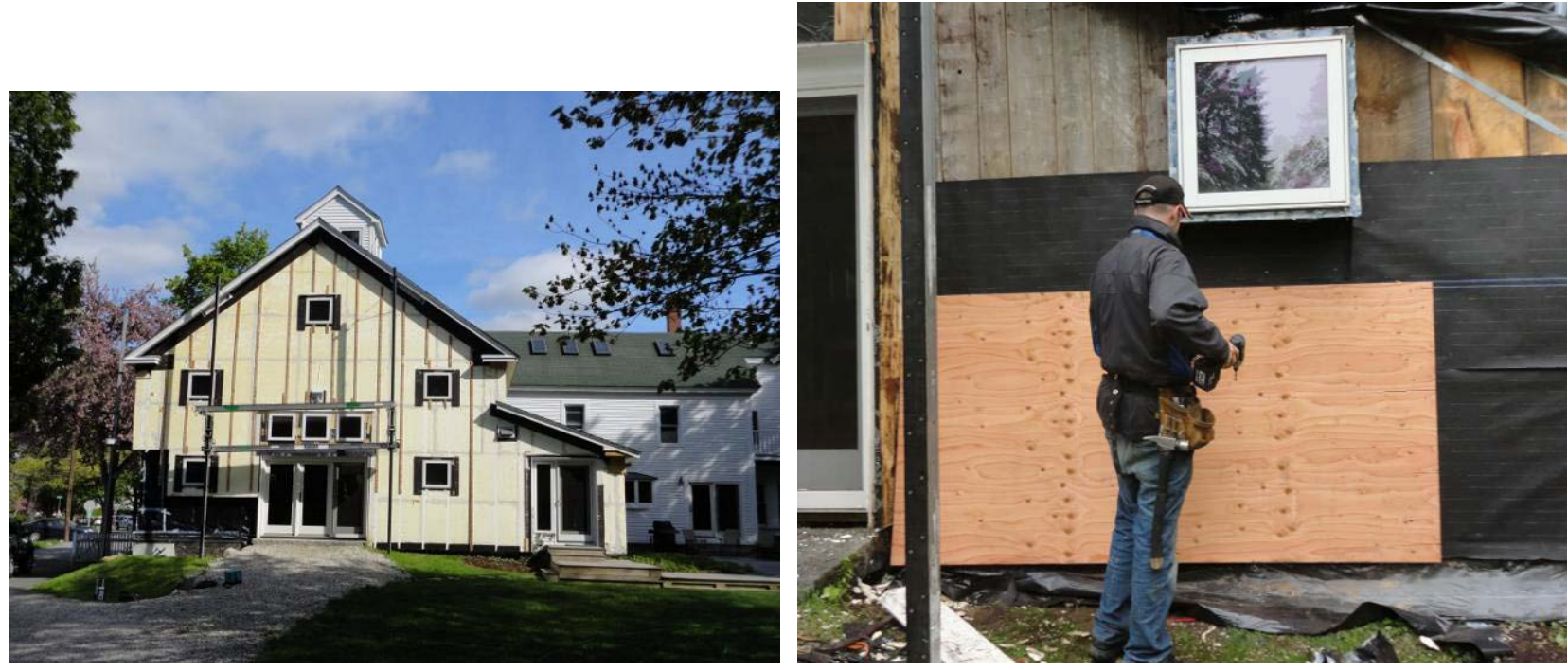

Figure 47. Westford House/Barn recladding and sill beam inspection

\subsection{Critical Takeaways}

Interior spray foam retrofits at the sill beam result in less energy flow (heat and air), resulting in greater risk of moisture damage.

There could be existing hidden damage at sill beams; thorough inspection before insulating is recommended. 
The retrofit installation of a sill capillary break is recommended to control wetting from below.

Wetting from the exterior should be controlled (i.e., retrofit of exterior drainage planes and backventilated claddings, or at minimum a back-ventilated "water table" trim detail).

There are various interacting risk factors at play: further study is recommended to better understand their relative contributions, and the effectiveness of various mitigation techniques. 


\section{Field Survey Work}

\subsection{Overview}

Access was available for four sites insulated with these types of interior basement insulation systems; they have been in operation from two to fifteen years. Site visits were scheduled for all of these locations, to examine them in detail, determine how they were performing, and inspect for any sign of long term damage. This survey was completed in early July 2011.

\subsection{Survey Approach and Measurements}

All four sites are located in Boston area (DOE Zone 5A); these projects were completed from 1996 through 2009. The energy retrofits and renovations of the Westford House/Barn, Somerville Office, and Concord House were all discussed in Pettit (2008). The Bedford Farmhouse was covered in previous Building America work (2009: "Habitat for Humanity of Greater Lowell, Farmhouse Renovation, Bedford, MA"). All of these projects have rubble stone or brick foundation walls. There are a variety of interior water control measures, which were chosen based on the historical bulk water leakage risk. For instance, the "Westford House/Barn" consistently had water leakage during rain events, so a full height self-adhered membrane draining to an interior perimeter drain was installed. In contrast, the "Somerville Office" had ccSPF applied directly to the foundation walls, with no interior drainage system.

Table 5. List of Survey Sites

\begin{tabular}{cccc}
\hline \multicolumn{1}{c}{ Site } & Location & $\begin{array}{c}\text { Installation } \\
\text { year }\end{array}$ & Drainage Material/Details \\
\hline Westford House/Barn & Westford, MA & 1996 & $\begin{array}{c}\text { Self-adhered membrane } \\
\text { (full height) }\end{array}$ \\
Comerville Office & Somerville, MA & 2003 & $\begin{array}{c}\text { None (spray foam } \\
\text { on foundation wall) }\end{array}$ \\
Bedford Farmhouse & Concord, MA & 2006 & $\begin{array}{c}\text { Mesh drainage mat } \\
\text { (partial height up wall; see Figure } \\
\text { 28 and Figure 29) }\end{array}$ \\
\hline
\end{tabular}

Measurements and observations taken at the sites included the following. Note that not all measurements were done at all sites due to access restrictions (these items are noted in the text). The instrumentation used to make these measurements is shown in Table 6.

- Temperature and relative humidity of the basement space: Note that this is a "snapshot" in time, and not necessarily representative of year-round performance. However, it provides some indication of the moisture conditions within the space.

- Temperature and relative humidity of the above-grade space: Taken at some sites as a comparison point. 
- Temperature and relative humidity behind spray foam installation (insulation-foundation wall interface): When a drainage layer was present (e.g., Westford House/Barn), this measurement was taken at the airspace between the self-adhered membrane and the foundation wall.

- Surface temperatures: This included infrared thermography of the interior of the basement, examining temperatures of the exposed slab, ccSPF interior surface, and thermal anomalies at service penetrations. In addition, where a sump pit was available, the temperature was measured to estimate ground temperature beneath the insulated slab.

- Removal of a section of insulation, to examine the condition of the ccSPF, and conditions behind the insulation: In addition, the surface temperature of the foundation wall was taken with infrared thermography.

- Measurement of sill beam moisture content (from the interior side): This measurement was only available at Bedford, Westford, and Somerville.

Table 6. Instrumentation for Field Survey

\begin{tabular}{cc}
\hline Measurement & Instrument \\
\hline Temperature and relative humidity & Vaisala HMI41/HMP42 \\
Wood moisture content & Delmhorst BD-10 \\
Surface temperatures & FLIR b40 Infrared Camera \\
\hline
\end{tabular}

\subsection{Survey Results}

The survey results included the following observations. The most critical points are summarized in the "Critical Takeaways" section.

\subsubsection{Temperature/Relative Humidity Conditions}

The temperature and humidity conditions at the spray foam/foundation wall interface were measured by drilling a test hole, and inserting the T/RH probe with a tapered gasket (Figure 48).
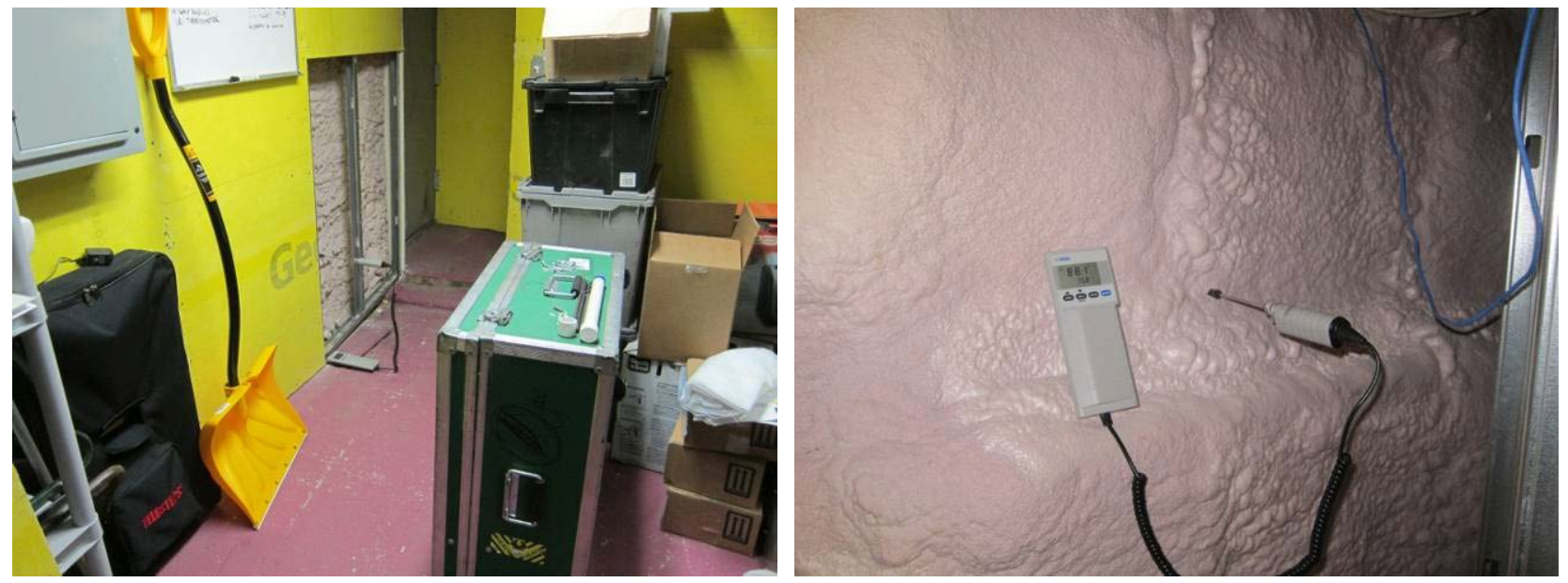

Figure 48. Measurement of T/RH conditions behind ccSPF insulation, Somerville Office 
The basement air T/RH and insulation/foundation interface conditions are plotted below for the four sites, as shown on the color coded plot. Interior conditions were within the expected range: at the low end of typical interior setpoints (no or minimal glazing in basements, thus low solar gains), and dewpoints between $55-60^{\circ} \mathrm{F}\left(13-16^{\circ} \mathrm{C}\right)$. All test sites had cooling systems in operation at the time of measurement. Note that exterior dewpoints were in the $60^{\circ}-65^{\circ} \mathrm{F}(16$ $18^{\circ} \mathrm{C}$ ) range during these measurements.

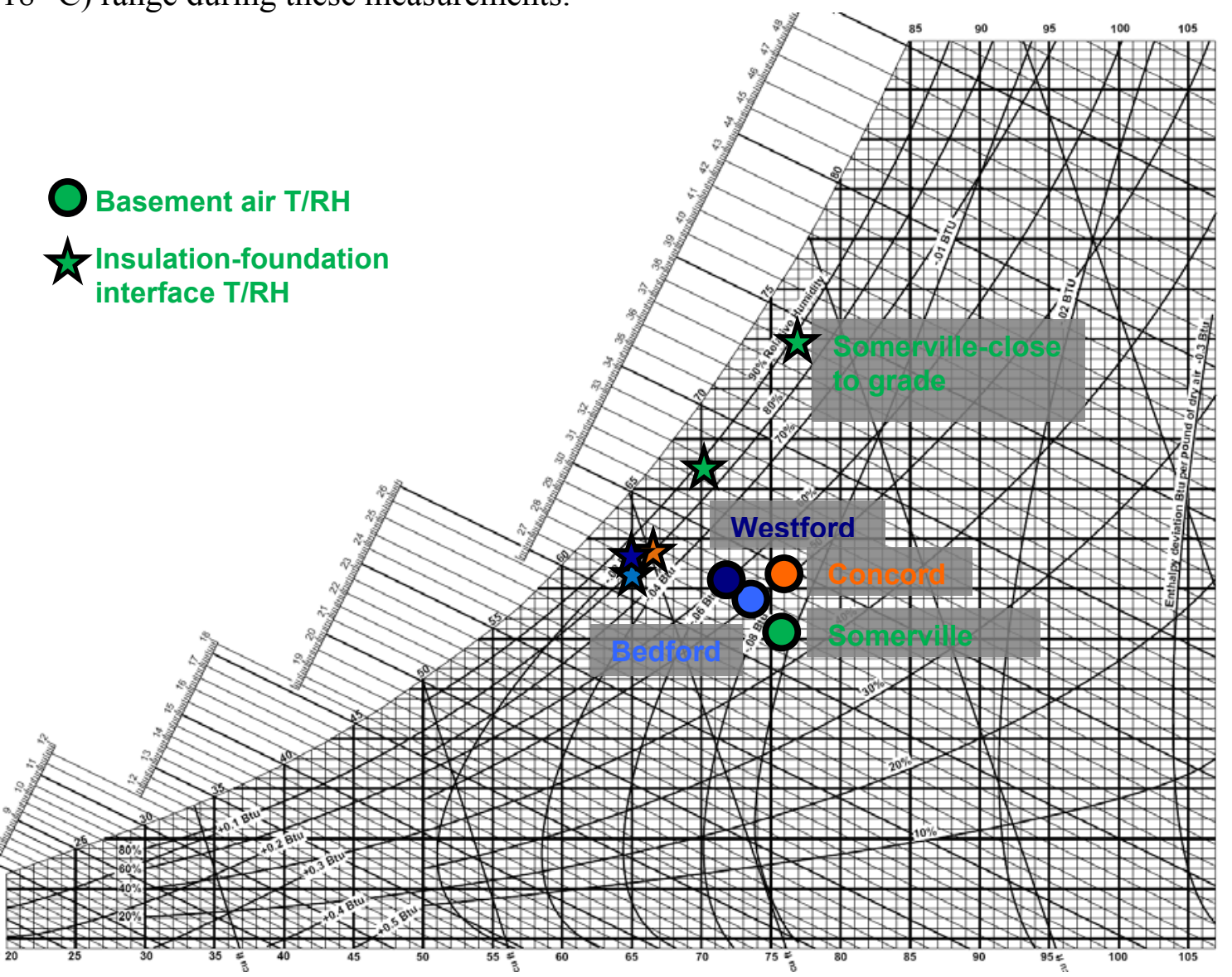

Figure 49. Psychrometric comparison of survey site conditions (basement and exterior to foam)

At the Westford site, the above grade space was at $79^{\circ} \mathrm{F} / 26^{\circ} \mathrm{C} / 45 \% \mathrm{RH}$, which is close to basement dewpoint conditions. Similar dewpoints were expected given the air communication between the spaces (transfer grilles; ductwork and air handler located in basement space).

The relative humidity conditions behind the insulation consistently ranged from $80 \%-90 \%{ }^{+}$; temperature conditions outboard of the insulation were cooler than interior, as would be expected (even in summertime). Note that most of the measurements were done on the lower portions of the wall, which would retain cool temperatures throughout the summer.

Overall, the high humidity levels show the importance of maintaining air barrier continuity between the interior/basement space, and the insulation cavity space. Sustained operation at high humidity conditions is conductive to mold growth and poor IAQ. Very high humidity levels were originally expected (95\%-100\%), given the reduced drying to the interior. However, the equilibrium relative humidity in that space would be a function of the wetting from the exterior, so conditions are likely to vary seasonally and/or matching groundwater rise patterns. 
It is also interesting to note that the dewpoint (absolute air moisture content) is only slightly higher than interior conditions. This is largely a function of the surface temperature at the insulation-foundation interface: conditions are cool, which even at saturation $(100 \% \mathrm{RH})$ would keep dewpoints relatively low. The upshot is that there is not a tremendous inward vapor drive coming from the foundation, into the conditioned space, due to the cool basement wall conditions. The exception was the measurement, which was close to grade (under 1' below grade): it was a similar relative humidity as previous measurements $(91 \%)$, but at a higher temperature $\left(76^{\circ} \mathrm{F} / 24^{\circ} \mathrm{C}\right)$, resulting in a greater inward moisture drive.

For reference, the monthly average temperature and dewpoint for the year preceding these measurements, and monthly total precipitation, is plotted in Figure 50 below.

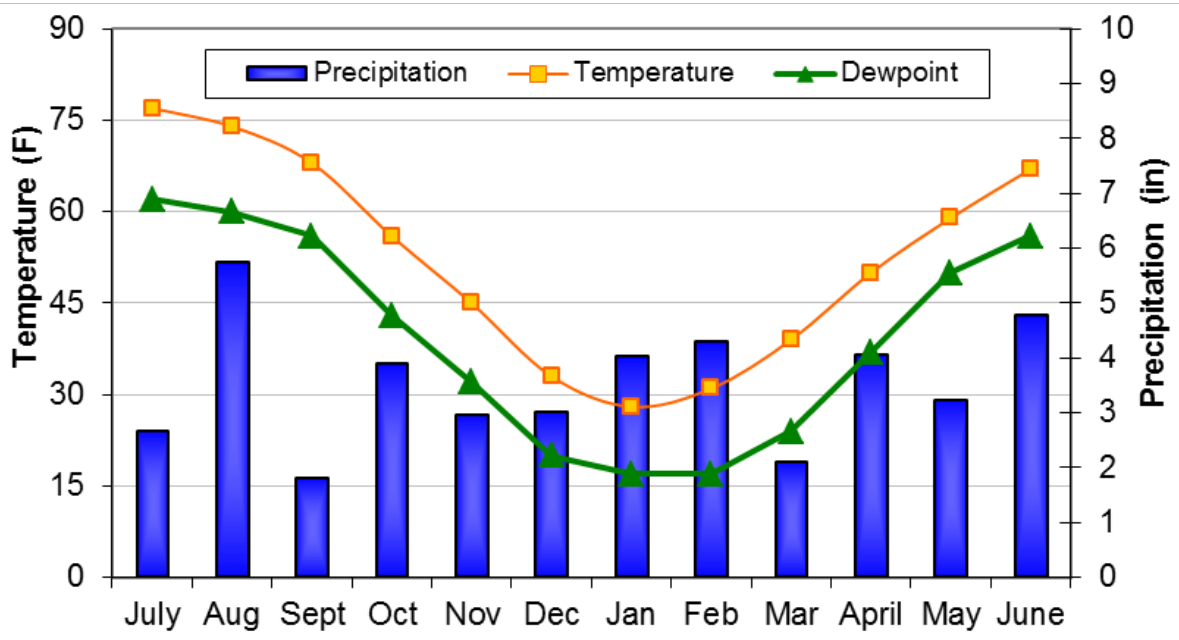

Figure 50. Boston area monthly temperature, dewpoint, and precipitation, 2010-2011

\subsubsection{Disassembly of Spray Foam}

Relatively small (under 6" x 6" or $150 \times 150 \mathrm{~mm}$ ) test ports were cut into all of the wall spray foam installations, to inspect the condition of the ccSPF and the foundation wall behind it. In general, it appeared that the foam was firmly and solidly bonded to the wall, except for the assembly with a deliberate airspace behind the foam (Westford Barn), which had some "give." The foam was sufficiently bonded to the substrate that it typically removed the surface grit or parging when the sample was removed (see Figure 52). The condition of the underlying masonry was good. There was no sign of freeze-thaw damage, or mortar erosion due to capillary moisture transport (albeit over a limited sampling area).

There was no apparent water uptake in the spray foam, based on appearance, texture, weight, and probing with the wood moisture content meter as a qualitative measurement (all measurements were below meter threshold). This was true in all cases where the spray foam was applied directly to the masonry wall, without a drainage layer behind it. 

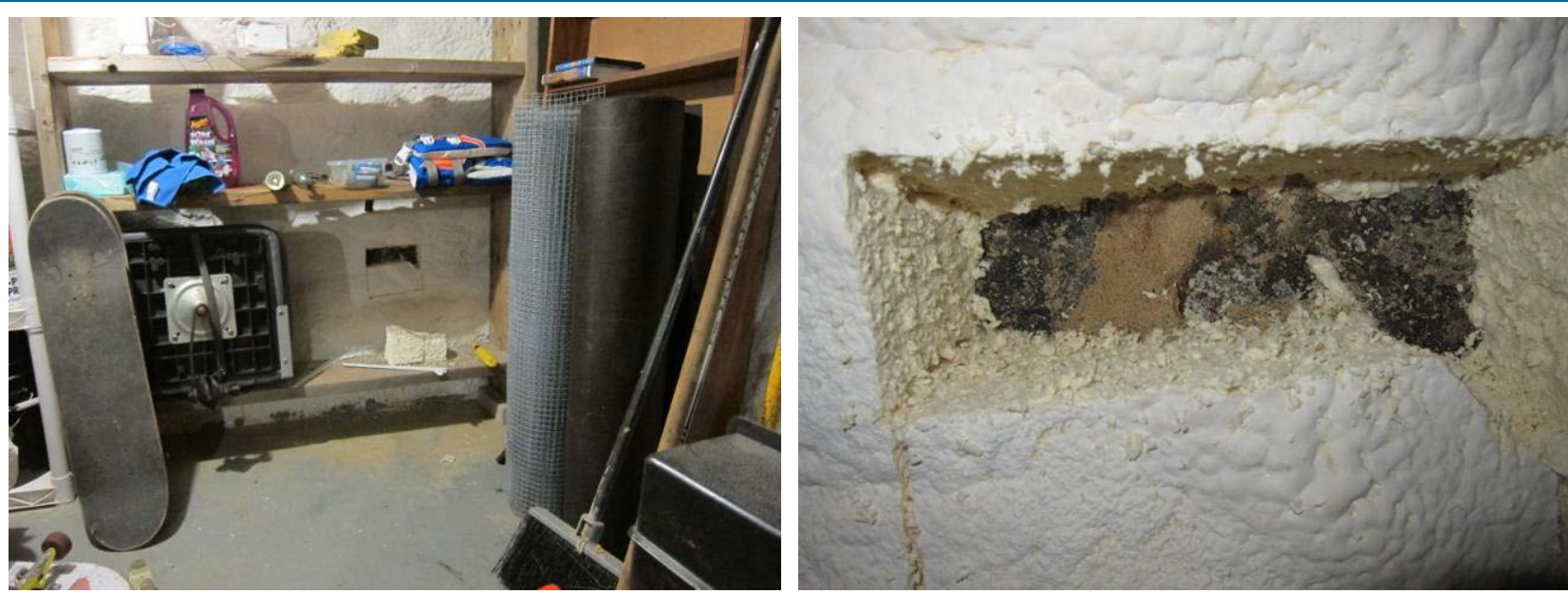

Figure 51. Test port cut into wall ccSPF, Bedford Farmhouse Renovation
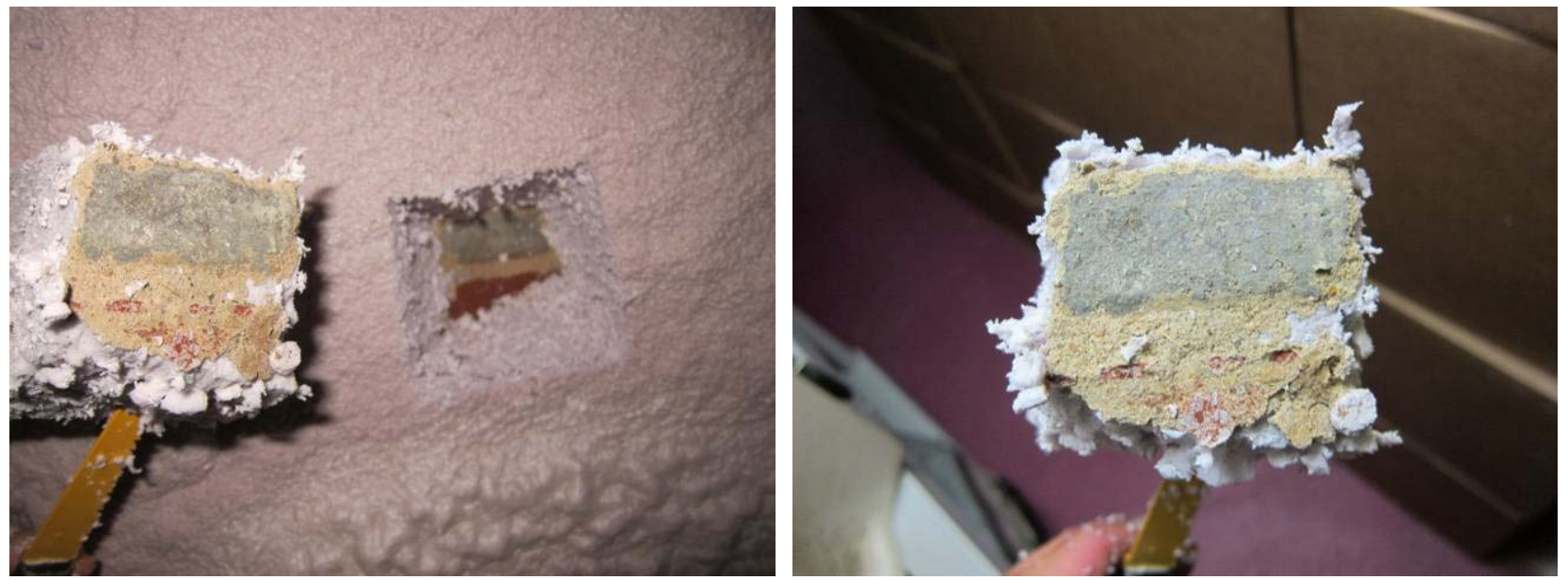

Figure 52. Test port cut into wall ccSPF, Somerville Office

The air space created by the self-adhered membrane in the Westford Barn/House was significant, ranging from 2-3"/50-75 $\mathrm{mm}$ deep (see Figure 53). Although there was some "give" to the foam when pressed by hand, this has no adverse effects on the function of the assembly.
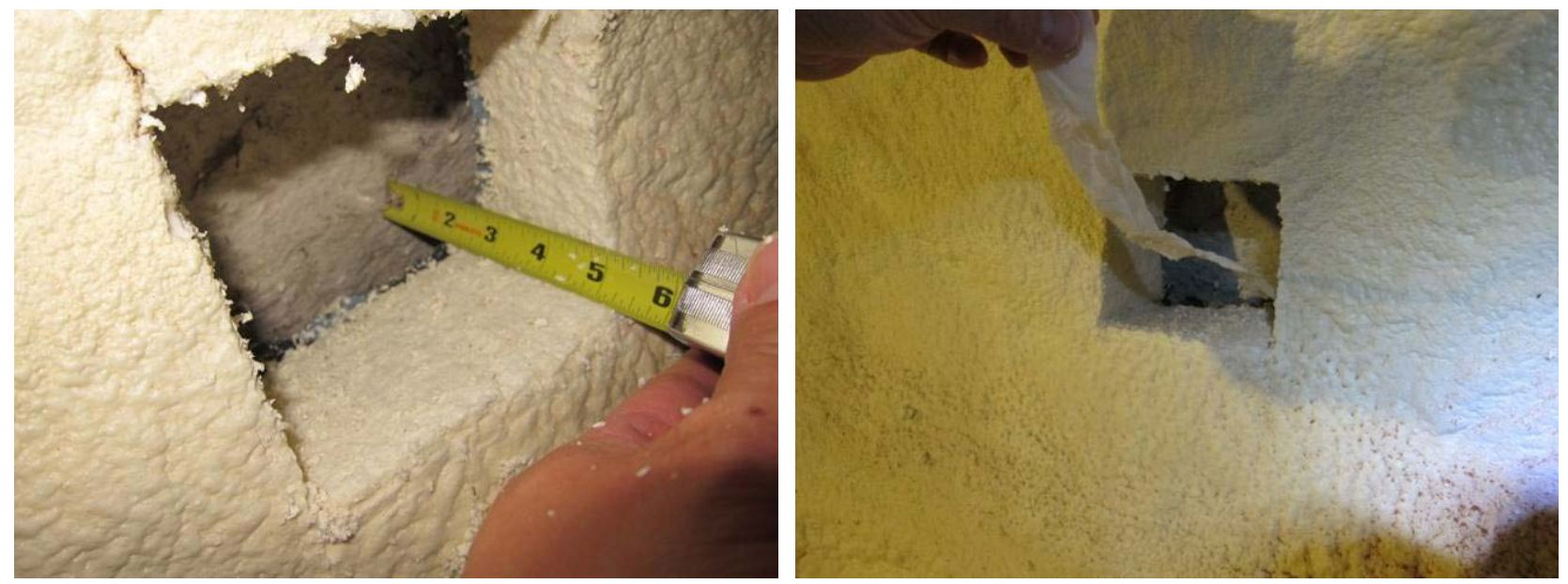

Figure 53. Air gap behind membrane; demonstration of airflow behind foam, Westford Barn/House 
When the test port was cut into the air space at a below-grade location, a noticeable amount of air movement occurred between the interior space and the airspace behind the foam (see Figure 53). This air movement (and pressure difference) was not mechanically induced; it was solely due to stack effect and/or possibly wind. This clearly demonstrates that that the rubble masonry wall does not act as an effective air barrier, and that some other control layer is required to provide this function. The air space behind the foam is connected to the exterior, via the tortuous paths through the masonry and the surrounding soil.

\subsubsection{Slab Surface Temperatures}

In all cases, the basement slabs were insulated with a minimum of R-10/RSI 1.8 XPS. Surface temperatures were quite even, typically several degrees cooler than basement air temperature. There were also some cooler locations, such as the perimeter of the slab (greatest heat loss), and thermal bridges such as the footings underneath columns. All infrared images shown in Figure 54 through Figure 58 were taken in summertime conditions, during the field survey (July 2011).

Table 7. Air Temperature/Relative Humidity, Slab, and Sump Pit Conditions

\begin{tabular}{cccc}
\hline & $\begin{array}{c}\text { Air } \\
\text { Temperature/Relative } \\
\text { Humidity }\end{array}$ & Slab Conditions & $\begin{array}{c}\text { Sump } \\
\text { Temperature }\end{array}$ \\
\hline Westford & $71^{\circ} \mathrm{F}\left(22^{\circ} \mathrm{C}\right)$ & $68-70^{\circ} \mathrm{F}\left(20-21^{\circ} \mathrm{C}\right)$ & $58-60^{\circ} \mathrm{F}$ \\
House/Barn & $60 \% \mathrm{RH}$ & $\left(68^{\circ} \mathrm{F} / 20^{\circ} \mathrm{C}\right.$ at thermal bridges $)$ & $\left(14-16^{\circ} \mathrm{C}\right)$ \\
Somerville & $75^{\circ} \mathrm{F}\left(24^{\circ} \mathrm{C}\right)$ & $73-75^{\circ} \mathrm{F}\left(23-24^{\circ} \mathrm{C}\right)$ & $\mathrm{n} / \mathrm{a}$ \\
Office & $45 \% \mathrm{RH}$ & & \\
Concord House & $78^{\circ} \mathrm{F}\left(26^{\circ} \mathrm{C}\right)$ & $72-75^{\circ} \mathrm{F}\left(22-24^{\circ} \mathrm{C}\right)$ & $60^{\circ} \mathrm{F}\left(16^{\circ} \mathrm{C}\right)$ \\
Bedford & $47 \% \mathrm{RH}^{\circ}$ & & \\
Farmhouse & $73^{\circ} \mathrm{F}\left(23^{\circ} \mathrm{C}\right)$ & $68-70^{\circ} \mathrm{F}\left(20-21^{\circ} \mathrm{C}\right)$ & $60^{\circ} \mathrm{F}\left(16^{\circ} \mathrm{C}\right)$ \\
\hline
\end{tabular}

The close match between slab temperature and air temperatures reveals that there is a minimal chance of slab condensation or high localized relative humidity issues.
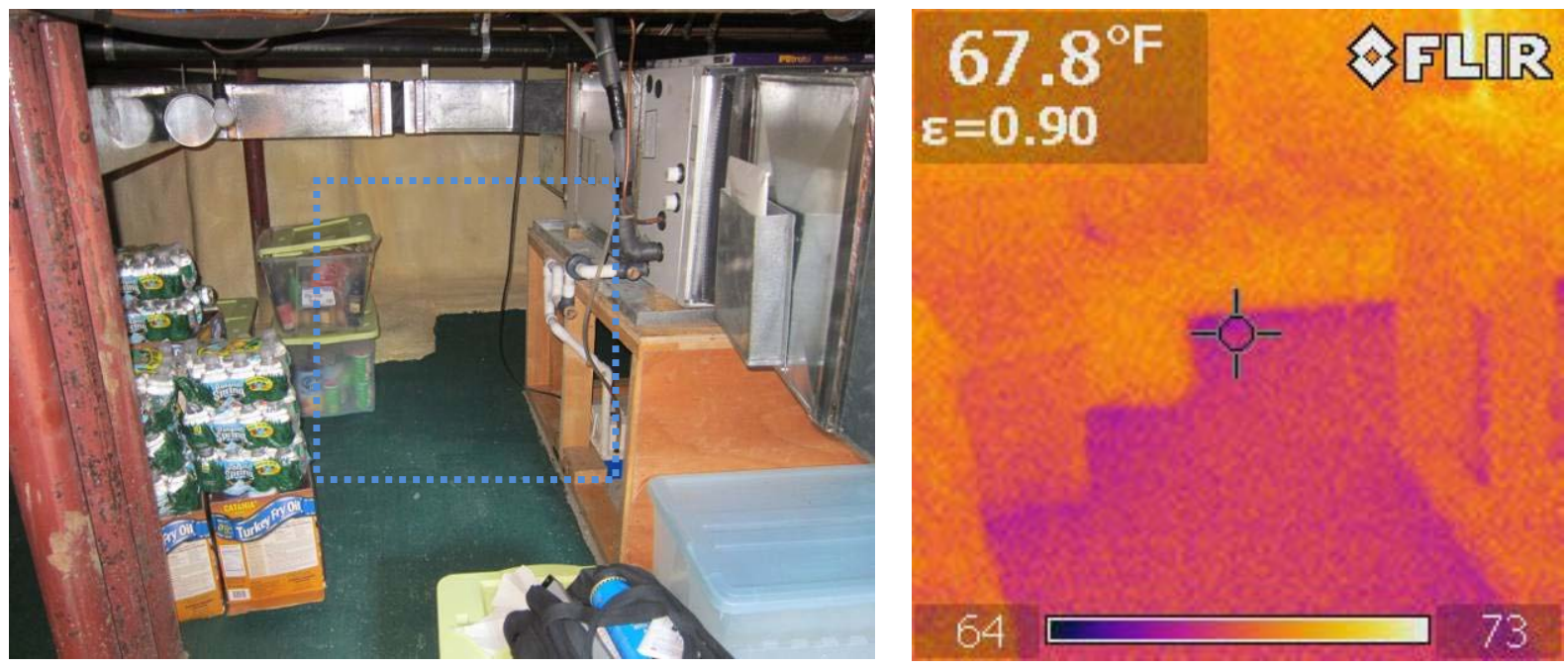

Figure 54. Slab temperature at perimeter, Westford Barn/House 

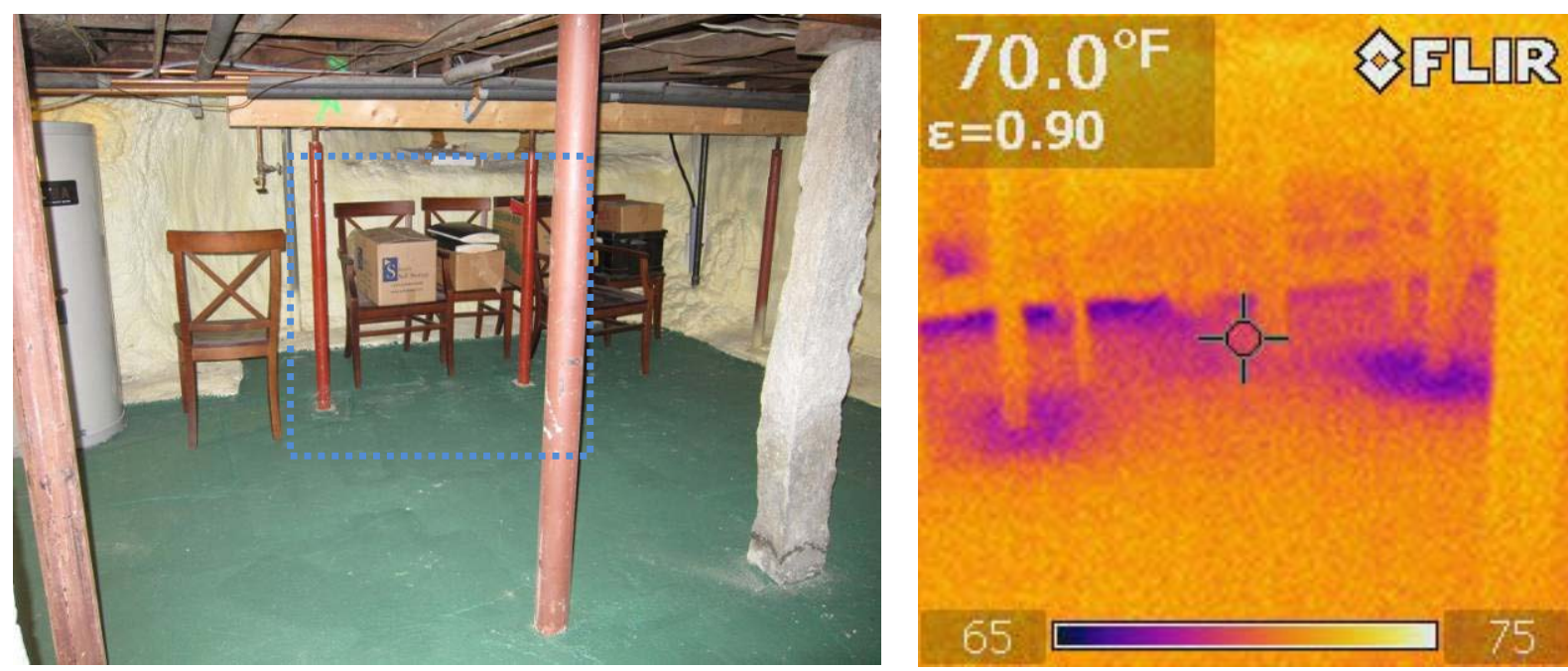

Figure 55. Slab temperature at footing penetrations, Westford Barn/House

For reference, the sump pit area temperature was checked with an infrared camera to determine the earth temperature under the slab insulation. It was typically in the $60^{\circ} \mathrm{F} / 16^{\circ} \mathrm{C}$ range, as shown in Table 7. A colder, uninsulated slab (closer to $60^{\circ} \mathrm{F} / 16^{\circ} \mathrm{C}$ ) would have greater chance of condensation issues.
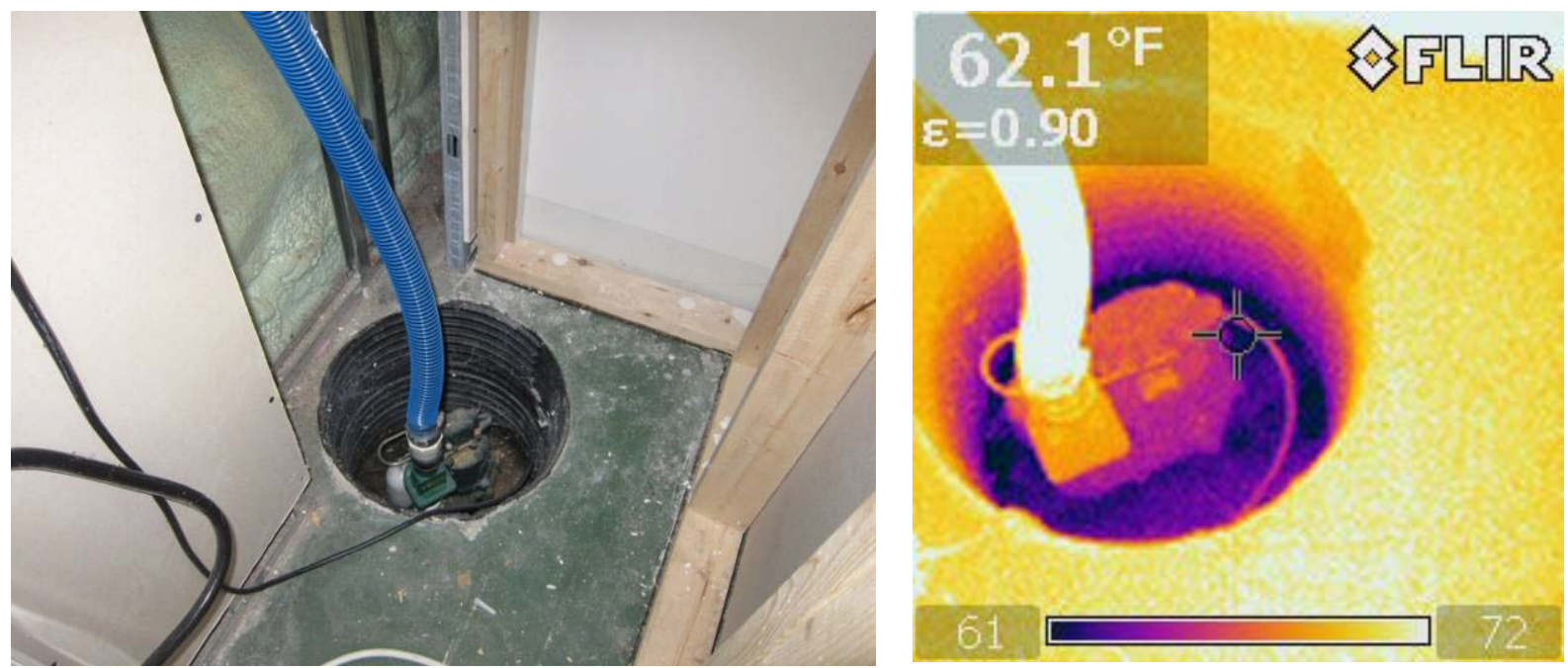

Figure 56. Sump pit temperatures, Concord House

Energy simulations typically indicate that there are minimal energy savings associated with insulation of basement slabs, due to the relatively stable earth temperatures and the effective insulating value of the soil surrounding the basement. However, insulating the basement slab has benefits for moisture control and IAQ issues, by removing the cold (potentially condensing) surface.

One common problem in basements is the use of carpeting directly on an uninsulated slab: the carpet acts as insulation, cooling the slab beneath. The area under the carpet is at the same dewpoint as the basement, but at a lower temperature: this effect results in high humidities under the carpet, and the potential for mold growth. However, conditions under carpets were checked at these insulated slabs: there was a minimal temperature difference associated with the carpeted 
areas (Figure 57). This is because the majority of the temperature drop occurs across the sub-slab insulation, and carpeting is minimal insulation in comparison.
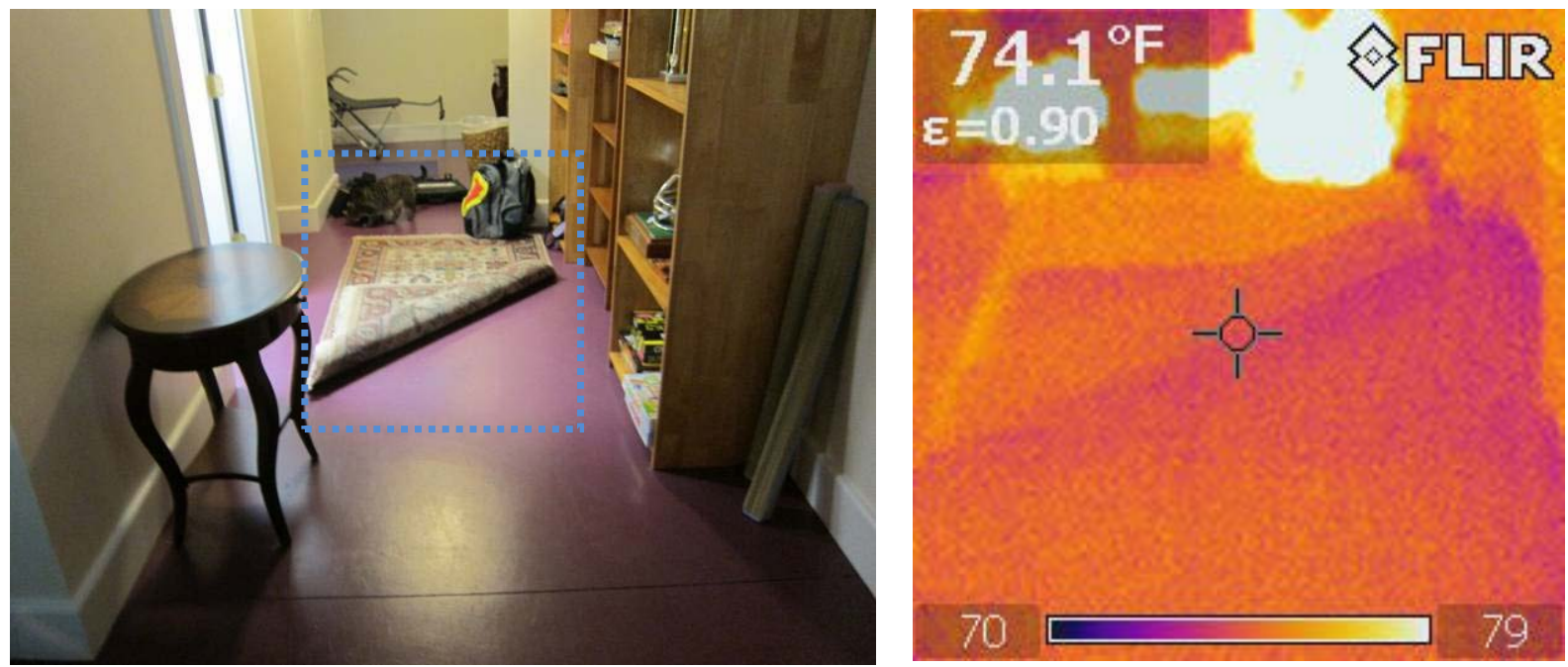

Figure 57. Slab temperature underneath carpet, Concord House

Similarly, cardboard boxes often suffer problems when stored on basement slabs due to this insulating effect, as well as the potential to trap capillary moisture underneath. As shown in Figure 58, the temperature difference is minimal $\left(75^{\circ} \mathrm{F} / 24^{\circ} \mathrm{C}\right.$ main floor temperature; $73^{\circ}$ $\mathrm{F} / 23^{\circ} \mathrm{C}$ underneath box).
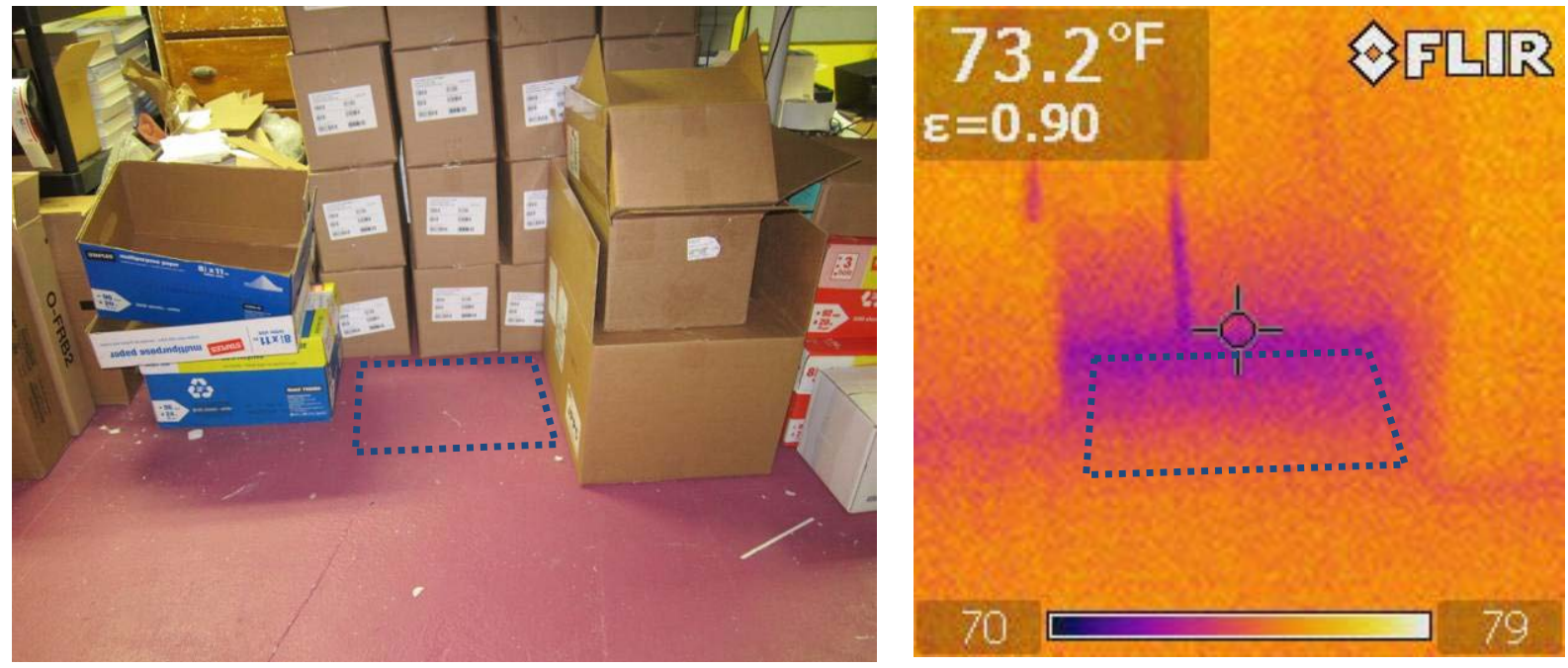

Figure 58. Slab temperatures under filled cardboard box, Somerville Office

\subsubsection{Sill Beam}

As discussed previously, the sill beam has the potential for moisture damage with these retrofit designs, due to reduced drying to the interior from the application of interior closed cell spray foam. Therefore, the moisture content of the sill beam was tested, where it was accessible.

Moisture contents were uniformly in the safe range, typically in the $8 \%-13 \%$ range, similar to the moisture content measured at interior framing members (floor joists). 

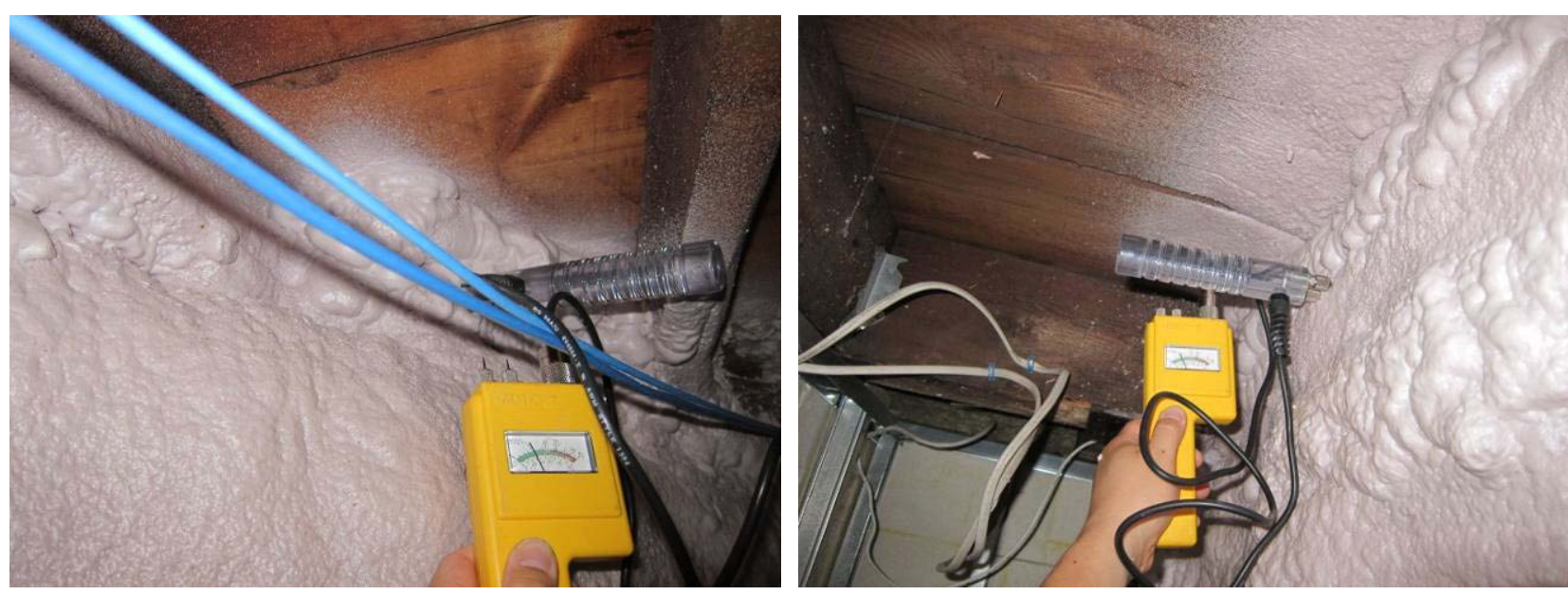

Figure 59. Sill beam moisture content measurement, Somerville Office

Admittedly, this is a spatially limited survey, and the moisture content of the interior side of the beam is unlikely to show damage. In addition, the moisture content of the beam would vary seasonally; these measurements were taken during the July field survey. Overall, long term monitoring of wood moisture contents would be the most useful approach to examine this question in greater detail.

\subsection{Critical Takeaways}

The relative humidity behind the ccSPF was high in all cases; therefore, an air barrier between that layer and the interior is critical.

The dewpoint of air (and thus absolute moisture content) is tied to its temperature. For most below-grade cases, the walls are relatively cool, so the dewpoint is low: therefore, the inward moisture vapor drive is relatively low.

The ccSPF layer functions as the air barrier. A rubble wall is not an acceptable air barrier without additional detailing (e.g., parging).

There was no sign of any damage due to exterior masonry freeze-thaw issues, or frost heaving.

There was no indication of moisture erosion damage, albeit with a limited survey.

There was no indication of high moisture content in the sill beam, albeit with a limited survey.

Insulation of a basement slab essentially eliminates the moisture risks experienced with carpeting on slabs or storage of boxes. 


\section{Field Monitoring}

\subsection{Field Monitoring Site}

One component of this project is the field monitoring of a basement insulated with interior closed cell spray foam in 2008. The test house (Figure 60) is located in St. Agatha, Ontario ( 75 miles/120 km west of Toronto, DOE Zone 6 Climate), and was insulated as a step of a deep energy retrofit project. The existing basement did not have any bulk water leakage issues; therefore, extensive drainage measures (interior drainage, etc.) were not installed. The basement wall is concrete block with an interior finish parge coat. Closed cell spray foam was chosen over board foam (despite the flatness of the wall), because ccSPF was available at the same cost, and because ccSPF has superior installed airtightness.
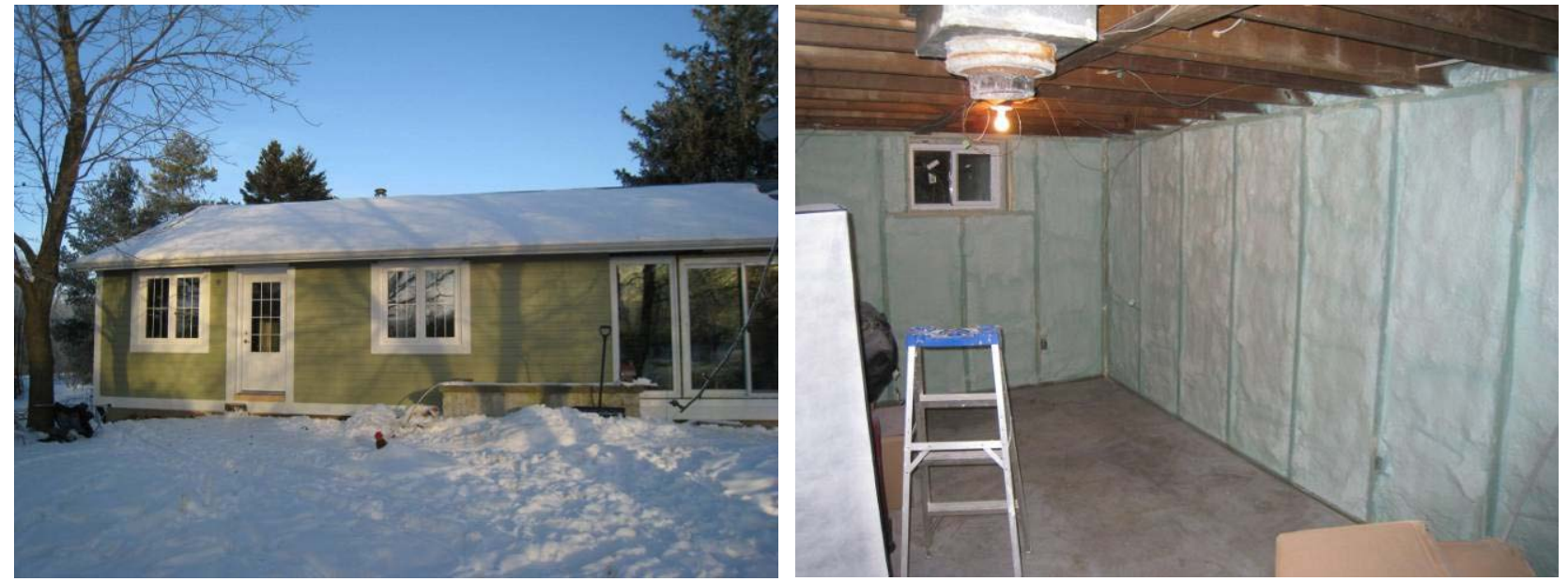

Figure 60. Exterior view of St. Agatha site; completed basement ccSPF retrofit
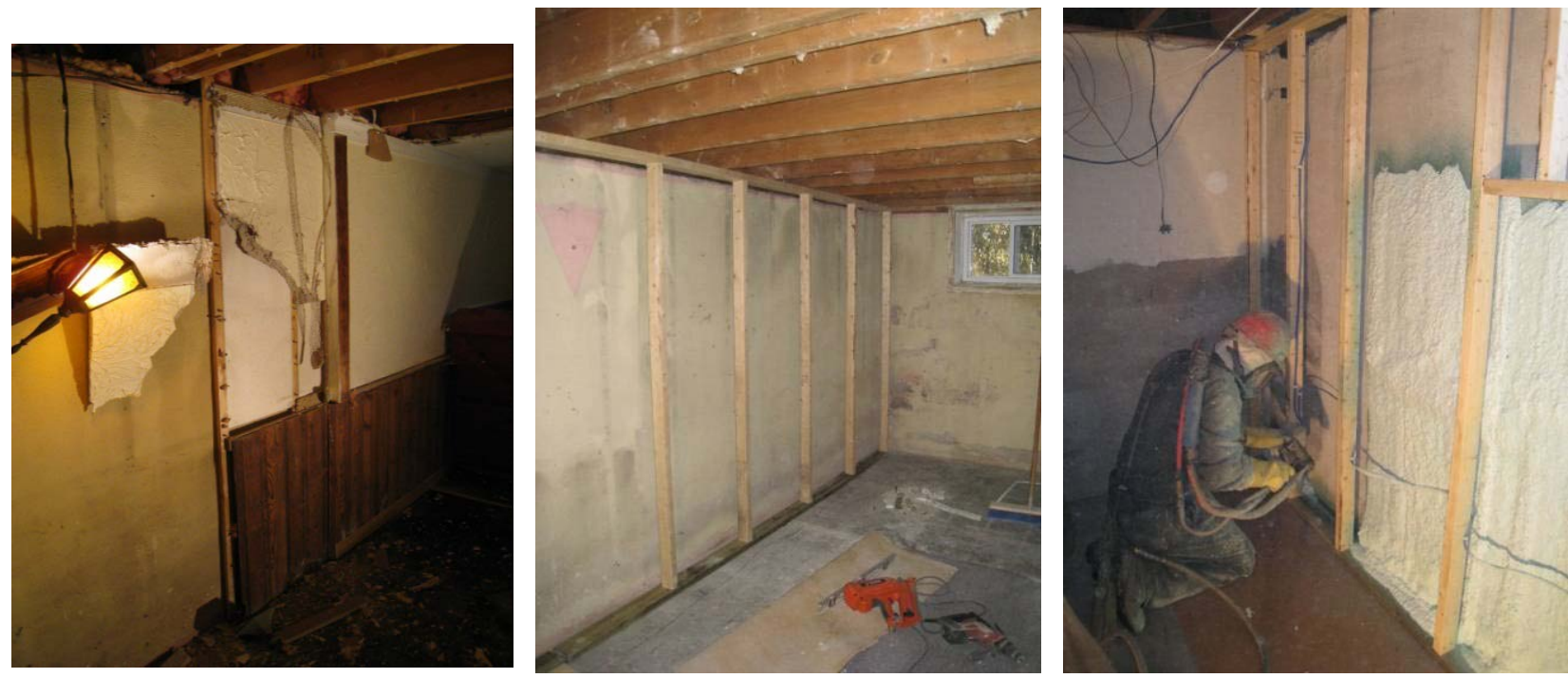

Figure 61. ( $L$ to $R$ ) Pre-retrofit basement; interior framing; spray foam application

Instrumentation was installed during construction: temperature sensors were installed at the rim joist, and at the insulation-to-concrete interface layer, at several heights (high, middle low). In addition, wood wafers with moisture content measurement pins were also installed at these 
locations, as a surrogate measurement for relative humidity (see Ueno 2008). Data is currently being collected, and is to be analyzed.
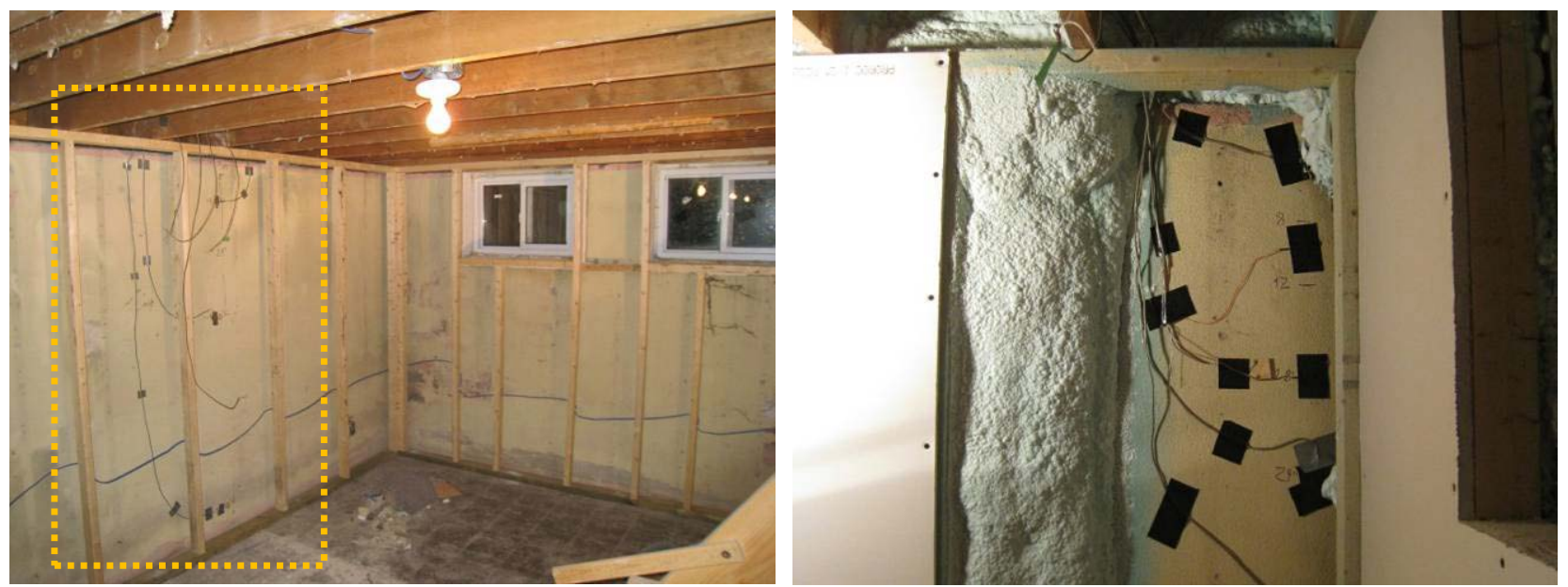

Figure 62. Overview and close-up of instrumentation in ccSPF retrofit basement

One phenomenon noted was the vertical wicking of heat from the earth around the foundation, up into the foundation wall. This is shown in infrared images (Figure 63) taken in February 2011, showing relatively warm surface temperatures of the foundation wall. Air temperatures around the time of these images ranged from a low of $-8^{\circ} \mathrm{F}\left(-22^{\circ} \mathrm{C}\right)$ overnight to a high of $23^{\circ} \mathrm{F}\left(-5^{\circ} \mathrm{C}\right)$ in the afternoon. The above-grade wall is insulated to R-40/RSI 7.0 and the foundation to over R25/RSI 4.4: analysis indicates that these differences cannot simply be explained by R-value differences, thermal mass effects, or solar exposure.
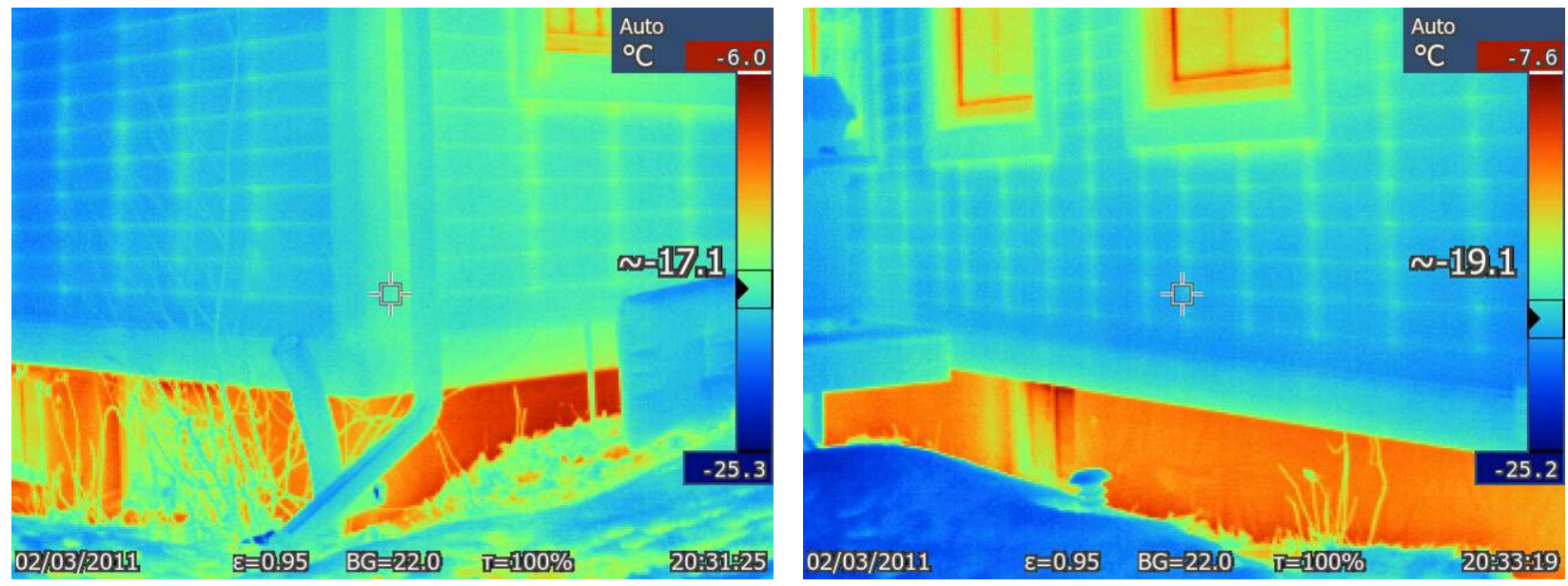

Figure 63. Infrared images of basement wall in wintertime (February) conditions

\subsection{Comparison Data}

The observations of warm foundation wall temperatures, as found at this monitoring location, were also noted in previous research on interior foundation insulation (Ueno 2007). Temperature sensors were installed at the insulation-concrete interface at various heights of the wall (see Figure 64), and extensive data were collected. 


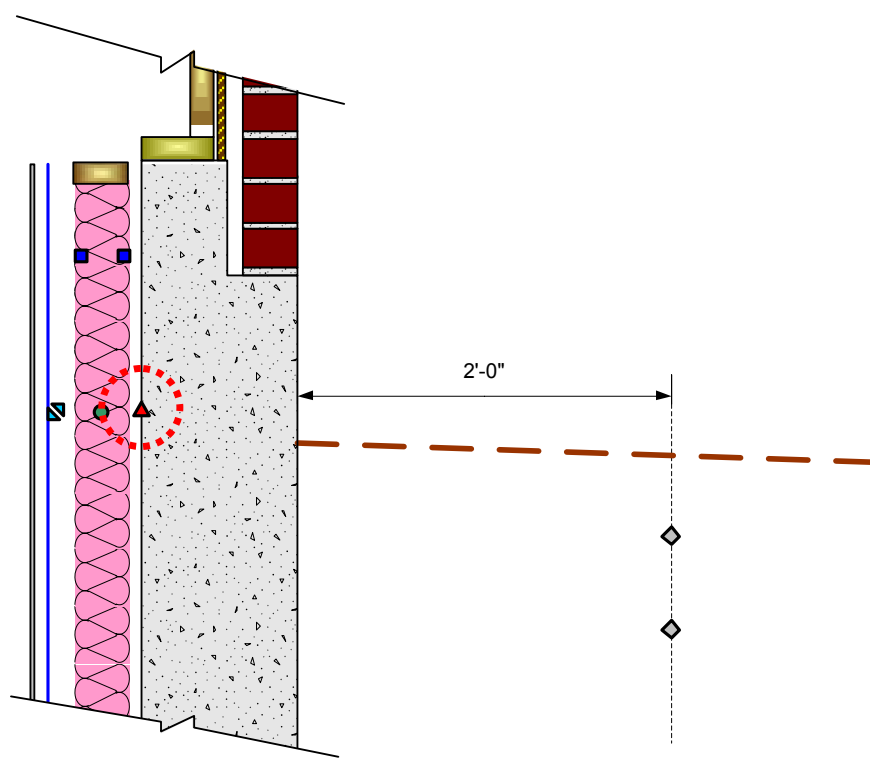

Figure 64. Sensor locations and types in basement wall monitoring (Ueno 2007)

The collected data was compared to one-dimensional hygrothermal simulations using recorded weather data and appropriate material properties. The model showed a lack of temperature correspondence, especially in the winter, as shown in the plot of the temperature (and dewpoint) at the concrete-insulation interface (Figure 65). The model predicts interface temperatures that drop to $19^{\circ} \mathrm{F} /-7^{\circ} \mathrm{C}$, while measured data is substantially warmer, with minimums of $28^{\circ} \mathrm{F} /-2^{\circ} \mathrm{C}$.

One initial theory to explain the difference was that the R-values of the assembly components were not correct; for instance, that the insulation was wet or compacted (lower R-value), or the concrete was dryer than simulated (higher R-value). However, a plot of the concrete $\Delta \mathrm{T}$ vs. the total $\Delta \mathrm{T}$ showed a contribution of $20-30 \%$ for the concrete, compared to the calculated $3 \%-6 \%$. This is far too large to be explained by insulation value differences.

The soil temperature at $6 " / 150 \mathrm{~mm}$ was then compared with the monitored interface temperature, which provided a closer match than exterior air temperature. It seems likely that two-dimensional effects, which cannot be captured in a one-dimensional simulation, such as heat flow to/from the soil, are dominating the above-grade portion of the wall. Since the temperature sensor is roughly at grade level, the above-grade and below-grade environments both have an effect. The details at the rim joist, such as the brick ledge and the transition to the insulated wooden framing, result in further thermal anomalies. Finally, the aspect ratio of the wall at this location does not favor a one-dimensional simplification: only a small portion of this wall is reflected by the onedimensional simplification, so thermal flanking seems quite possible. 


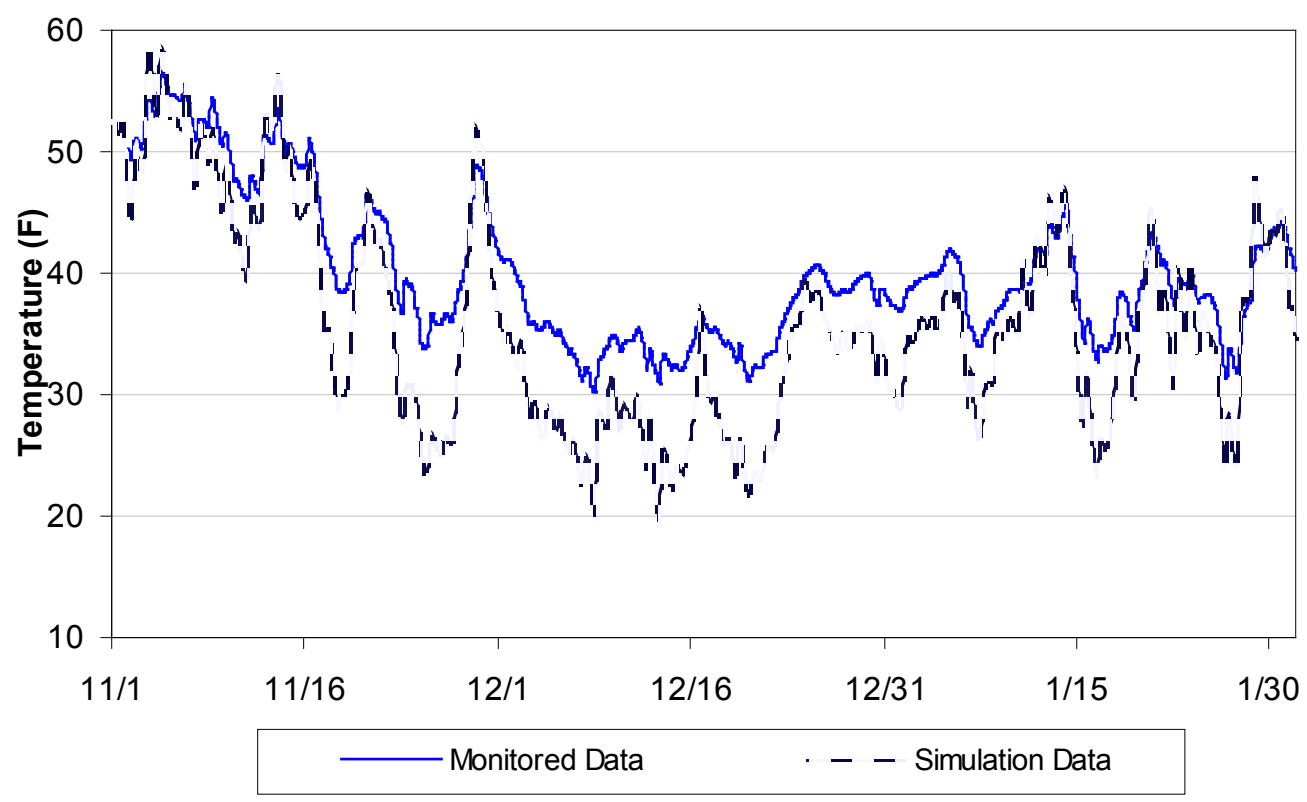

Figure 65. Concrete-insulation interface temperature, monitored vs. simulation (Ueno 2007)

One impact of the observed warmer foundation wall temperatures is that interior vapor control of the above-grade portion of the foundation wall might be less important than previously believed, due to the warmer condensing surface temperature. 


\section{Conclusions and Further Work}

The use of closed cell spray foam as a method of damp foundation repair can be "leveraged" to provide energy efficiency benefits. Correctly installed, this retrofit provides basement insulation and bulk water control, acting as a "hybrid" assembly. This method should be considered an effective and mature technology, with an extensive track record in a variety of installations. There are many design variations that can be chosen based on existing conditions (foundation wall, degree of bulk water problems), budget, desired finished appearance, use of the basement space, and risk tolerance.

There are thousands of implementations of various types of these systems, without reports of endemic failures. It is reasonable to consider this system ready for mass implementation in retrofit projects.

However, several topics warrant further research to positively address potential durability concerns, and/or determine the level of remedial measures required when performing this retrofit. They include:

Frost heave due to the interior retrofit insulation of foundations (due to the reduced heat flow to the exterior) in very cold climates (DOE Zone 6 and 7) has not been conclusively proven or disproven as a significant risk. Additional study is warranted, including the effectiveness of remedial measures such as exterior "wing" insulation and/or addition of exterior drainage to prevent saturation of exterior soils.

The determination of whether a basement is "sufficiently historically dry" to forgo the use of a drainage layer is a matter of judgment and evaluation of site conditions. More rigorous guidelines for making this decision could be valuable.

Some foundation walls show efflorescence, spalling, and masonry erosion damage in their existing state. Retrofit insulation with ccSPF should reduce the rate of damage; however, confirmation of this phenomenon and examination of moisture behavior would be valuable to ascertain that this retrofit completely addresses these issues.

There are durability concerns associated with the use of spray foam at the sill beam/rim joist. The beam is colder (and therefore wetter) than its pre-retrofit condition and energy and airflow are not available to assist in drying. In addition, the use of low-permeability ccSPF on the interior greatly reduces drying to the interior. Given that damage is often seen in sill beams in pre-retrofit conditions, further study is recommended to better understand the relative contributions of various risk factors, and the effectiveness of mitigation techniques. Field monitoring of insulated sill beams could be a worthwhile exercise in this research.

Two dimensional heat flow effects through foundations appear to be significant, which could influence durability and condensation risk issues. 


\section{References}

Anderson, S. (December 2005). "Foolproof Cure for Wet Basements." Journal of Light Construction. Washington, DC: Hanley Wood, LLC.

[ASHRAE] American Society of Heating, Refrigerating and Air-Conditioning Engineers (2009). 2009 ASHRAE Handbook-Fundamentals. Atlanta, GA: American Society of Heating, Refrigeration, and Air-Conditioning Engineers, Inc.

Beausoleil-Morrison, I., G. Mitalas. (1997). BASESIMP: A Residential-Foundation Heat-Loss Algorithm For Incorporating Into Whole-Building Energy-Analysis Programs. Proceedings of Building Simulation '97, Volume 2: 1-8.

[BETT] Building Energy Technology Transfer. (1985a). Assessing the Rehabilitation Needs of Foundations: A Research Report ("A Literature Review on Foundation Problems and a Draft Diagnostic Guide for Basement Retrofit Contractors”), Publication No. 85.02, Energy Conservation and Oil Substitution Branch, Energy, Mines, and Resources Canada.

[BETT] Building Energy Technology Transfer. (1985b). Effects of Insulation on Basement Walls: A Research Report ("A Survey of the Statistical Incidence of Problems, Together with an Evaluation of the Technical Processes”), Publication No. 85.03, Energy Conservation and Oil Substitution Branch, Energy, Mines, and Resources Canada.

Ueno, K and J. Lstiburek. (2010). Research Report 1015: Bulk Water Control Methods for Foundations. Building Science Corporation, Westford, MA. http://www.buildingscience.com/ documents/reports/rr-1015-bulk-water-control-methods-for-foundations/

Building Envelope Services, Inc. (2008). "The BES/FOAM-TECH AVID System (Air/Vapor/ Insulation/Drainage)." http://www.foam-tech.com/special/avid.htm. North Thetford, VT: Building Envelope Services, Inc.

Carmody, J. Christian, J., Labs, K. (1991). “Builder’s Foundation Handbook.” Report to Oak Ridge National Laboratory ORNL/CON-295, Oak Ridge, TN.

Cheple, M. and Huelman, P. (2001). "Why we need to know more about basement moisture." Thermal Performance of the Exterior Envelopes of Whole Buildings VIII. Atlanta, GA: American Society of Heating, Refrigeration, and Air-Conditioning Engineers, Inc.

Crocker, C.R. (1974). NRC-IRC (Institute for Research in Construction) Canadian Building Digest CBD-161. "Moisture and Thermal Considerations in Basement Walls," Ottawa, ON: National Research Council of Canada.

[EDU] Energy Design Update (November 2009) "New Fire-Resistance Standard for Attic and Crawl Space Foam.” New York, NY: Aspen Publishers.

Genge, Colin. (April 2009). "Controlling Air Leakage in Tall Buildings.” ASHRAE Journal (vol. 51); pp. 50-60. Atlanta, GA: American Society of Heating, Refrigeration, and Air-Conditioning Engineers, Inc. 
Goldberg, L. and Farkas, G. (2004). Icynene Foundation Insulation Project, Available online: http://www.buildingfoundation.umn.edu/IcynenFinalReport/default.htm. Minneapolis-St. Paul, MN: University of Minnesota.

Hales, D. M. Lubliner, A. Gordon. (2010) "Vented and Conditioned Crawlspace Performance in Marine and Cold Climates of the Pacific Northwest." Performance of the Exterior Envelopes of Whole Buildings XI. Atlanta, GA: American Society of Heating, Refrigeration, and AirConditioning Engineers, Inc.

Hutcheon, N.B. and Handegord, G.O. (1995). Building Science for a Cold Climate. Ottawa, ON: National Research Council of Canada.

[ICC] International Code Council, (2009). 2009 International Residential Code for One- and Two-Family Dwellings, Country Club Hills, IL: International Code Council, Inc.

Janesky, L. (June 2001). “Keeping a Basement Dry.” Fine Homebuilding Magazine. Newtown, CT: Taunton Press.

Künzel, H. (2010). WUFI® PC-Program for calculating the coupled heat and moisture transfer in buildings. Fraunhofer Institute for Building Physics. Holzkirchen, Germany.

Lauten, R. (September 2009). “Drying a Stone Cellar.” Journal of Light Construction. Washington, DC: Hanley Wood, LLC.

[LBNL] Lawrence Berkeley National Laboratory. 2003. THERM 5.2: A PC Program for Analyzing Two-Dimensional Heat Transfer Through Building Products. Building Technologies Department, Environmental Energy Technologies Division, Ernest Orlando Lawrence Berkeley National Laboratory, Berkeley CA.

Lstiburek, J.W. (July 2006). "Understanding Basements.” ASHRAE Journal (vol. 48); pp. 24-29. Atlanta, GA: American Society of Heating, Refrigeration, and Air-Conditioning Engineers, Inc.

Lstiburek, J.W. (July 2007). "Building Sciences: Capillarity-Small Sacrifices.” ASHRAE Journal (vol. 49); pp. 58-61.

Lstiburek, J.W. (May 2008). "Building Sciences: New Light in Crawl Spaces.” ASHRAE Journal (vol. 50); pp. 66-74.

Lstiburek, J.W. (March 2010a). "Building Sciences: Rubble Foundations." ASHRAE Journal (vol. 52); pp. 72-78. Atlanta, GA: American Society of Heating, Refrigeration, and AirConditioning Engineers, Inc.

Lstiburek, J.W. (April 2010b). "Building Sciences: Double Rubble Toil \& Trouble.” ASHRAE Journal (vol. 52); pp. 54-58. Atlanta, GA: American Society of Heating, Refrigeration, and AirConditioning Engineers, Inc. 
Lstiburek, J.W. (October 2011). "Building Sciences: Leiningen Versus The Ants Redux." ASHRAE Journal (vol. 53); pp. 74-82. Atlanta, GA: American Society of Heating, Refrigeration, and Air-Conditioning Engineers, Inc.

Pettit, B. (April/May 2008) "Remodeling for Energy Efficiency." Fine Homebuilding Magazine. Newtown, CT: Taunton Press.

Penner, E. (1962). NRC-IRC (Institute for Research in Construction) Canadian Building Digest CBD-26. "Ground Freezing and Frost Heaving." Ottawa, ON: National Research Council of Canada.

Pindell, M. (January 2010). "Insulating a Slab with Spray Foam.” Journal of Light Construction. Washington, DC: Hanley Wood, LLC.

Pressnail, K.D. and Timusk, J. (1987). “Adfreezing of Insulated Residential Basements: An Hypothesis.” Canadian Journal of Civil Engineering, Volume 14, pp. 708-710.

Straube, J.F., and Burnett, E.F.P., (2005). Building Science for Building Enclosure Design, Building Science Press: Westford, MA.

Straube, J.F., K. Ueno, and C.J. Schumacher (2011). Research Report 1105: Internal Insulation of Masonry Walls: Final Measure Guideline. Building Science Corporation, Westford, MA. http:/www.buildingscience.com/documents/reports/rr-1105-internal-insulation-masonry-wallsfinal-measure-guideline/

Swinton, M., Bomberg, M, Kumaran, M.K., Maref, W., Normandin, N., Marchand, R.G. (2000). "In-Situ Performance Evaluation of Exterior Insulation Basement System (EIBS) - Spray Polyurethane Foam.” Internal Report No. 820. Ottawa, ON: Institute for Research in Construction/National Research Council Canada.

Swinton, M. and Kesik, T. (2005). "Performance Guidelines for Basement Envelope Systems and Materials: Final Research Report." B1018.1. Ottawa, ON: Institute for Research in Construction/National Research Council Canada, 193 pp.

Tooley, J. (October 2003). "Building a Sealed Crawlspace.” Journal of Light Construction. Washington, DC: Hanley Wood, LLC.

Tooley, J. (August 2004). “Fixing a Wet Crawlspace.” Journal of Light Construction. Washington, DC: Hanley Wood, LLC.

Ueno, K. and Townsend, A. (2006) "Field Monitoring of the Hygrothermal Performance of Interior Basement Insulation Systems," ACEEE Summer Study on Energy Efficiency in Buildings, August 2006. Washington, DC: American Council for an Energy-Efficient Economy.

Ueno, K. and Straube, J.F. (2007). "Field Monitoring and Hygrothermal Modeling of Interior Basement Insulation Systems.” Performance of the Exterior Envelopes of Whole Buildings X. Atlanta, GA: American Society of Heating, Refrigeration, and Air-Conditioning Engineers, Inc. 
Ueno, K., and Straube J. (2008) "Laboratory Calibration and Field Results of Wood Resistance Humidity Sensors", Proceedings of BEST 1 Conference, Minneapolis, June 10-12, 2008.

Ueno, K. (2010). "Residential Exterior Wall Superinsulation Retrofit Details and Analysis." Performance of the Exterior Envelopes of Whole Buildings XI. Atlanta, GA: American Society of Heating, Refrigeration, and Air-Conditioning Engineers, Inc.

Zuluaga, Marc, Robb Aldrich, and Dianne Griffiths. (2004). "Field Performance of Different Interior Basement Insulation Systems." Performance of the Exterior Envelopes of Whole Buildings IX. Atlanta, GA: American Society of Heating, Refrigeration, and Air-Conditioning Engineers, Inc. 


\section{U.S. DEPARTMENT OF Energy Efficiency \& ENERCY Renewable Energy}

